\title{
U.S. GEOLOGICAL SURVEY \\ WATER RESOURCES ACTIVITIES IN FLORIDA, 1985-86
}

By Mildred E. Glenn, editor

U.S. GEOLOGICAL SURVEY

Open-File Report $86-150$
IN COOPERATION WITH

Florida Dept. of Environmental Regulation

Florida Dept. of Natural Resources

Florida Dept. of Transportation

Northwest Florida Water Management District

St. Johns River Water Management District

South Florida Water Management District

Southwest Florida Water Management District

Suwannee River Water Management District

Englewood Water District

Joshua Water Control District

Old Plantation Water Management District

Pinellas Park Water Management District

South Dade Soil \& Conservation Water District

Reedy Creek Improvement District

Collier Mosquito Control District

Florida Keys Aqueduct Authority

Jacksonville Electric Authority

Miami-Dade Water \& Sewer Authority

Palm Beach county Solid Waste Authority

Suwannee River Authority

West Coast Regional Water Supply Authority

Big Cypress Basin Board

Florida Institute of Phosphate Research

Division of Marine Research, DNR

Broward County

Broward County Environ. Quality Control Board

Broward County Waste \& Waste Water Division

Dade County

Escambia County Utilities Authority

Franklin County

Hernando County

Hillsborough County

Indian River County

Lake County

Lee County
Leon County

Manatee County

Palm Beach County

Pasco County

Pinellas County

Polk County

St. Johns County

Sarasota County

Sumter County

Walton County

City of Boca Raton

City of Bradenton

City of Cape Coral

City of Clearwater

City of Cocoa

City of Daytona Beach

City of Fort Lauderdale

City of Hallandale

City of Hollywood

City of Jacksonville

City of Perry

City of Pompano Beach

City of Port Orange

City of Quincy

City of Sanibel

City of Sarasota

City of Stuart

City of Tallahassee

City of Tampa

Town of Highland Beach

University of Central Fla.

University of South Fla.

National Park Service

U.S. Air Force

U.S. Corps of Engineers 
UNITED STATES DEPARTMENT OF THE INIEERIOR

DONAWD PAUL HODEL, Secretary

GEOLOGICAL SURVEY

Dallas L. Peck, Director

Eoa additional, information write to:

District Chief

U.S. Geological Survey

Suite 3015 :

int

227 North Bronough. Street

Tallahassee, Floridain, 2301
Copies of this report can be purchased from:

Open-File Services Section Western Distribution Branch U.S. Geological Survey Box 25425, Federal Center Denver, Colorado 80225

(Telephone: (303) 236-7476) 


\section{U.S. GEOLOGICAL SURVEY OFFICES IN FLORIDA}

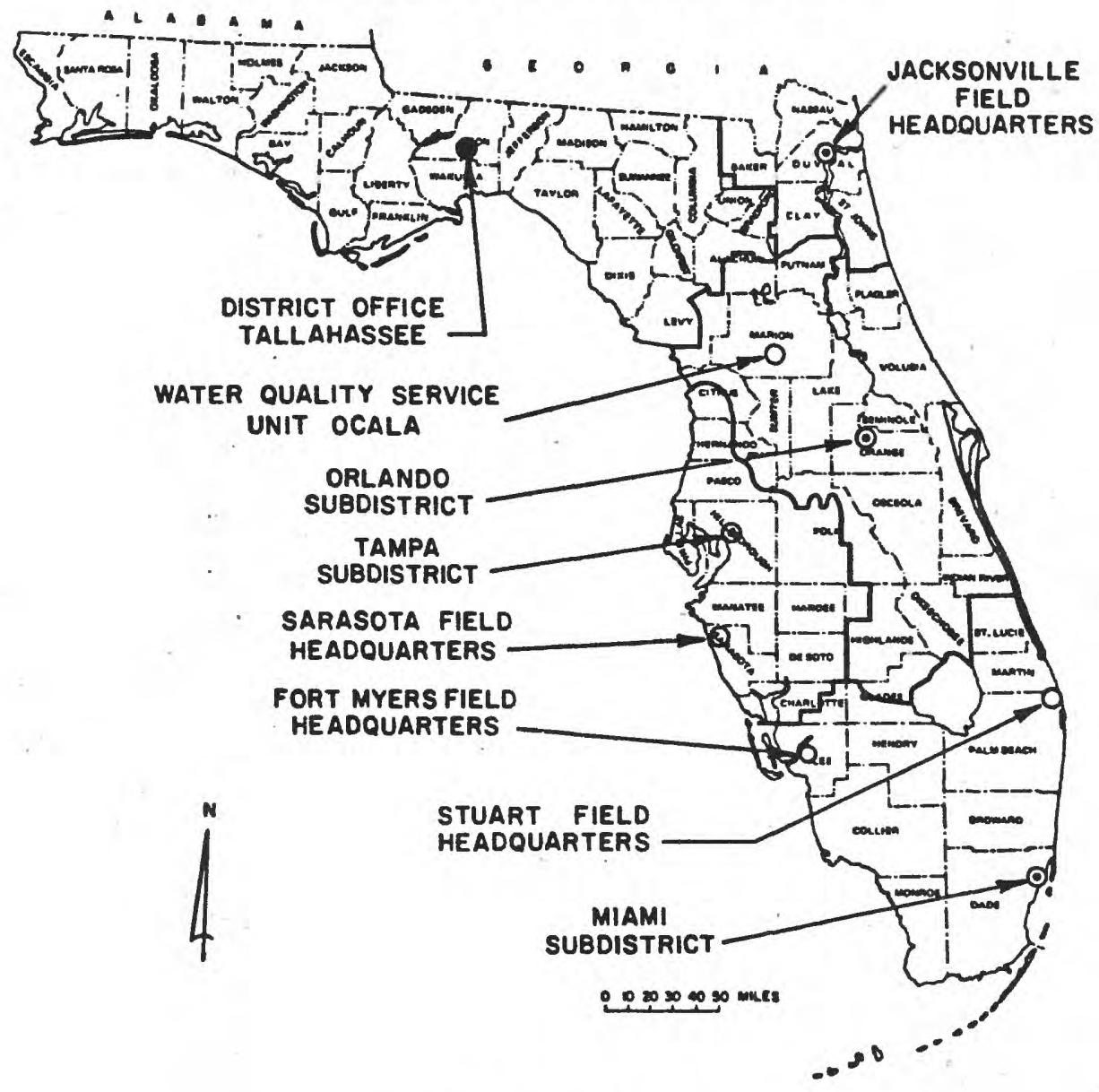

District Office

Suite 3015, $227 \mathrm{~N}$. Bronough Street

Tallahassee, FL 32301

Telephone: (904) 681-7620

Miami Subdistrict Office

P.O. Box 026052

Miami, FL 33102

Telephone: (305) 594-0655

Orlando Subdistrict Office

80 North Hughey Avenue, Suite 216

Orlando, FL 32801

Telephone: (305) 420-6191

Tampa Subdistrict Office

4710 Eisenhower Blvd., Suite B-5

Tampa, FL 33614

Telephone: (813) 228-2124

Ocala ow Service Unit

207 NW 2nd Street, Room 240

Ocala, FL 32670

Telephone: (904) 629-8931
Fort Myers Field Headquarters Federal Bldg., First St., Rm 307 Fort Myers, FL 33901

Telephone: (813) 334-7787

Jacksonville Field Headquarters

1851 Executive Center Drive

Jacksonville, FL 32207

Telephone: (904) 398-2121

Sarasota Field Headquarters

3110 University Parkway

Sarasota, FL 33580

Telephone: (813) 355-6552

Stuart Field Headquarters

6482 SE Federal Highway

Stuart, FL 33494

Telephone: (305) 286-6299 


\section{FOREWORD}

The U.S. Geological Survey was created by Act of Congress in 1879, as a bureau of the Department of the Interior, to classify public lands and to examine the geologic structure, mineral resources, and products of the national domain. Since then, the Survey's responsibilities have expanded to include topographic mapping, geochemical and geophysical studies, and the assessment of the quantity, quality, and distribution of water resources. Thus, during the past 100 years, the survey has become the Nation's principal factfinding and research agency concerned with our physical resources. The mission of the Water Resources Division of the Survey is to provide hydrologic information needed for the development, management, and use of the Nation's water resources.

Although stream gaging began in 1884 as part of a study to identify irrigatable land, the water-resources program of the Survey began in 1894 when a small appropriation was obtained for the specific purpose of "gauging streams and determining the water supply of the United States." In the years following 1884, the need for water resources information grew rapidly but the inability of the Survey to meet the demand was hampered by restricted budgets. Many states initiated water resource programs to fill the deficiency and the Survey worked closely with the various state agencies. However, these efforts did not satisfy the need of the states and the Nation for a comprehensive water resources information program. Accordingly, Congress, in 1928, established the cooperative matching program by which the Survey's water resources programs with state agencies may be funded on a $50 / 50$ basis. This cooperative water resources program has grown over the years into the primary source of water information for the Nation. In cooperation with state and local governments and other Federal agencies, the Water Resources Division --

- Collects data on a systematic basis to determine the quantity, quality, and use of surface and ground water.

- Conducts interpretive water-resource appraisals to describe the consequences of alternative plans for developing land and water resources.

- Conducts basic and problem-oriented research in hydraulics, hydrology, and related fields.

- Develops information on water-related natural hazards such as floods, landslides, volcanoes, mudflows, and land subsidence.

- Coordinates the activities of all Federal agencies in the acquisition of water data.

- Disseminates data and findings through reports, maps, and other forms of public release.

- Provides scientific and technical assistance in the hydrologic fields to other Federal agencies, to State and local agencies, and, on behalf of the U.S. Department of State, to international agencies.

Water Resources, National Mapping, and Geologic Divisions are the three operating Divisions of the Survey. General information pertaining to these divisions may be obtained from the Information Office, U.S. Geological Survey, 119 National Center, Reston, VA 22092. Circular 777, "A Guide to Obtaining Information from the U.S. Geological Survey" can be obtained free from the Branch of Distribution, U.S. Geological Survey, 604 South Pickett Street, Alexandria, VA 22304. 


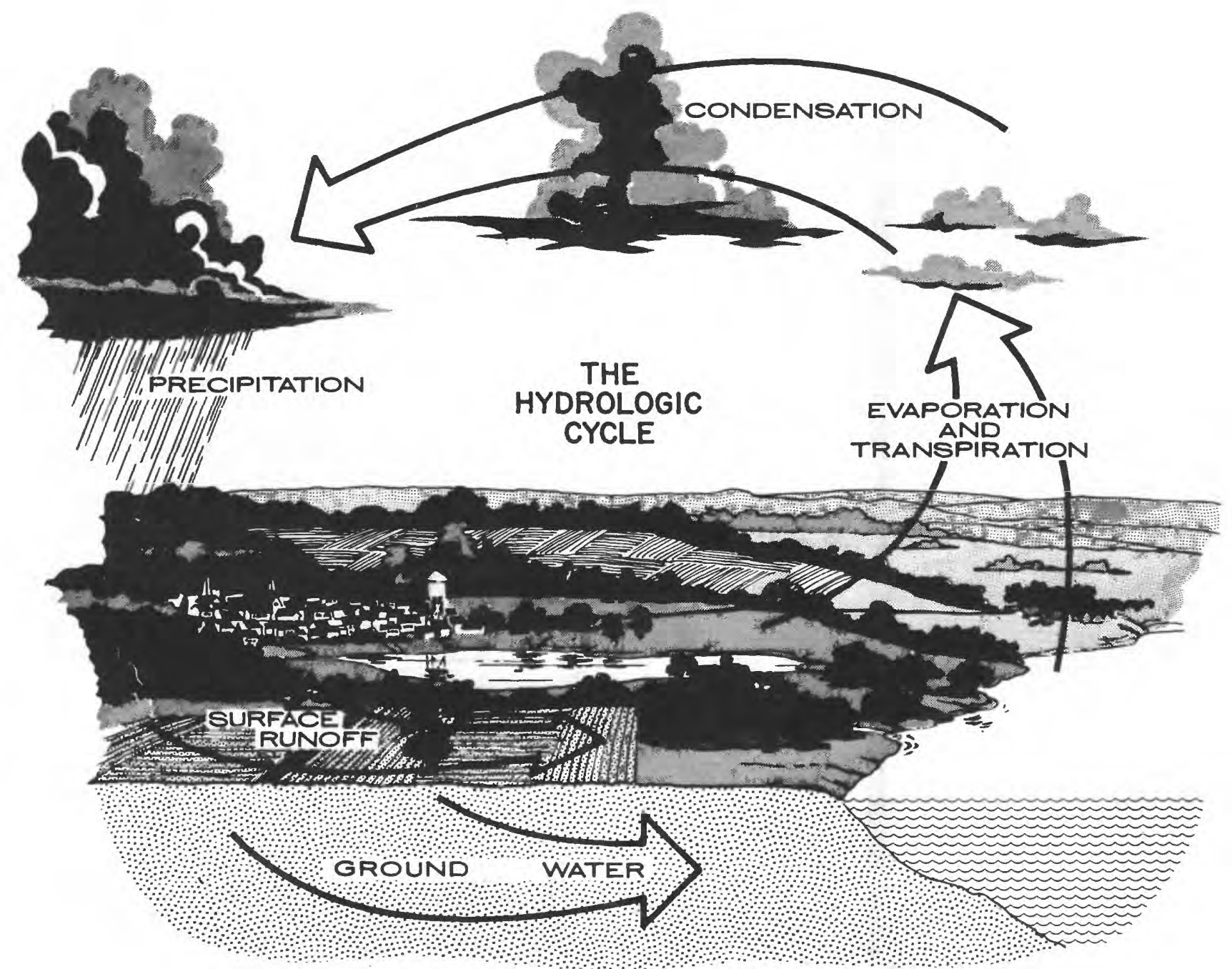




\section{CONTENTS}

Page

Foreword......................................... III

Introduction $\ldots \ldots \ldots \ldots \ldots \ldots \ldots \ldots \ldots \ldots \ldots \ldots \ldots \ldots \ldots \ldots \ldots$

U.S. Geological Survey Water Resources Division programs........ 3

National Water-Data Exchange (NAWDEX).................... 4

National Water-Data Storage and Retrieval System (WATSTORE)...... 5

Distributed Information System (DIS) $\ldots \ldots \ldots \ldots \ldots \ldots \ldots \ldots \ldots \ldots$

National Stream Quality Accounting Network (NASQAN) ............ 7

New reports from the U.S. Geological Survey, Florida District..... 9

How to obtain reports prepared by the Florida District......... 13

Florida Water Resources Research Center.................... 14

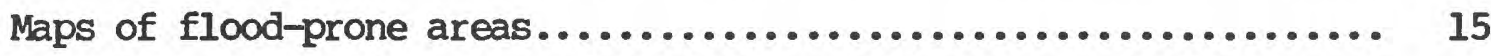

Location and areal investigations and the five water

management districts............................. 16

Water resources activities in Florida, 1985-86............. 17

Summaries of Florida water-resources activities.............. 20 


\section{COMPETITION FOR WATER}

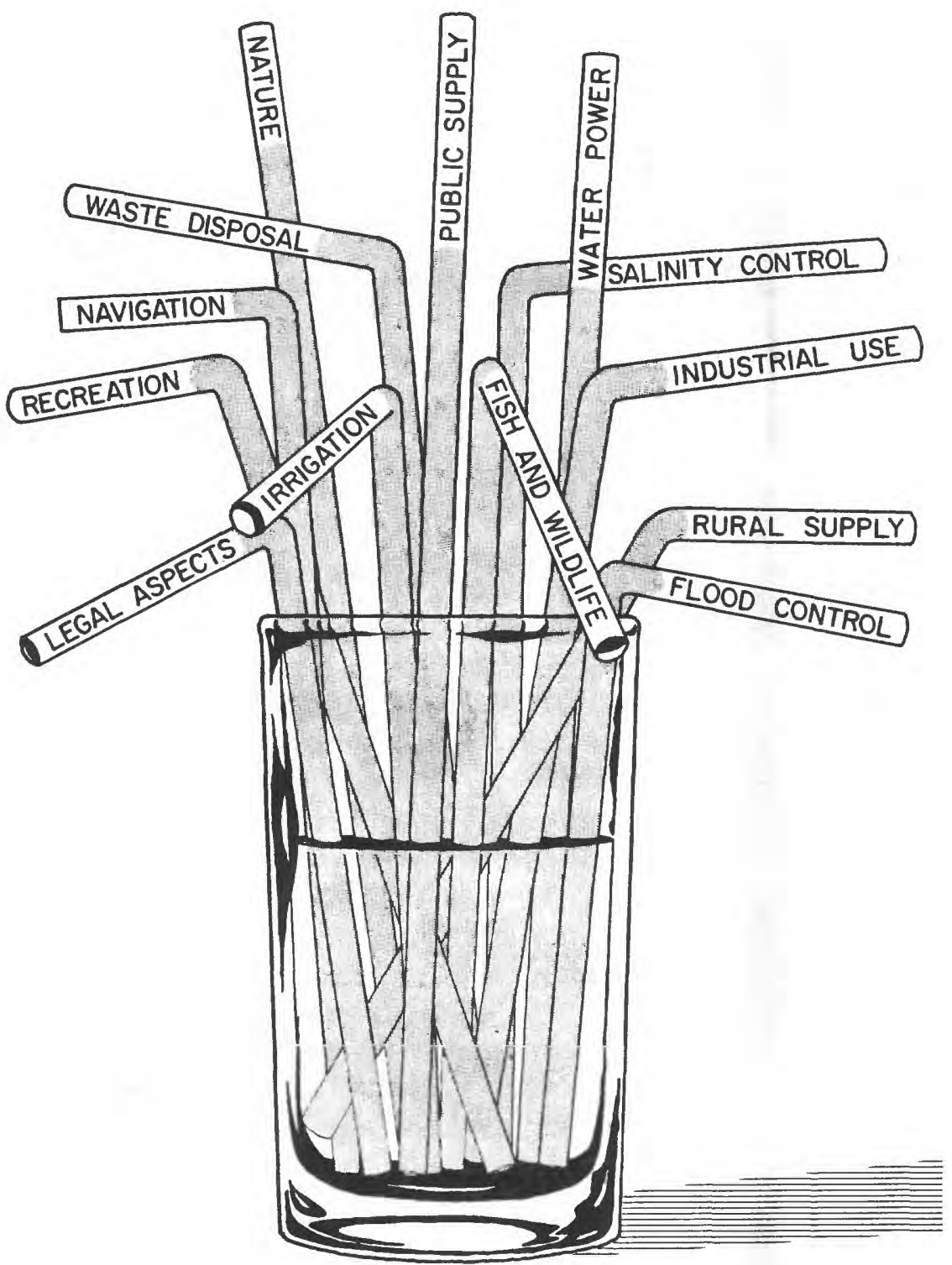

Competition for water is growing-adequate information and analysis are keys to effective development, protection, and management of a common water resource. 


\section{WATER RESOURCES ACTIVITIES IN FLORIDA 1985-86}

INTRODUCTION

This report contains summary statements of water resources activities in Florida conducted by the Water Resources Division of the U.S. Geological Survey in cooperation with Federal, State, and local agencies during 198586. These activities are part of the Federal program of appraising the Nation's water resources.

Florida is a water oriented state which for many years has experienced a mushrooming increase in population, attendant urban growth, and all the problems associated with such growth, particularly problems of protecting and preserving environmental quality. As the Florida environment is largely water sensitive, most environmental problems are water related. The Florida District of the U. S. Geological Survey has the principal responsibility at the Federal level for appraising water resources and for providing basic hydrologic data on both surface and ground water in the state.

Water resources appraisals in Florida are highly diversified, ranging from hydrologic records networks to interpretive appraisals of water resources and applied research to develop investigative techniques. Thus, water resource investigations range from basic descriptive wateravailability studies for areas of low-intensity water development and management to sophisticated cause and effect studies in areas of highintensity water development and management. The interpretive reports and records that are products of the investigations are a principal hydrologic foundation upon which the plans for development, management, and protection of Florida's water resources may be based.

The need for water resources information is especially great in urbanized areas, where concern is being expressed that the "carrying" capacity of the land and water resources is being exceeded. Increasingly intensive and sophisticated water-management programs will have to be implemented in these urban areas to meet the increasing needs for water and to maintain good water quality. Water data and information required to implement sound water-management programs in highly urbanized areas relate to the quantity and quality of storm runoff, sources of aquifer contamination, injection of wastes into deep strata, underground storage of freshwater, artificial recharge of aquifers, environmental effects of reuse of water, and effects of land development on changes in infiltrative capacity. In some areas of the State, broad areas are largely rural. Future growth is anticipated in such areas. However, recognition is given to the need for planned development tailored to the environment. The need for water information in these rural areas is related to a large extent to the need to provide for primary water development and provide information on effects of development. 
This report is intended primarily as a method of informing those agencies vitally interested in the water resources of Florida as to the current status and objectives of the U.S. Geological Survey cooperative program. The mission of this program is to collect, interpret and publish information on water resources. Almost all of this work is done in cooperation with other public agencies.
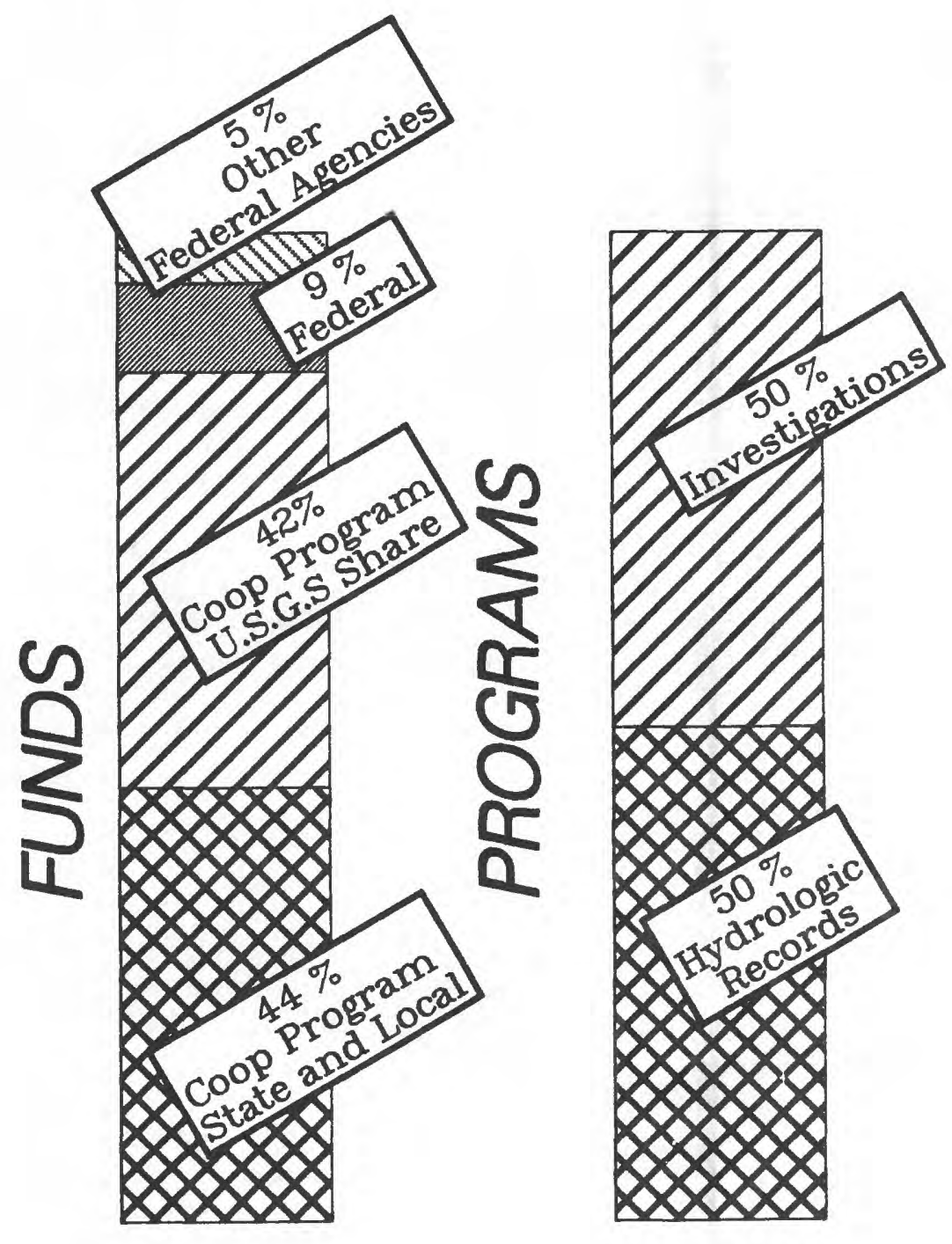

Source of funds and makeup of program, Florida District 1985-86 


\section{U.S. GEOLOGICAL SURVEY WATER RESOURCES DIVISION PROGRAMS}

Program development in the Water Resources Division is an evolving activity. Programs are reviewed regularly and future needs for water-data and hydrologic investigations are projected. Water problems and data needs brought out by State and local agencies and the public make up a major part of the planning process; thus, program development is a grassroots effort which is strongly influenced by changes in data needs and water problems.

Water Resources Division programs are of three major types: (a) data collection and dissemination, (b) problem-oriented water-resources appraisals, and (c) research. The programs are strongly interrelated; for example, theories arising from research are the foundation of data collection and problem-oriented water-resources appraisals, and data collection is a major component of all water-resources appraisals and most of the research studies.

The Division's activities may be described under three headings: Iongterm programs, topical programs, and technical-assistance programs.

Long-term programs include the Federal-State cooperative program; coordination of Federal water-data acquisition; assistance to other Federal agencies; the National Research Program; the National Water-Data Exchange; the Water Resources Scientific Information Center; the National Water-Use Information Program; the hydrologic data-collection program, including the national stream quality accounting network and the national benchmark program; and the international hydrology program. These programs are fundamental to the Division's mission and they provide the data and research needed for the topical programs.

Topical programs are designed to provide critically needed information on issues of major and immediate concern to the Nation. These programs include hazardous waste hydrology, including high- and low-level nuclear and toxic-chemical wastes; coal and oil-shale hydrology; regional aquifer systems analysis; acid rain; volcano hazards; and water-resources conditions.

Technical-assistance programs include the instrumentation program, the national water-quality laboratories, and the national training center. These programs are internal to the Division but contribute significantly to the continuing development of hydrologic capabilities and thus to the success of the Division's mission. 


\section{NATIONAL WATER DATA EXCHANGE (NAWDEX)}

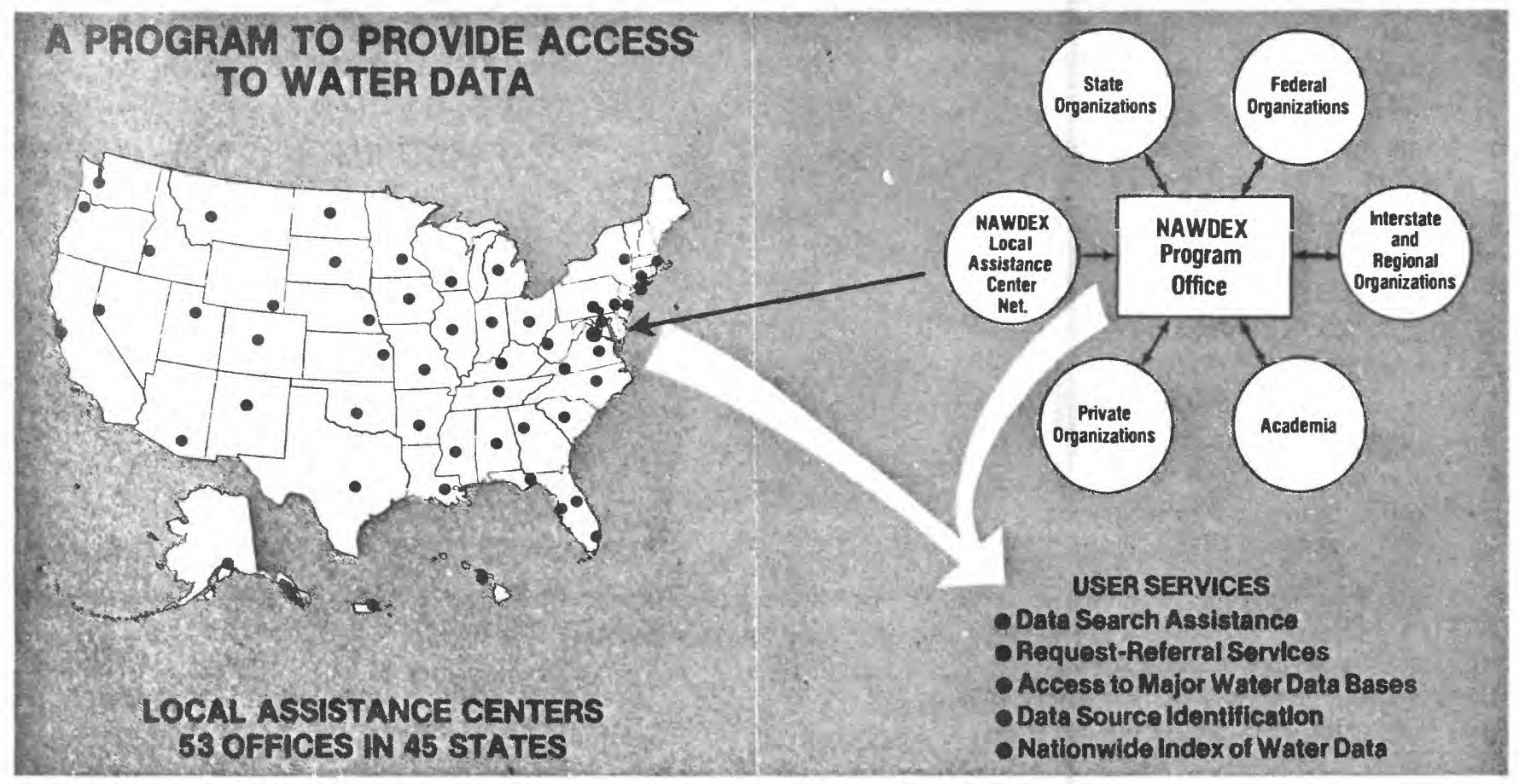

The National Water Data Exchange (NAWDEX) is a nationwide program managed by the U.S. Geological Survey to assist users of water data or water-related data in identifying, locating, and acquiring needed data. NAWDEX is a confederation of water-oriented organizations working together to make their data more readily accessible and to facilitate a more efficient exchange of water data.

A variety of user services are provided by NAWDEX. These include assistance in identifying and locating needed water data and referring the requester to the organization that retains the data required. A Water Data Sources Directory is also maintained that identifies organizations that are sources of water data and locations within these organizations from which data may be obtained. NAWDEX services are available to any organization or individual. Further information can be obtained from the NAWDEX Program Office, MS-421, National Center, Reston, VA 22092 (703) 648-6848. 


\section{NATIONAL WATER-DATA \\ STORAGE AND RETRIEVAL SYSTEM \\ (WATSTORE)}
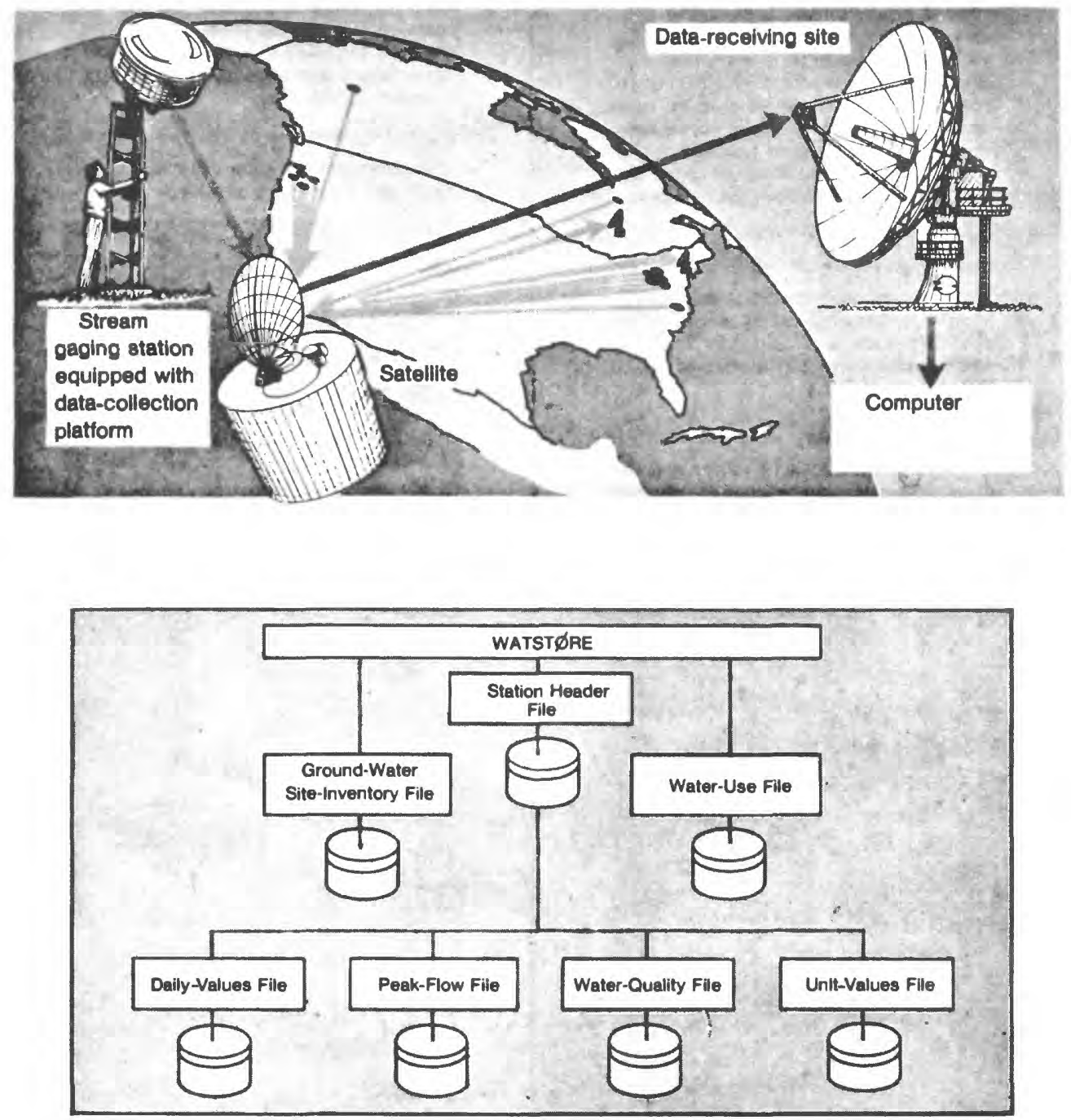

As part of the Geological Survey's program of releasing water data to the public, a large-scale computerized system has been developed for the storage and retrieval of water data collected through its activities. The National Water Data Storage and Retrieval System (WATSTORE) was established in 1971 to modernize the Geological Survey's existing water-data processing procedures and techniques and to provide for more effective and efficient management of its data-releasing activities. Data are transferred monthly from WATSTORE to the Environmental Protection Agency's storage and retrieval system (STORET). In Florida, WATSTORE data products may be obtained through the Survey's District and subdistrict offices listed on the inside front cover. A minimal fee plus the actual computer cost incurred in producing a desired product is charged to the requester. 


\section{DISTRIBUTED INFORMATION SYSTEM \\ (DIS)}

The Survey has developed a Distributed Information System (DIS) to enhance the management and availability of water resources data. The DIS is a nationwide network of 75 computers located in major Water Resource Division offices and linked by a telecommunication network. The Florida DIS consists of computers in Miami, Orlando, Tallahassee, and Tampa and a telecommunication network linking 9 Florida USGS offices with Water Management Districts and other cooperating agencies. This system has greatly improved the Survey's data base management, statistical analysis, and modeling capabilities as well as providing unprecedented access to water resources information.

To provide increased flexibility in the use of water resources information, the USGS WATSTORE Program Office is developing a data base using a hydrologic data model designed to enhance data sharing. Residing at DIS sites in Florida, the National Water Data System (NWDS) data base will integrate surface water, ground water, water quality, water use, meterologic, and operations data giving users a comprehensive view. Statistical, graphical, and simulation procedures will be available to provide additional information.

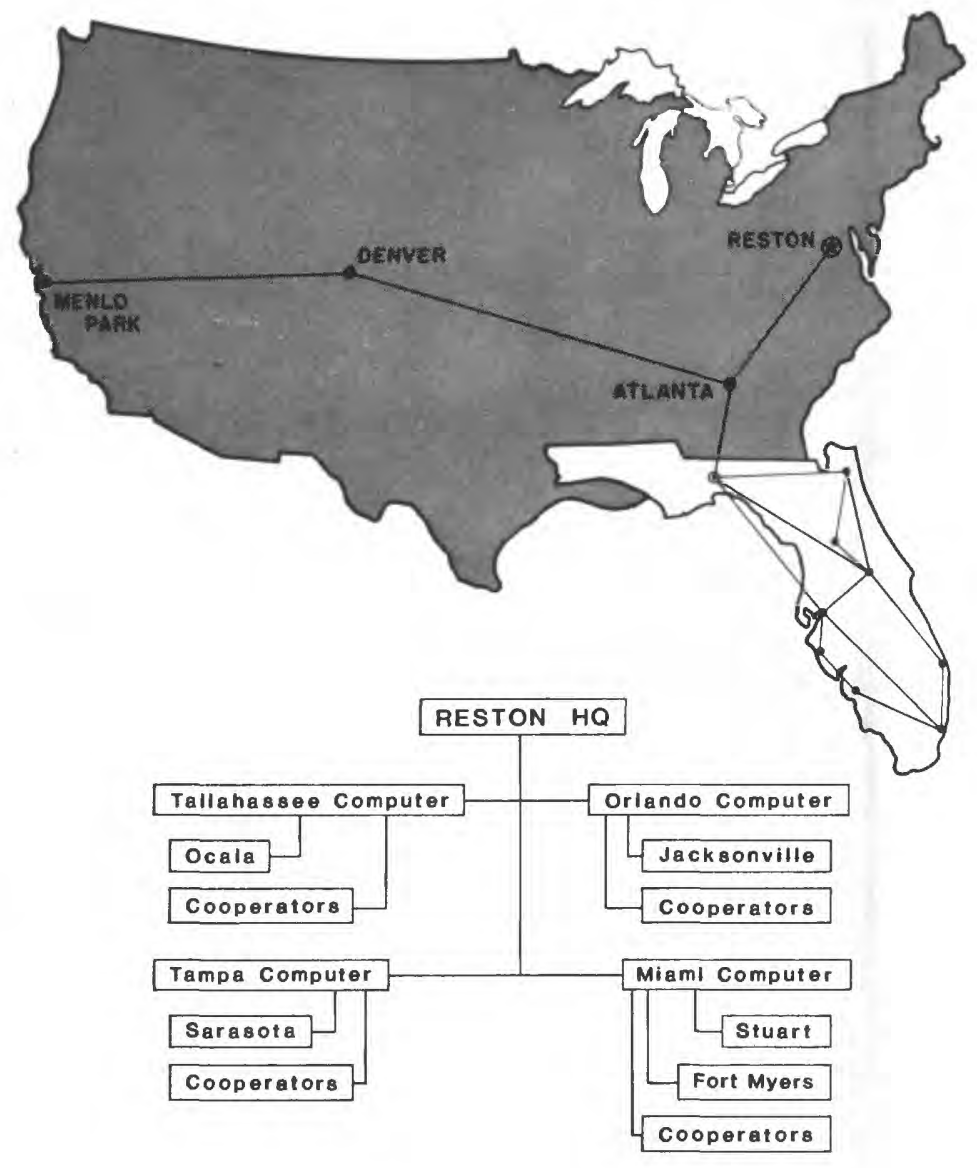




\section{THE NATIONAL STREAM QUALITY ACCOUNTING NETWORK (NASQAN)}

NASQAN is a series of stations at which systematic and continuing measure-ments are made to determine the quality of the Nation's streams. Design of the network specifies measurement of a broad range of waterquality charac-teristics selected to meet many of the information requests of groups involved in planning and management on a national or regional scale. The primary objectives are: (1) to account for the quantity and quality of water moving within and from the United States, (2) to depict areal variability, (3) to detect changes in stream quality, and (4) to lay the groundwork for future assessments of changes in stream quality.

Presently in Florida, 30 NASQAN and one hydrologic benchmark sites are strategically located in virtually all major hydrologic accounting units within the State and furnish a regionalized picture of water-quality trends in Florida's surface waters.

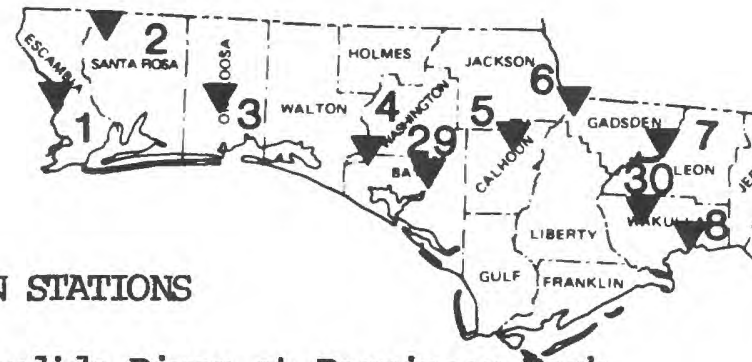

NASQAN STATIONS

1. Perdido River at Barrineau Park

2. Escambia River near Century

3. Yellow River at Milligan

4. Choctawhatchee River near Bruce

5. Chipola River near Altha

6. Apalachicola River at Chattahoochee

7. Ochlockonee River near Havana

8. St. Marks River near Newport

9. Aucilla River near Scanlon

10. Steinhatchee River near Cross City

11. Suwannee River at Branford

12. St. Marys River near Macclenny

13. St. Johns River near Deland

14. Spruce Creek near Samsula

15. Withlacoochee River near Holder

16. Hillsborough River near Zephyrhills

17. Alafia River at Lithia

18. Main Canal at Vero Beach

19. Rissimmee River at S65E near Okeechobee

20. Peace River at Arcadia

21. Myakka River near Sarasota

22. Fisheating Creek near Palmdale

23. St. Lucie Canal at Lock near Stuart

24. Caloosahatchee Canal at Otona Lock near Labelle

25. West Palm Beach Canal at West Palm Beach

26. Miami Canal at NW 36th Street, Miami

27. Tamiami Canal-40 mile bend to Monroe

O 1020304050 MILES

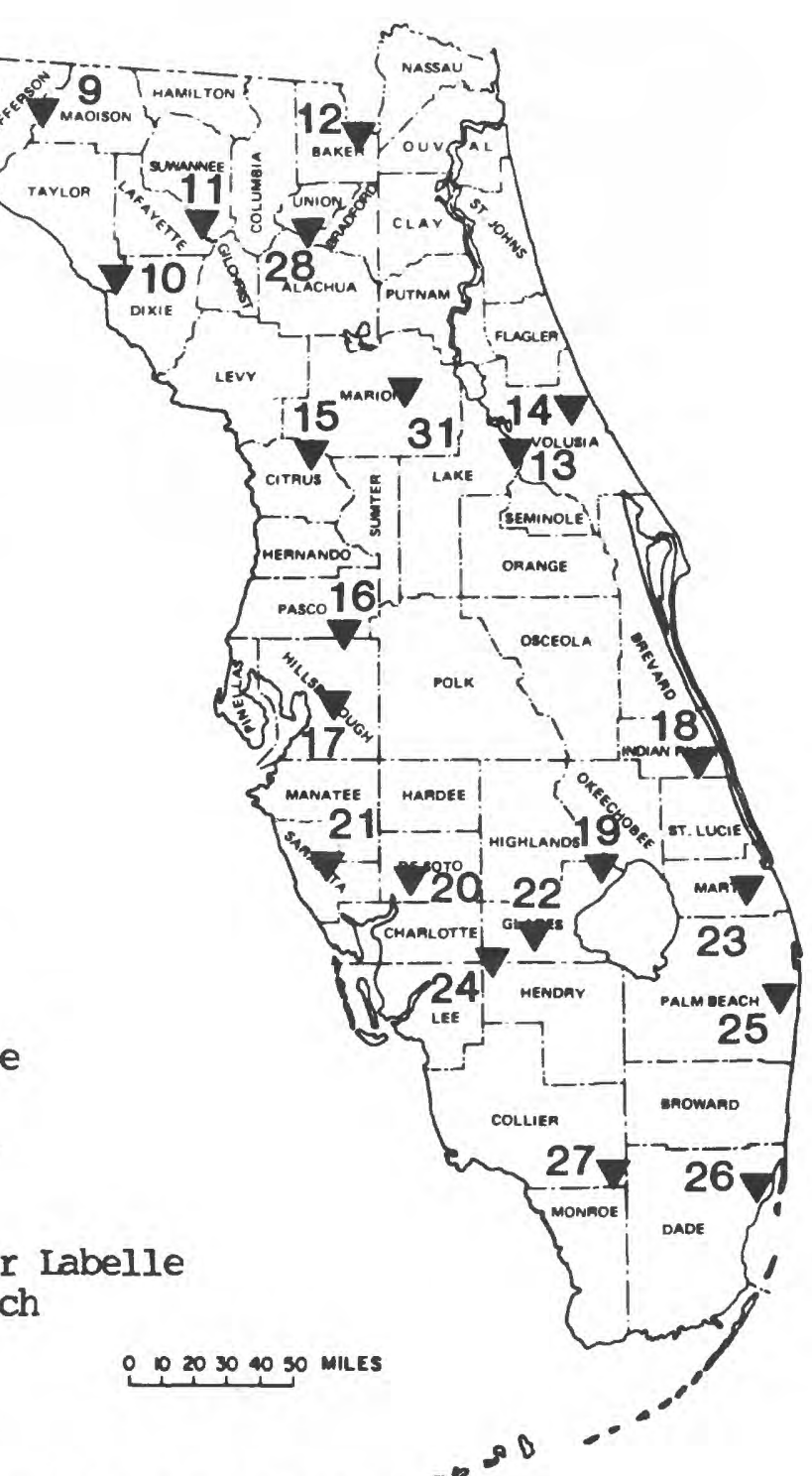

28. Econta Fe River at Worthingto

30. Sopchoppy River near Sopchoppy (hydrologic benchmark station)

31. Oklawaha River near Conner 


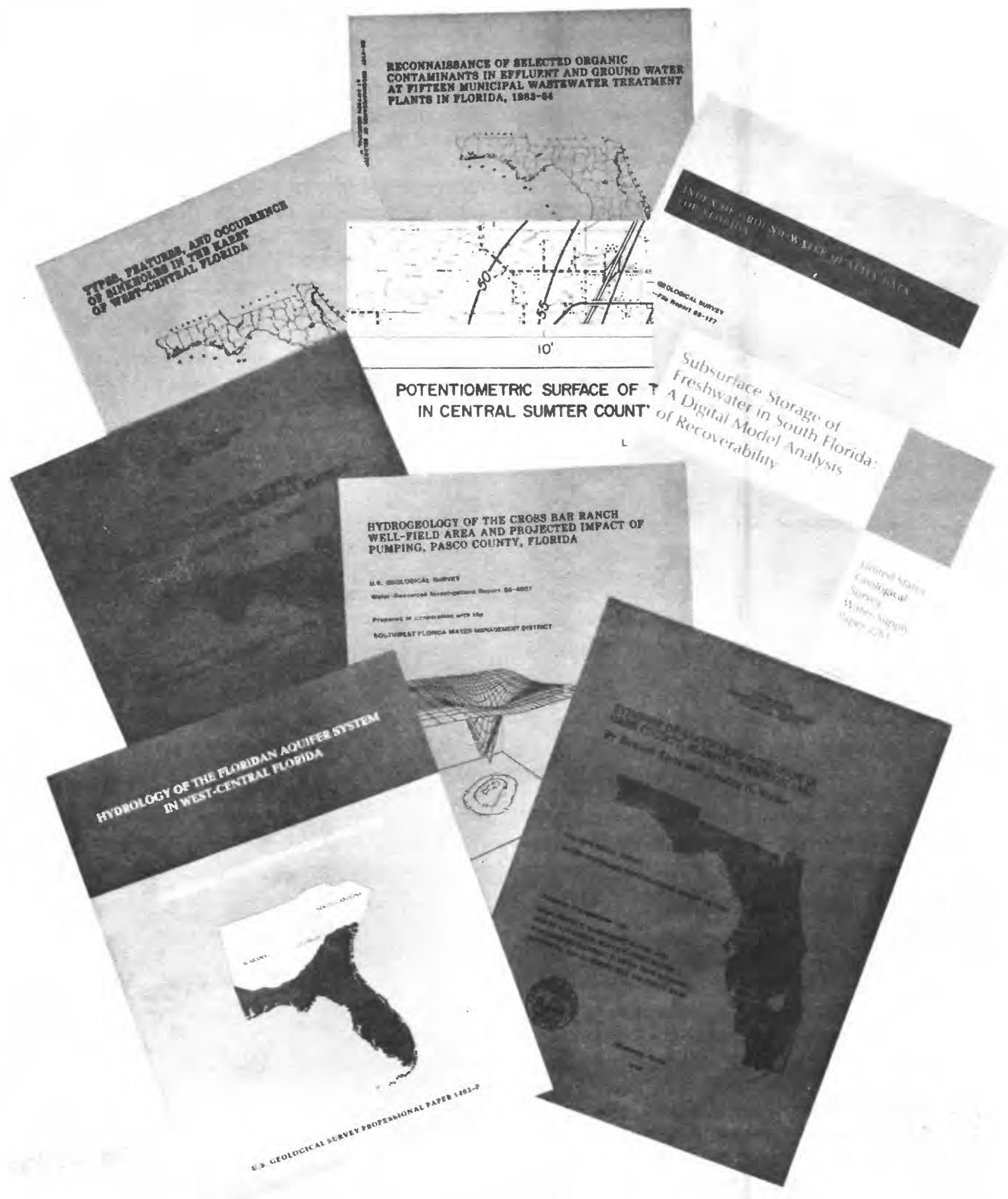

More than 50 reports were released during 1985 and more than 1,000 requests for reports were received. 


\section{NEW REPORTS FROM THE U.S. GEOLOGICAL SURVEY FLORIDA DISTRICT}

The results of many of the water resources activities of the $U$. S. Geological Survey are released in reports for use by water agencies and the public. Survey reports on the water resources of Florida are available for inspection at the offices listed on the inside of the front cover, at the offices of the five water management districts, and at libraries of the state University system. Contact the District Office for information regarding the availability of these publications.

Adams, D. B., 1985, A description of a small basin water budget study and an update of Lake Hefner evaporation methods (Abstract).

Barr, G. L., 1985, Potentiometric surface of the Upper Floridan aquifer, west-central Florida, May 1985: U.S. Geological Survey Open-File Report 85-482, 1 sheet.

1985, Potentiometric surface of the Upper Floridan aquifer, westcentral Florida, September 1985: U.S. Geological Survey Open-File Report 85-679, 1 sheet.

Bradner, L. A., 1985, Potentiometric surface of the Upper Floridan aquifer in central Sumter County, Florida, May 1985: U.S. Geological Survey OpenFile Report 85-551, I sheet.

1985, Potentiometric surface of the Upper Floridan aquifer in central Sumter County, Florida, September 1985: U.S. Geological Survey Open-File Report 85-681, 1 sheet.

1986, Hydrogeology of the Lake Miona area, northeast Sumter County, Florida: U.S. Geological Survey Water-Resources Investigations Report 85-4002, 1 sheet.

Bridges, W. C., 1985, Analysis of water-level fluctuations of the U.S. Highway 90 retention pond, Madison, Florida: U.S. Geological Survey WaterResources Investigations Report 85-4057, 19 p.

Claiborne, Maude, Wilson, T. D., and Hoy, N. D., 198, Bibliography of U.S. Geological Survey reports on the water resources of Florida, 1886-1984: U.S. Geological Survey Open-File Report 85-424 [in press].

Dresler, P. V., and Elder, J. F., 1985, Contamination, bioaccumulation, and ecological effects of creosote-derived compounds in the nearshore estuarine environment of Pensacola Bay, Florida (Abstract).

Elder, J. F., 1985, Nutrient modifications during transport through a north Florida river wetland system (Abstract).

1985, Contaminant metals in the aquatic environment: Are they removed or detoxified by natural processes? (Abstract). 
Elder, J. F., 1985, Hydrologic effects on fecal bacteria transport in the Apalachicola River, Florida (Abstract).

Elder, J. F., Flagg, S. D., and Mattraw, H. C., Jr., 198_, Hydrology and ecology of the Apalachicola River, Florida: A summary of the river quality assessment: U.S. Geological Survey Open-File Report 85-626 pending publication as Water-Supply Paper 2196-D, [in press]

Elder, J. F., Hunn, J. D., and Calhoun, C. W., 1985, Wastewater application by spray irrigation on a field southeast of Tallahassee, Florida: Effects on ground-water quality and quantity, 1980-82: U.S. Geological Survey Water-Resources Investigations Report 85-4006, 41 p.

Estevez, E. D., 198, Infaunal macroinvertebrates of the Charlotte Harbor estuarine system and surrounding inshore waters, Florida: U.S. Geological Survey Water-Resources Investigations Report 85-4260 [in press].

Fitzpatrick, D. J., 198, Hydrogeologic conditions and saline-water intrusion, Cape Coral, Florida, 1978-81: U.S. Geological Survey Water-Resources Investigations Report 85-4231 [in press].

198., Tests for injecting, storing, and recovering, freshwater in a saline artesian aquifer, Lee County, Florida: U.S. Geological Survey Water-Resources Investigations Report 85-4249 [in press].

Franks, B. J., 1985, Preliminary 3-D simulation of ground-water flow at a hazardous waste site near Pensacola, Florida (Abstract).

Franks, B. J., Goerlitz, D. F., and Baedecker, M. J., 1985, Defining extent of contamination using onsite analytical methods (Conference Paper).

, 1985, Defining extent of contaminant plume using onsite analytical techniques (Abstract)

German, E. R., 1985, Quality and quantity of drainage well inflow to the Floridan aquifer system at two lake sites in the Orlando area, Florida, with a reconnaissance of trace compounds (Abstract).

Henderson, S. E., 198, Hydrology of Hunters Lake, Hernando County, Florida: U.S. Geological Survey Water-Resources Investigations Report 85-4242 [in press].

Hickey, J. J., 1985, Subsurface injection of liquid waste in Florida (Abstract).

Howie, Barbara, and Waller, B. G., 1985, Effects of agricultural practices on ground-water chemistry in an unconfined limestone aquifer, Dade County, Florida (Abstract).

Hutchinson, C. B., 1985, Hydrogeology of the Cross Bar Ranch well-field area and projected impact of pumping, Pasco County, Florida: U.S. Geological Survey Water-Resources Investigations Report 85-4001, 89 p. 
Irwin, G. A., and Pruitt, J. B., 1985, Quality assurance for a ground-water sampling reconnaissance of priority pollutants (Abstract).

Klein, Howard, and Waller, B. G., 1985, Synopsis of saltwater intrusion in Dade County, Florida, through 1984: U.S. Geological Survey WaterResources Investigations Report 85-4101, 1 sheet.

Martin, E. H., 1985, Changes in stormwater quality in detention basins, preliminary results (Abstract).

1985, Effectiveness of a detention pond and wetlands system in reducing the amounts of lead transported by urban stormwater runoff (Conference Paper).

Martin, E. H., and Smoot, J. L., 1986, Constituent-load changes in urban stormwater runoff routed through a detention pond-wetlands system in central Florida: U.S. Geological Survey Water-Resources Investigations Report 85-4310.

McPherson, B. F., 1985, An environmental assessment of the Charlotte Harbor estuarine system, Florida-an overview (Abstract).

Merritt, M. L., 1986, Recovering freshwater stored in saline limestone aquifers: Ground Water, July-August 1986 [in press].

, 1985, Subsurface storage of freshwater in south Florida: A digital model analysis of recoverability: U.S. Geological Survey Water-Supply Paper 2261, 44 p.

1985, Recovery of freshwater stored in saline limestone aquifers (Abstract).

Miller, R. A., 1985, Using bulk-precipitation data to analyze the movement of chemical constituents in urban stormwater (Conference Paper).

Miller, R. L., 1985, Some concepts and techniques for reviewing major ion analyses of natural water (Journal Article).

Miller, W. L., 1985, Altitude of water table, surficial aquifer, Palm Beach County, Florida, April 24-26, 1985: U.S. Geological Survey Open-File Report 85-336, 1 sheet.

1985, Altitude of water table, surficial aquifer, Palm Beach County, Florida, November 9-14, 1985: U.S. Geological Survey Open-File Report $85-637,1$ sheet.

Pruitt, J. B., Troutman, D. E., and Irwin, G. A., 1985, Reconnaissance of selected organic contaminants in effluent and ground water at fifteen municipal wastewater treatment plants in Florida, 1983-84: U.S. Geological Survey Water-Resources Investigations Report 85-4167, 29 p.

Ryder, P. D., 1985, Hydrology of the Floridan aquifer system in west-central Florida: U.S. Geological Survey Professional Paper 1403-F, 63 p. 
Schiner, G. R., and Hayes, E. C., 1984, Potentiometric surface of the Upper Floridan aquifer in the St. Johns River Water Management District and vicinity, Florida, September 1985: U.S. Geological Survey Open-File Report 84-865, 1 sheet.

1 1985, Potentiometric surface of the Upper Floridan aquifer in the St. Johns River Water Management District and vicinity, Florida, May 1985: U.S. Geological Survey Open-File Report 85-491, 1 sheet.

1985, Potentiometric surface of the Upper Floridan aquifer in the St. Johns River Water Management District and vicinity, Florida, September 1985: U.S. Geological Survey Open-File Report 85-644, I sheet.

Seaber, P. R., 1985, Influence of hydrogeology on ground-water contamination from phosphate industry waste-disposal operations (Abstract).

Seaber, P. R., and williams, O. O., 1985, Index of ground-water quality data for Florida: U.S. Geological Survey Open-File Report 85-177, 478 p.

Sinclair, W. C., Stewart, J. W., Knutilla, R. I., Gilboy, A. E., and Miller, R. L., 1985, Types, features, and occurrence of sinkholes in the karst of west-central Florida: U.S. Geological survey Water-Resources Investigations Report 85-4126.

Stoker, Y. E., 1986, Water quality of the Charlotte Harbor estuarine system, Florida, November 1982 through October 1984: U.S. Geological Survey Open-File Report 85-563, 213 p.

Tibbals, C. H., 198, Hydrology of the Floridan aquifer system in eastcentral Florida: U.S. Geological Survey Professional Paper 1403-F [in press].

Trapp, Henry, Jr., and Geiger, L. H., 198_, Three-dimensional steady-state simulation of flow in the sand-and-gravel aquifer, southern Escambia County, Florida: U.S. Geological Survey Water-Resources Investigations Report 85-4278 [in press].

Vecchioli, John, 1985, Injection of Iiquid wastes into Florida's carbonate aquifers (Abstract).

Waller, B. G., 1985, Drought of 1980-82 in southeast Florida with comparison to the 1961-62 and 1970-71 droughts: U.S. Geological Survey WaterResources Investigations Report 85-4152, 29 p.

1985, Flood reduction efficiency of the water-management system in Dade County (Miami) Florida, after Hurricane Donna (1960) and Tropical Storm Dennis (1981) (Abstract).

Waller, B. G., and Howie, Barbara, 1985, Procedures for sampling an unconfined aquifer for contamination by agricultural chemicals, Dade County, Florida (Abstract).

Waller, B. G., and Klein, Howard, 1985, Saltwater intrusion in a highly transmissive unconfined aquifer, after 40 years of water management in Miami, Florida (Abstract). 
How to Obtain Reports Prepared by the Florida District

The Florida District has been preparing reports on water resources for several decades. Beginning in 1974, titles of Open-File Reports and Water-Resources Investigations Reports, two series frequently used for reports prepared by the Florida District, were added to the catalog "Publications of the Geological Survey." Most titles of reports prepared in Florida water resources are included in that catalog. For information on availability of reports, please write to the District Chief, U.S. Geological Survey, Suite 3015, 227 North Bronough Street, Tallahassee, Florida 32301.

New reports are announced monthly in "New Publications of the Geological Survey," subscriptions to which are available free upon request to the U.S. Geological Survey, 582 National Center, Reston, VA 22092

\section{PUBLICATION SERIES}

Open-File Reports (Florida)

Water-Resources Investigations (Florida)
CONIACT

Florida District Office 227 N. Bronough Street Suite 3015

Tallahassee, FL 32301

Florida Bureau of Geology 903 W. Tennessee Street Tallahassee, FL 32304
Florida Bureau of Geology Bulletins Map Series

Reports of Investigations Information Circulars

U.S. Geological Survey Books: Bulletins Circulars Professional Papers Water-Supply Papers

U.S. Geological Survey Maps: Hydrologic Investigations Atlases Hydrologic Unit Maps
Eastern Distribution Branch U.S. Geological Survey 604 S. Pickett Street Alexandria, VA 22304

Eastern Distribution Branch U.S. Geological Survey 1200 South Eads Street Arlington, VA 22202 


\section{FLORIDA WATER RESOURCES RESEARCH CENTER}

The Florida Water Resources Research Center, funded by the Department of the Interior, was established in 1964 as a result of the passage of Public Law 88-379-The Water Resources Research Act of 1964-"to stimulate, sponsor, provide for, and supplement present programs for conduct of research, investigation, experiments, and the training of scientists in the fields of water and of resources which affect water." Late in 1983, management of this program was transferred to the U.S. Geological survey.

Under the administration of the Center, current water resources pertaining to the achievement of adequate statewide water resource management, and water quality and quantity are being conducted by faculty at the University of Florida and at other universities in the state. For further information concerning the Center, contact Dr. James P. Heaney, Director, Florida Water Resources Research Center, 424 A.P. Black Hall, University of Florida, Gainesville, FL 32611 (904) 392-0840. A list of new publications resulting from the center projects is presented below:

No. 83 A STORMWATER COLLECTION AND RESUSE SYSTEM FOR THE KENNEDY SPACE CENITER, FLORIDA, by D. S. DWOrnik, 1984.

No. 84 EFFECIS OF PRECIPITATION ON WATER USE IN GAINESVILLE, FLORIDA, bY B. J. Walker, 1982 .

No. 85 DISCRETE-TIME POINT PROCESS MODELS FOR DAILY RAINFALL, by E. Foufoula, 1985 .

NO. 86 CONTINUOUS SIMULATION OF SURFACE AND SUBSURFACE FLOWS IN CYPRESS CREEK BASIN, FLORIDA, USING HYDROLOGICAL SIMULATION PROGRAMFORTRAN (HSPF), by C. N. Hicks, 1985.

NO. 87 EFFECTS OF HARVESTING CYPRESS SWAMPS ON WATER QUALITY AND QUANTITY, by K. C. Ewel, 1985.

NO. 88 THE GEOPHYSICAL AND GEOLOGIC CHARACTERISTICS OF FRACIURE ZONES IN THE CARBONATE FLORIDAN AQUIFER, by M. T. Stewart, 1985.

NO. 89 IMPACIS OF DEVEIOPNENT ON THE WATER RESOURCES OF CYPRESS CREER, NORTH OF TAMPA, by J. P. Heaney, W. C. Huber, W. C. Downs, M. C. Hancock, and C. N. Hicks, 1986. 


\section{MAPS OF FLOOD-PRONE AREAS}

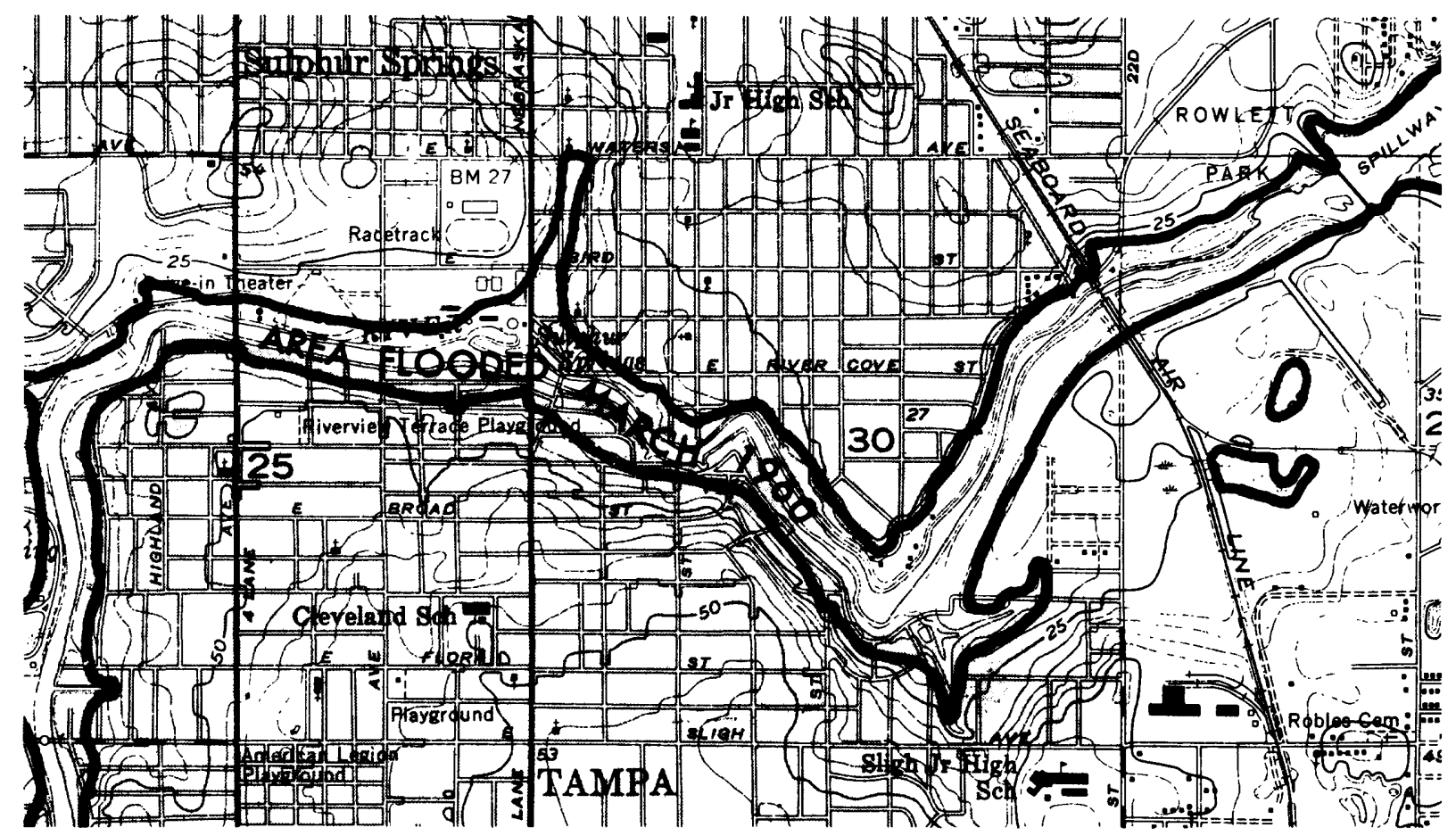

Floods in the United States cause an average yearly loss of about 80 lives and $\$ 1$ billion. Improvements in flood forecasting and rapid commications have decreased the number of lives lost in recent years, but the dollar loss and the tragedy of damaged or lost homes are increasing.

The flow of a river is usually confined to a well-defined channel that meanders through the river valley. However, at times the river overflows because of heavy rains and uses the wide, flat areas adjacent to the channel to carry a part of the flow. During a major flood, this flood plain may be covered to a depth of many feet with water moving at a high velocity.

The flood plain may appear to be an attractive area for development, particularly in urban communities where land is expensive. Many housing projects and commercial and industrial buildings have been constructed on the flood plains because people tend either to forget past experiences or to be unaware of possible flood danger.

A national program for managing flood losses was started by the Federal Government in 1966. As a part of this program, the U.S. Geological Survey outlined flood-prone areas on topographic maps to indicate localities that may be subject to flood losses. For Florida, these maps can be obtained through the Florida Resources and Environmental Analysis Center, Room 361, Bellamy Building, Florida State University, Tallahassee, FL 32306, Telephone: (904) 644-2883. Flood-prone areas for most counties and cities in Florida have been defined by detailed studies or by approximate methods and maps of these areas are available (free) through: Federal Emergency Management Agency, Flood Map Distribution Center, 6930 (A-F) San Tomas Road, Baltimore, MD 21227-6227, Telephone: (800) 638-6620 (toll free). 


\section{LOCATION OF AREAL INVESTIGATIONS AND THE FIVE WATER MANAGEMENT DISTRICTS}

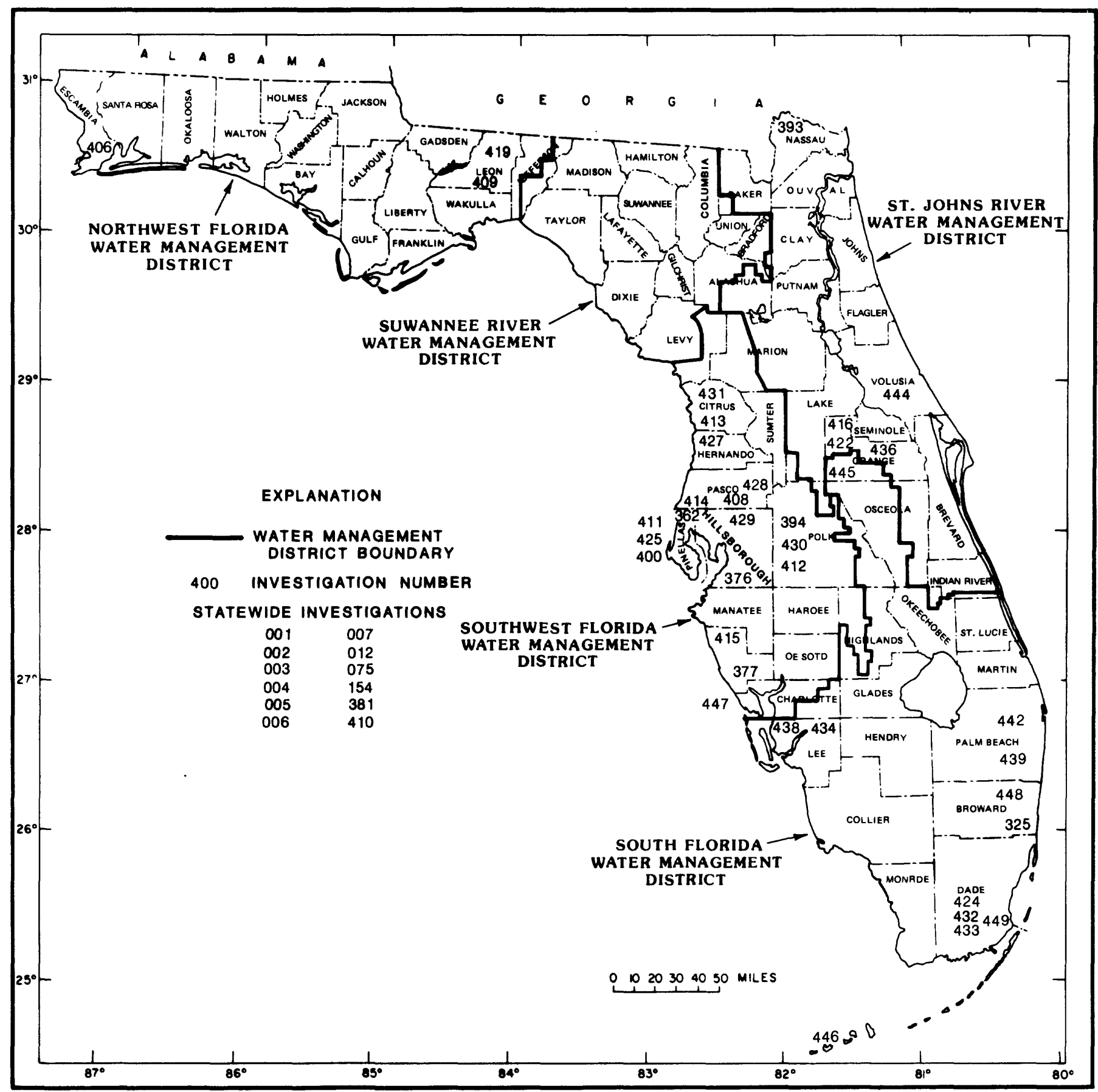


1985-86

Number

Title

Page

001

002

003

005

006

007

012

075

154

325

362

376

377

Surface water network stations 20

Ground water network stations

Quality of water network stations

Quality of precipitation

Less detailed flood insurance studies

Annual water-use inventory

Flood assessment

Florida water atlas

Subsurface waste storage, Florida

Appraisal of the surficial aquifers of the lower east coast of Florida

Evaluation of stormwater detention basins in westcentral Florida

Effects of urban development on the hydrology of coastal areas of Florida

Environmental assessment study of the Charlotte Harbor estuarine system and surrounding area, southwest Florida

Reaeration capacity of streams and estuaries in Florida

Flow characteristics of Nassau River basin and estuary

Wetland ecosystem reclamation after phosphate mining, west-central Florida

Saltwater-intrusion models for selected areas, westcentral Florida

occurrence, fate and movement of organic contaminants in ground water near Pensacola, Florida (vicinity of American Creosote, Inc.)

Hydrology and water quality of Pasco County, Florida

410 Adaptation of Floridan aquifer system RASA models for water-management needs, Florida

411 Hydrologic evaluation of the potential water supply of the intermediate aquifer system, southwest Florida

412 Simulation approaches to understanding ground-water surface-water relationships anả water budgets in Florida lakes

413 Impact of reduced freshwater inflow on the salinity characteristics of the Withlacoochee River estuary and the coastal rivers estuarine zone of Citrus and Hernando Counties, Florida

414 Impact of altered freshwater flow on the salinity characteristics of the Anclote River estuary, Florida

415 Assessment of hydrogeologic conditions and alternatives for safeguarding water quality in southwest Sarasota county, Florida 
416 Effects of highway runoff on the water quality of wetlands and ground water

419 Mobility and stability of organic compounds in treated wastewater applied by spray irrigation to fields near Tallahassee, Florida

422 Impacts of selected developmental activities on the quality of water in the Floridan aquifer system, central Florida

424 Quantity and quality of water applied to irrigated crops of selected sites in the East Glades Agriculture area, South Dade County, Florida

425 Reconnaissance of water quality at a Department of Energy site, Pinellas County, Florida

427 Pollution potential of the Floridan aquifer system from sinkholes and internally drained areas in westcentral Florida

428

Surface-water ground-water relationships in northwest Hillsborough, northwest Pinellas, and south Pasco Counties

Hydrology of Citrus Park area, Hillsborough County, Florida

430

Geologic controls on ground-water movement and contamination in Polk county, Florida

431 Surface water hydrology of the Floral City Pool of Tsala Apopka Lake, west-central Florida

432 Effects on ground-water quality from the application of domestic wastewater-treatment sludge to soils overlying the Biscayne aquifer, Dade County, Florida

Effects of stormwater contaminants from exfiltration trenches on the Biscayne aquifer, Dade County, Florida

434 Effects of well plugging in ground-water quality in the Fort Myers, Florida, area

436 Quality of ground water in the Floridan aquifer system as related to selected land use, central Florida

438 Tide-induced circulation and flushing using tide gates in residential canals at Cape Coral, Florida

439 Numerical simulation of the migration of landfill leachate in a highly permeable surficial aquifer, Palm Beach County, Florida

442 Effects of septic tanks and domestic wells on water quality and levels, northeast Palm Beach County, Florida

444 Geohydrology of the surficial aquifer system, Volusia County, Florida 
445 Assessment of water-quality processes affecting

446 Wuter resource evaluation of the freshwater lens on Key West, Florida - 92

447 Salinity characteristics and effects of freshwater withdrawals, Myakka River, Florida

448 Procedures for assessing water use from the sole source Biscayne aquifer, southeast Florida, using a GIS (Geographic Information System)

449 Simulation of a saltwater plume from a flowing well in a surficial aquifer, Dade County, Florida 
DATE PRQJECT BEGAN: 1926

DATE PROJECT ENDS: Continuing

PROJECT COORDINATOR: W. C. Bridges, Tallahassee

PRINCIPAL AREA INVESTIGATORS: L. D. Fayard, Orlando; W. J. Haire, Miami;

R. T. Mycyk, Tampa; M. A. Franklin, Talla.

COOPERATING AGENCIES: Most of the agencies shown in the list of cooperators.

PROBLEM: Surface-water information is needed for purposes of surveillance, planning, design, hazard warning, operation, and management in water-related fields such as water supply, flood control, irrigation, bridge and culvert design, wildlife management, pollution abatement, flood-plain management, and water resources development. To provide this information, an appropriate data base is necessary.

OBJECTIVE: To obtain and document an unbiased inventory of streamflow, stream and lake stage data for use in the planning and development of the water resources of the State of Florida.

APPROACH: Collect stream discharge, stream and lake stage data from a network of gaging stations that include daily discharge, periodic discharge, daily stage, and periodic stage stations to define streamflow and stage conditions within the State of Florida.

PROGRESS \& SIGNIFICANI RESUIIS: Streamflow and stage data were collected from 650 network sites and prepared for publication. Streamflow and stage data currently are being obtained at the number of hydrologic data network stations given below.

Station Classification

Stream stations

Continuous record:

Discharge and Stage......... 264

Stage Only............... 72

Partial record:

Peak (maximum) flow.......... 82

Periodic Streamflow......... 30

Lake and reservoir stations...........
Stage and contents............. 4

Stage only

Continuous............... 57

Periodic................. 82

\section{Number of Stations}

\section{8}


(FL-001)

PLANS FOR THIS YEAR: Continue operations as needs are defined.

REPORTS IN PROCESS:

Water-resources data for Florida, water year 1984 and 1985.

REPORTS RETEASED:

U.S. Geological Survey, 1984, Water resources data for Florida-1983, northeast Florida: U.S. Geological Survey Water-Data Report FL-83-1A.

U.S. Geological Survey, 1984, Water resources data for Florida-1983, south Florida Surface Water: U.S. Geological Survey Water-Data Report FL-83-2A.

U.S. Geological Survey, 1984, Water resources data for Florida-1983, southwest Florida Surface Water: U.S. Geological Survey Water-Data Report FL-83-3A.

U.S. Geological Survey, 1984, Water resources data for Florida-1983, northwest Florida: U.S. Geological Survey Water-Data Report FL-83-4. 
FL-002 GROUND WATER NETWORR STATIONS

DATE PROJECT BEGAN: 1930

DATE PROJECT ENDS: Continuing

PROJECT COORDINATOR: W. C. Bridges, Tallahassee

PRINCIPAL AREA INNESTIGATORS: L. D. Fayard, Orlando; W. J. Haire, Miami;

R. T. Mycyk, Tampa; M. A. Franklin, Talla.

COOPERAIING AGENCIES: Most of the agencies shown in the list of cooperators

PROBLEM: Long term water level records are needed to evaluate the effects of climatic variations on the recharge to and discharge from the groundwater systems, to provide a data base from which to measure the effects of development, to assist in the prediction of future supplies, and to provide data for management of the resource.

OBJECIIVE: To obtain and document an unbiased inventory of water-level data for use in the planning and development of the water resources of the state of Florida.

APPROACH: Collect water-level data for the various aquifers by a network of observation wells which includes 1511 periodic observations sites and 478 sites where data are recorded continuously.

PROGRESS \& SIGNIEICANT_RESULTS: Water-level data were collected and published as planned.

PLANS FOR IHIS YEAR: Collection and publication of data will be continued.

RAPORTS IN PROCFSS:

Water-resources data for Florida, water year 1984 and 1985.

REPORTS RET.EASED:

U.S. Geological Survey, 1984, Water resources data for Florida-1983, northeast Florida: U.S. Geological Survey Water-Data Report FL-83-1B.

U.S. Geological Survey, 1984, Water resources data for Florida-1983, south Florida Surface Water: U.S. Geological Survey Water-Data Report FL-83-2B.

U.S. Geological Survey, 1984, Water resources data for Florida-1983, southwest Florida Surface Water: U.S. Geological Survey Water-Data Report FL-83-3B.

U.S. Geological Survey, 1984, Water resources data for Florida-1983, northwest Florida: U.S. Geological Survey Water-Data Report FL-83-4. 
DATE PROJECT BEGAN: 1939

DATE PROJECT ENDS: Continuing

PROJECT COORDINATOR: W. C. Bridges, Tallahassee

RRINCIPAL AREA INVESTIGATORS: L. D. Fayard, Orlando; W. J. Haire, Miami;

R. T. Mycyk, Tampa; M. A. Franklin, Talla.

COOPERAIING AGENCIES: Most of the agencies shown in the list of cooperators

PROBLEM: Water resource planning and water-quality assessment require a nationwide base level of relatively standardized information. For intelligent planning and realistic assessment of the water resource, the chemical and physical quality of surface and ground waters must be defined and monitored.

OBJECTIVE: To obtain and document unbiased inventory of water-quality data for use in the planning and development of the water resources of the State of Florida.

APRRACH: Collect water-quality data from a network of daily, weekly, and periodic stations which include streams, lakes, springs, and wells to define water quality conditions within the State of Florida.

PROGRESS \& SIGNIFICANT_RESULTS: Water-quality data are obtained at 318 surface-water network stations. These stations are used to monitor the quality of surface water in Florida. Some of these stations also are part of a U.S. Geological Survey nationwide network known as the National Stream Quality Accounting Network which is used to detect nationwide trends in water quality. The types of data determined at these sites are given below. Inasmuch as several types of data may be determined at a particular site and not all types of data are determined at each site, the number given below will not equal the total number of surface water sites.

\section{Data Classification}

Physical data:

Temperature, specific conductance

or ph.......................

Sediment..........................

Chemical data:

Inorganic constituents..............

Organic constituents...............

Pesticides..................

Radiochemical data...................

Biological data...................

\section{7}

31

97

59

16

6

45 
Water-quality data are obtained at network observation wells and springs. The types of data determined at these sites are listed below. Inasmuch as several types of data may be determined at a particular site, and not all types of data are determined at each site, the number given below will not equal the total number of ground water sites.

Data Classification

Physical data:
Wells

587

5

Chemical data:

Inorganic constituents.

Organic constituents

Biological

data.
136

3

67
Springs

REPORIS IN PROCESS:

Water-resources data for Florida, water year 1984 and 1985.

REPORIS RELEASED:

U.S. Geological Survey, 1984, Water resources data for Florida-1983, northeast Florida: U.S. Geological Survey Water-Data Report FL-83-1A.

U.S. Geological Survey, 1984, Water resources data for Florida-1983, northeast Florida: U.S. Geological Survey Water-Data Report FL-83-1B.

U.S. Geological Survey, 1984, Water resources data for Florida-1983, south Florida Surface Water: U.S. Geological Survey Water-Data Report FL-83-2A.

U.S. Geological Survey, 1984, Water resources data for Florida-1983, south Florida Ground Water: U.S. Geological Survey Water-Data Report FL-83-2B.

U.S. Geological Survey, 1984, water resources data for Florida-1983, southwest Florida Surface Water: U.S. Geological Survey Water-Data Report FL-83-3A.

U.S. Geological Survey, 1984, Water resources data for Florida-1983, southwest Florida Ground Water: U.S. Geological Survey Water-Data Report FL-83-3B.

U.S. Geological Survey, 1984, Water resources data for Florida-1983, northwest Florida: U.S. Geological Survey Water-Data Report FL-83-4. 
DATE PROJECT BEGAN: July 1983

DATE PROJECT ENDS: Continuing

PRINCIPAL INVESTIGATIORS: D. Briane Adams, Tampa

George A. Irwin, Tallahassee

COOPERATING AGENCY: Federal Program

PROBLEM: The amount of substances dispersed in the atmosphere and deposited by precipitation, aerosols, and bases is expected to continue to increase throughout North America. Thus, there is a need for careful measurement of the amounts, nature, and effects of these substances. Such measurements are essential for responsible management of the agricultural, forest, and aquatic ecosystems of the United States.

OBJECIIVE: The National Atmospheric Deposition Program (NADP) was created to conduct research on atmospheric deposition and its affect on surface waters and agricultural and forest lands in cooperation with federal, state and private research agencies. The U.S. Geological Survey (USGS) is participating in this program under the title of the National Trends Network (NIN) by establishing up to 40 stations nationwide with coordination and analytical services provided by NADP. These stations are established for the purpose of long term coordinated data collection for use in local, regional and national studies.

APPROACH: Basic data atmospheric deposition will be collected at a NADP/NTN approved site (N39). Methods of data collection and instrumentation conform to NADP procedures and guidelines. Data collection will be continuous with weekly sample collections in addition to collecting additional samples for non-standard events. All samples will be shipped to NADP Central Analytical Laboratory (CAL) which is operated by the Illinois State Water Survey.

PROGRESS \& SIGNIFICANT RESUIIS: Data collection continued throughout the year at the Verna and Quincy sites.

PLANS FOR THIS YEAR: The data collection sites will be maintained and operated according to National Atmospheric Deposition Program/National Trends Network (NADP/NIN) standards and schedule.

REPORTS IN PROCESS: No reports planned for this project; data will be stored in WAISTORE data files. 
FL-006 LESS DETAILED FLOOD INSURANCE STUDIES

DATE PROJECT BEGAN: April 1985

DATE PROJECT ENDS: June 1986

PRINCIPAL INVESTIGATOR: Wayne C. Bridges, Tallahassee

COOPERATING AGENCY: Federal Emergency Management Agency

PROBLEM: The National Flood Insurance Act of 1968 and the Flood Disaster Protection Act of 1973 provides for the operation of a flood insurance program. The Federal Emergency Management Agency (FEMA) needs flood studies in selected areas to determine applicable flood insurance premium rates.

OBJECIIVE: To conduct the necessary hydrologic and hydraulic evaluations and studies of areas assigned by FEMA and to present the results in an appropriate format.

APPROACH: To conduct the necessary evaluations or to conduct surveys by ground or photogrammetric methods. Determine flood-discharge frequency relationships using local historical information, gaging station records, or other applicable information. Determine water-surface profiles using step-backwater models or by other acceptable methods and furnish the results in reports prepared to FEMA specifications.

PROGRESS\&_SIGNIEICANT RESULIS: Eleven communities were selected for study. The study for Calhoun County was completed and the report submitted to FEMA.

PLANS FOR THIS YEAR: Field data will be analyzed, and reports completed and submitted to FEMA for the remaining 10 communities-Chattahoochee, Graceville, Caryville, Mount Dora, Umatilla, Tavares, Waldo, Lake City, Lake Wales, and Baker County. 
FL-007 ANNUAL WATERR-USE INNENTORY

DATE PROJECT BEGAN: JUly 1975

DATE PROJECT ENDS: Continuing

PRINCIPAL INVESTIGATOR: R. Rumenik, District Office, Tallahassee

COOPERATING AGENCIES: Florida Department of Environmental Regulation, Northwest Florida Water Management District, St. Johns River Water Management District, South Florida Water Management District, Southwest Florida Water Management District and Suwannee River Water Management District.

PROBLEY: Florida is undergoing a rapid growth in population and industry. With this growth the competition for water for municipal, rural, industrial, agricultural, and thermoelectric power has become more acute. Although water-use data have been collected every 5 years since 1965 in the State, there is a need to collect the data annually.

OBJECIIVE: The objective of this joint state and Federal effort is to provide a reliable estimate of the annual water use by county, by Water Management Districts (WMDs), and by hydrologic units. This annual evaluation will aid the WMDs in determining water-use trends and in developing water-use plans and issuing water use permits. Water-use data will be updated annually and published every 5 years starting in 1980 . In addition, much effort will be expended to research methods of improving techniques for data collection and to standardize the storage and retrieval of water-use information. The collection of site-specific data for use in hydrologic studies will also be intensified.

APPBOACH: Collect and compile water-use information annually through the concerted efforts of the U.S. Geological Survey and the State's Water Management Districts from the following sources: public-supply water systems, rural self-supplied domestic and livestock systems, industrial self-supplied systems, irrigation self-supplied systems, and thermoelectric self-supplied systems. Upgrade the quality of data by minimizing estimated values where actual values are attainable by enhancing methods and procedures for collecting data, and by maintaining all data in an automatic data system. St. Johns River Water Management District serves as the lead agency responsible for the coordination of water-use activities within the State; prior to 1985, USGS served in this capacity.

PROGRESS \& SIGNIFICANT_RESUITS: A water-use coordinating committee represented by water management districts and the U.S. Geological Survey was formed to address the continuing need for cooperation and coordination in the water use State program and to develop uniform methods for collection and computer storage of water-use data. Under a cooperative agreement, St. Johns River Water Management District is the responsible agency for five water management districts within the state. Development of techniques for improving the accuracy of irrigation water-use data collected in 16 counties in the SWFWM area were continued. 
RIANS FOR THIS YEAR: Coordinate efforts between USGS and the five water management districts for collecting and entering in a computer system all categories of water-use data by water management district boundaries, by counties, and by hydrologic units. Prepare a State report of estimates of water used in 1985; and furnish data for a national water-use report. Continue monitoring the benchmark farms and collect and compile 1985 irrigation water-use data for counties in southwest Florida.

REPORIS IN PROCESS:

Geiger, L. J., 1984, Water-use computer programs for Florida: U.S. Geological Survey Open-File Report 84-442.

REPORIS RELEASED:

Healy, H. G., Public water supplies of selected municipalities in Florida, 1976: (tables only, open filed).

1977, Public water supplies of selected municipalities in Florida, 1975: U.S. Geological Survey hater-Resources Investigations 77-53.

Leach, S. D., 1977, Water use inventory in Florida, 1975: U.S. Geological Survey Open-File Report 77-577.

1978, Source, use, and disposition of water in Florida, 1975: U.S. Geological Survey hater-Resources Investigations 78-17.

, 1978, Freshwater use in Florida, 1975: Florida Bureau of Geology Map Series 87 .

Duerr, A. D., and Trommer, J. T., 1979, Estimated water use in the Southwest Florida Water Management District, and adjacent areas: U.S. Geological Survey Open-File Report 81-56.

Ieach, S. D., and Healy, H. G., 1980, Estimated water use in Florida, 1977: U.S. Geological Survey Water-Resources Investigations 79-112.

Duerr, A. D., and Trommer, J. T., 1981, Estimated water use in the Southwest Florida Water Management District and adjacent area, 1980: U.S. Geological Survey Open-File Report 81-1060.

Leach, S. D., 1982, Estimated water use in Florida, 1980, Florida Bureau of Geology Map Series 103.

Duerr, A. D., and Trommer, J. T., 1983, The benchmark farm program--a method for estimating irrigation water use in southwest Florida: U.S. Geological Survey Water-Resources Investigation 82-17.

Duerr, A. D., and Sohm, J. E., 1983, Estimated water use in southwest Florida 1981, and summary of water use, 1970, 1975, and 1977-81: U.S. Geological Survey Open-File Report 83-45.

Leach, S. D., 1983, Consumptive use of freshwater in Florida, 1980: Florida Bureau of Geology Map Series 105.

1983, Source, use and disposition of water in Florida, 1980: U.S. Geological Survey Water-Resources Investigation 82-4090.

Spechler, R. M., 1983, Estimated irrigation water use in Florida, 1980 Florida Bureau of Geology Map Series 106. 
DATE PROJECT_BEGAN: July 1964

DATE PROJECT ENGS: Continuing

PRINCIPAL INVESTIGATOR: W. C. Bridges, Tallahassee

COOPERATING AGENCY: Florida Department of Transportation

PROBLEM: Local and state governments, highway designers, planners, and zoning commissions have a responsibility to avoid uneconomic, hazardous or incompatible use and development of the state's flood plains. Prime requisites to meet these criteria are a knowledge of the flood flow characteristics of streams and the ability to make reliable estimates of the flood magnitude and frequency.

OBJECIIVE: To assess the hydraulic and hydrologic characteristics of Florida streams. To collect flood flow data and analyze hydraulic problems for selected stream reaches as well as for hydrologic regions. To document and prepare reports for extreme flood events.

APPROACH: Expand the flood peak data base by maintaining a regional network of crest-stage gages. These data will supplement the statewide gaging station network.

Update and maintain the computer files for basin characteristics and peak flow for use in regional flood frequency analysis.

Respond by letter reports to specific requests for hydraulic and hydrologic information for selected stream reaches.

Assess extreme flood events, including indirect flood measurements, analysis, and preparation of reports to disseminate the flood information.

PROGRESS \& SIGNIFICANT RESULIS: A report was completed which described the water-level fluctuations of the U.S. Highway 90 closed basin retention pond in Madison. This report provides a technique for simulating net monthly change in pond elevation in response to rainfall and evaporation. A rainfall/runoff gaging station was installed to provide data for a rainfall response model for this closed basin.

A multiple opening bridge crossing of the Escambia River (drainage area 3,817 square miles) and the proposed road re-alignment was analyzed.

Dimensionless hydrographs were defined for $30 \mathrm{small}$ basin sites for use in the development of a statewide dimensionless hydrograph for ungaged sites. 
RLANS FOR THIS YEAR: Dimensionless hydrographs for selected larger basins (50-300 square miles) will be computed for use in the development of a statewide dimensionless hydrograph for ungaged sites. A report will describe the results. Assessment of floods and flooding potential will be made on a request basis.

REPORIS REIEASED:

Bridges, W. C., 1972, Effects of Port Orange Bridge-causeway on flow of Halifax River, Volusia County, Florida: U.S. Geological Survey, Florida District, Open-File Report 72-005.

, 1974, An analysis of 1972-73 floods on Monroe Street and St. Augustine Branch, Tallahassee, Florida: U S Geological Survey, Florida District, Open-File Report 74-023.

, 1982, Technique for estimating magnitude and frequency of floods on natural-flow streams in Florida: U.S. Geological Survey, Florida District, Open-File Report 74-023.

, 1985, Analysis of water-level fluctuations of the U.S. Highway 90 retention pond, Madison, Florida: U.S. Geological Survey WaterResources Investigations Report 85-4057.

Bridges, W. C., and David, D. R., 1972, Floods of September 20-23, 1969, in the Gadsden County area, Florida: Florida Dept. of Natural Resources, Bureau of Geology Information Circular 79. 
DATE PROJECT BECAN： September 1963

DATE PROJECT ENDS: Continuing

PROJECT_COORDINATOR: Walter R. Aucott, Tallahassee

COOPERATING_AGENCY: Florida Department of Environmental Regulation

PROBLEM: Water-use planners have repeatedly expressed the need for maps that show the characteristics and availability of water in Florida or that show related information such as climate. Prior to the start of this project only a few maps had been published that give hydrologic data or other data closely related to hydrologic problems in Florida.

OBJECIIVE: This project seeks to make available the needed information in the form of a water atlas-a series of map reports designed to furnish to the user generalized hydrologic, geologic, and related information, portrayed graphically on a standard size map. These maps are most useful for broad planning to aid legislators, planners, industrialists, laymen, and others as well as hydrologists to provide readily available hydrogeologic information for decision making.

APPBOACH: Using available information and knowledge from other statewide studies maps portraying aspects of the hydrologic cycle will be prepared by the U.S. Geological Survey and published by the cooperating agency.

PROGRESS \& SIGNIFICANI RESUIIS: Since the inception of this project, a total of 54 atlas series maps have been published. These maps have benefitted people in both technical and non-technical disciplines.

PLANS FOR_THIS_YEAR: Complete reports in progress and begin two new reports.

REPORTS IN PROCESS:

Foose, D. W., Long-term lake stations in Florida, 1984

Rumenik, R. P., Runoff in hydrologic units in Florida

REPORIS REIEASED:

Healy, H. G., 1962, Piezometric surface of the Floridan aquifer in Florida, July 6-17, 1961: Florida Bureau of Geology Map Series 1. , 1962, Piezometric surface and areas of artesian flow of the Floridan aquifer in Florida, July 6-17, 1961; (Revised 1975): Florida Bureau of Geology Map Series 4.

Calver, J. L., 1965, Mineral resources and industries of Florida: Florida Bureau of Geology Map Series 8.

Shampine, W. J., 1981, Chloride concentration in water from the upper part of the Floridan aquifer in Florida: (Revised 1975), Florida Bureau of Geology Map Series 12. 
Shampine, W. J., 1965, Hardness of water from the upper part of the Floridan aquifer in Florida, (Revised 1975): Florida Bureau of Geology Map Series 13.

_. 1965, Dissolved solids in water from the upper part of the Floridan aquifer in Florida, (Revised 1975): Florida Bureau of Geology Map Series 14. , 1965, Sulfate concentration in water from the upper part of the Floridan aquifer in Florida; (Revised 1975): Florida Bureau of Geology Map Series 15.

Hyde, L. W., 1965, Principal aquifers of Florida; (Revised 1975): Florida Bureau of Geology Map Series 16.

Vernon, R.O., Puri, H.S., 1964, Geologic map of florida: Florida Bureau of Geology Map Series 18.

Kenner, W. E., 1966, Runoff in Florida: Florida Bureau of Geology Map Series 22.

Kenner, W. E., Pride, R.W., Conover, C.S., 1967, Drainage basins in Florida: Florida Bureau of Geology Map Series 28.

Kenner, W. E., 1969, Seasonal variation of streamflow in Florida: Florida Bureau of Geology Map series 31.

Visher, F. N., Hughes, G.H., 1969, The difference between rainfall and potential evaporation in Florida, (Revised 1975): Florida Bureau of Geology Map Series 32 .

Raufman, M. I., 1969, Generalized distribution and concentration of orthophosphate in Florida streams, (Revised 1975): Florida Bureau of Geology Map Series 33.

Kenner, W. E., Hampton, E. R., Conover, C. S., 1969, Average flow of major streams in Florida, (revised 1975): Florida Bureau of Geology Map Series 34.

Kaufman, M. I., 1969, Color of water in Florida streams and canals: Florida Bureau of Geology Map Series 35 (revised 1975).

Pride, R. W., 1970, Estimated water use in Florida, 1965, (Revised 1975): Florida Bureau of Geology Map Series 36.

Kaufman, M. I., 1970, The $\mathrm{pH}$ of water in Florida streams and canals: Florida Bureau of Geology Map Series 37.

Hughes, G. H., Hampton, E. R., Tucker, D. F., Annual and seasonal rainfall in Florida: Florida Bureau of Geology Map Series 40 (reprinted 1976).

Klein, H., Depth to base of potable water in the Floridan aquifer: Florida Bureau of Geology Map Series 42.

Anderson, W., Temperature of Florida streams: Florida Bureau of Geology Map Series 43.

Vernon, R. O., 1973, Top of the Floridan artesian aquifer: Florida Bureau of Geology Map Series 56.

Slack, L. J., Raufman, M. I., 1973, Special conductance of water in Florida streams and canals, (Revised 1975): Florida Bureau of Geology Map Series 58.

Hughes, G. H., 1974, Water-level fluctuations of lakes in Florida: Florida Bureau of Geology Map Series 62.

Rosenau, J. C., and Faulkner, G. L., An index to springs of Florida: Florida Bureau of Geology Map Series 63. 
Stone, R. B., 1974, Low streamflow in Florida--magnitude and frequency: Florida Bureau of Geology Map Series 64.

Healy, H. G., 1974, The doservation-well network of the U.S. Geological Survey in Florida: Florida Bureau of Geology Map Series 65.

Snell, L. J., and Kenner, W. E., 1974, Surface water features of Florida: Florida Bureau of Geology Map Series 66 .

Pascale, C. A., Estimated yield of fresh-water wells in Florida: Florida Bureau of Geology Map Series 70.

Healy, H. G., 1975, Terraces and shorelines of Florida: Florida Bureau of Geology Map Series 71 .

Conover, C. S., and Leach, S. D., 1975, River basin and hydrologic unit map of Florida: Florida Bureau of Geology Map Series 72.

Healy, H. G., 1975, Potentiometric surface and areas of artesian flow of the Floridan aquifer in Florida, May 1974: Florida Bureau of Geology Map Series 73.

Causey, L. V., Leve, G. W., 1976, Thickness of the potable-water zone in the Floridan aquifer, Florida Bureau of Geology Map Series 74.

Slack, L. J., Goolsby, D.A., 1976, Nitrogen loads and concentrations in Florida streams: Florida Bureau of Geology Map Series 75.

Slack, L. J., 1977, Program for monitoring surface-water quality in Florida: Florida Bureau of Geology Map Series 76.

Dysart, J. E., Goolsby, D. A., 1977, Dissolved-solids concentrations and loads in Florida surface waters: Florida Bureau of Geology Map Series 77.

Dysart, J. E., 1978, Satellite image mosaic NASA ERTS-1 imagery-1973: U.S. Geological Survey Misc. Invest. Maps.

Hughes, G. H., 1978, Runoff from hydrologic units in Florida: Florida Bureau of Geology Map Series 81 .

Phelps, G. G., 1978, Chemical quality of water used for municipal supply in Florida, 1975, Florida Bureau of Geology Map Series 82. , 1978, Principal uses of freshwater in Florida, 1975: Florida Bureau of Geology Map Series 83.

Leach, S. D., 1978, Freshwater use in Florida, 1975: Florida Bureau of Geology Map Series 87.

Hull, R. W., Irwin, G. A., 1979, Quality of untreated water for public supplies in Florida with reference to the National Primary Drinking Water Regulations: Florida Bureau of Geology Map Series 91.

Miller, J. A., 1979, Potential subsurface zones for liquid waste storage in Florida: Florida Bureau of Geology Map Series 94.

Slack, L. J., Rosenau, J.C., 1979, water quality of Florida springs: Florida Bureau of Geology Map Series 96.

Stewart, J. W., 1980, Areas of natural recharge to the Floridan aquifer in Florida: Florida Bureau of Geology Map Series 98.

Healy, H. G., 1981, Estimated pumpage from ground-water sources for public supply and rural domestic use in Florida, 1977: Florida Bureau of Geology Map Series 102.

Leach, S. D., 1982, water use in Florida, 1980: Florida Bureau of Geology Map Series 103. 
Healy, H. G., 1982, Potentiometric surface of the Floridan aquifer, May 1980: Florida Bureau of Geology, Map Series 104.

Leach, S. D., 1982, Consumptive water use in Florida, 1980: Florida Bureau of Geology Map Series 105.

Spechler, R. M., 1983, Estimated irrigation water use in Florida, 1980: Bureau of Geology Map Series 106.

Foose, D. W. and Sohm, J. E., 1983, An index to long term surface water sites in Florida: Florida Bureau of Geology Map Series 107.

Leach, S. D., 1984, Projected public supply and rural (self-supplied) water use in Florida through year 2020: Florida Bureau of Geology Map Series 108.

Hampson, P. S., 1984, Wetlands in Florida: Florida Bureau of Geology Map Series 109.

Sinclair, W. C. and Stewart, J. W., 1985, Sinkhole type, development, and distribution in Florida: Florida Bureau of Geology Map Series 110. 
DATE PROJECT BEGAN: October 1970

DATE PROJECT ENDS: Continuing

PRINCIPAL INVESTIGATIOR: J. J. Hickey, Tampa

COOPERATING AgENCY: Federal Program

PROBLFY: Liquid wastes are now being injected into saline water in the deeper zones of the Floridan aquifer with indication of expanded use of the aquifer waste-storage capacity, especially in regard to storingdisposing of secondary treated sewage effluent. The hydrologic and geochemical characteristics are not adequately known to effectively evaluate the potentialities and possible consequences of subsurface waste storage. Based on the present state of knowledge, reliable prediction of the movement, chemical interactions, and ultimate fate of liquid wastes underground is uncertain.

OBJECPIVE: To provide the needed scientific information base and guidelines for a comprehensive evaluation of the lithology, hydrology and geochemistry of the deep saline parts of the aquifer systems, and for planning-management decisions among a multiplicity of possible uses of the saline aquifers, including subsurface liquid waste storage. The investigation is coordinated with the geologic research phase being conducted by the Florida Bureau of Geology.

APPROACH: Assessment and synthesis of available hydrologic and geochemical data into a regional appraisal of the deep saline-water part of the aquifer system; inventory, assessment and evaluation of active and planned subsurface waste disposal systems in Florida, compilation of data, field investigations, and preparation of summary report including case studies, and establishment of a foundation for expanded effort in subsequent years via liaison with regulatory agencies, consultants, companies, the Florida Bureau of Geology and WRD research personnel.

RROGRESS \& SIGNIFICANI RESUIIS: The Water Supply Paper was approved for publication and is in the process of being prepared for printing. The journal article was submitted to GROUNDWATER for publication. Two additional reports received colleague review and both are being submitted for Director's approval. An invited talk was presented at a NWWA symposium on Regional Aquifer Systems.

PLANS FOR THIS YEAR: Guide saltwater convection and drainage well reports through the review and approval process. Begin reports dealing with subsurface injection in south Florida and hydrogeologic factors that influence saltwater convection during subsurface injection. 
REPORTS IN PROCESS:

Hickey, J. J., Convection of saltwater during injection of liquid waste; Journal Article.

German, E. R., Drainage well inflow to the Floridan aquifer system from two lakes in Orlando, Florida; U.S. Geological Survey Water-Resources Investigations.

REPORTS RETEASED:

Kaufman, M. I., 1973, Subsurface wastewater injection, Florida: Amer. Soc. Civil Engineers, Proc. Paper 9598, vol. 99, no. IRI, p. 53-70. Goolsby, D. A., 1972, Geochemical effects and movement of injected industrial waste in limestone aquifer: Amer. Assoc. Petroleum Geologists Memoir 18, p. 355-368.

Raufman, M. I., Goolsby, D. A., and Faulkner, G. L., 1973, Injection of acidic industrial waste into a saline carbonate aquifer: Geochemical aspects: Amer. Assoc. Petroleum Geologists, Underground Waste Management and Artificial Recharge, vol. 1, p. 526-551.

Wilson, W. E., Rosenshein, J. S., and Hunn, J. D., 1973, Hydrologic evaluation of industrial waste injection at Mulberry, Florida: Amer. Assoc. Petroleum Geologists, Underground Waste Management and Artificial Recharge, vol. 1, p. 552-564.

Puri, H. S., Faulkner, G. L., and Winston, G. O., 1973, Hydrogeology of subsurface liquid waste storage in Florida: Amer. Assoc. Petroleum Geologists, Underground Waste Management and Artificial Recharge, vol. 2, p. 825-850.

Meyer, F. W., 1974, Evaluation of hydraulic characteristics of a deep artesian aquifer from natural water-level fluctuations, Miami, Florida: Florida Bur. of Geology, Rept. of Inv. No. 75, 32 p.

Faulkner, G. L., and Pascale, C. A., 1975, Monitoring regional effects of pressure injection of wastewater in a limestone aquifer: Ground water, Vol. 13, No. 2, p. 197-208.

Kaufman, M. I., and McKenzie, D. J., 1975, Upward migration of deep-well waste-injection fluids in Floridan aquifer, south Florida: U.S. Geological Survey Journal Research, Vol. 3, No. 3, 261-271.

Pascale, C. A., I976, Construction and testing of two waste-injection monitor wells in northwest Florida: U.S. Geological Survey Open-File Rept. 76-1, $42 \mathrm{p}$.

Pitt, W. A., Jr., and Meyer, F. W., 1976, Ground-water quality at the site of a proposed deep-well injection system for treated waste-water, West Palm Beach, Florida:U.S. Geological Survey Open-File Rept. 76-91, 43 p.

McKenzie, D. J., 1976, Injection of acidic industrial waste into the Floridan aquifer near Belle Glade, Florida: Upward migration and geochemical interaction 1973-75: U.S. Geological Survey Open-file Rept. $76-626,54 \mathrm{p}$.

Wilson, W. E., 1976, Hydrologic data for a subsurface waste-injection site at Mulberry, Florida 1972-75: U.S. Geological Survey Open-File Rept. $76-721,24 \mathrm{p}$.

Pascale, C. A., and Martin, J. B., 1977, Hydrologic monitoring of a waste injection well near Milton, Florida: U.S. Geological Survey Open-File Rept. 77-368, 46 p. 
(FL-154)

Wilson, W. E., 1977, Hydrologic data for a subsurface waste injection site, Mulberry, Florida, 1972-76: U.S. Geological Survey Open-File Rept. 77$511,24 \mathrm{p}$.

Pitt, W. H., Meyer, F. W., and Hull, J. E., 1977, Disposal of salt-water during well construction: Problems and solutions: Ground-water, vol. 15, no. 4, p. 276-283.

Pascale, C. A., and Martin, J. B., 1978, Hydrologic monitoring of a deepwell waste injection system near Pensacola, Florida, March 1970-March 1977: U.S. Geological Survey Water Resources Inv. 78-27, 61 p.

Beaven, T. R., and Meyer, F. W., 1978, Well inventory and data summary for the Floridan aquifer system in Dade and Monroe Counties: U.S. Geological Survey Open-File Rept. OF 78-881, 26 p.

Ehrlich, G. G., Godsy, E. M., Pascale, C. A., and Vecchioli, John, 1979 Chemical changes in an industrial waste liquid during post-injection movement in a limestone aquifer: Pensacola, Florida, Ground Water, vol. 17 , no. 6, p. 562-573.

Vecchioli, John, 1979, Monitoring of subsurface injection of wastes, Florida: Ground Water, vol. 17, no. 3, p. 244-249.

Miller, J. A., 1979, Potential subsurface zones for liquid-waste storage in Florida: Florida Bureau of Geology, Map Series 94, 1 sheet.

Meyer, F. W., 1980, Disposal of liquid wastes in cavernous dolomites beneath southeastern Florida: Proceedings of the International Association of Hydrogeologists [in press].

Vecchioli, John, Ehrlich, G. G., Godsy, E. M., and Pascale, C. A., 1980, Alterations in the chemistry of an industrial waste liquid injected into limestone near Pensacola, Florida: Proceedings of the International Association of Hydrogeologists [in press].

Vecchioli, John, 1981, Subsurface injection of liquid waste in Florida, United States of America: Proceedings of the International Symposium on Ground-Water Quality, March 23-27, 1981.

Hickey, J. J., 1981, Hydrogeology, estimated impact, and regional well monitoring of effects of subsurface wastewater injection, Tampa Bay area, Florida: U.S. Geological Survey Water Resources Investigations 80-118.

Hickey, J. J., and Wilson, W. E., 1982, Results of deep-well injection testing at Mulberry, Florida: U.S. Geological Survey Water-Resources Investigations $81-75,15 \mathrm{p}$.

Hull, R. W., and Martin, J. B., 1982, Data on subsurface storage of liquid waste near Pensacola,, Florida, 1963-1980: U.S. Geological Survey OpenFile Report 82-689, 179 p.

Hickey, J. J., 1982, Hydrogeology and results of injection tests at wasteinjection test sites in Pinellas County, Florida: U.S. Geological Survey Water-Supply Paper 2183, 42 p.

Schiner, G. R., and German, E. R., 1983, Effects of drainage well recharge on quality of water of the Floridan aquifer in the Orlando area, central Florida: U.S. Geological Survey Water Resources Investigations Report 82-4094, p. 124.

Hickey, J. J., 1984, Subsurface injection of treated sewage into a salinewater aquifer-aquifer pressure buildup: Ground Water, v. 22, no. 1, p. 48-55. 
Hickey, J. J., and Ehrlich, G. G., 1984, Subsurface injection of treated sewage into a saline-water aquifer-water quality changes and potential for recovery of injected sewage: Ground Water, v. 22, mo. 4, p.397-405.

Hickey, J. J., 1984, Field testing the hypothesis of Darcian flow through a carbonate aquifer: Ground Water, V. 22, Mo. 5, p. 544-547.

Kimrey, J. O., and Fayard, L. D., 1984, Geohydrologic reconnaissance of drainage wells in Florida-an interim report: U.S. Geological Survey Water Resources Investigations Report 84-4021, 67 p.

McKenzie, P. J., and Irwin, G. A., 1984, Quality of water recovered from a municipal effluent injection well in the Floridan aquifer system, Pompano Beach, Florida: U.S. Geological Survey Water Resources Investigations Report 84-4100, 23 p.

Merritt, M. L., 1984, Digital simulation of the regional effects of subsurface injection of liquid waste near Pensacola, Florida: U.S. Geological Survey Water-Resources Investigations Report 84-4042, 73 p.

Hickey, J. J. and Vecchioli, J., 1985, Subsurface injection of liquid waste with emphasis on injection practices in Florida, U.S. Geological survey Water Supply Paper 2281 [in press]. 
FL-325 APPRAISAL OF THE SURFICIAL AQUIFERS OF THE

LOWER EAST COAST OF FLORIDA

DATE PROJECT BEGAN: October 1979

DATE PROJECT ENDS: September 1987

PRINCIPAL INVESTIGATOR: LeO Swayze, Miami

COOPERATING AGENCY: South Florida Water Management District

PROBLEM: Southeast Florida relies on ground-water sources for nearly all of its potable water supply. Hydrologists and water managers need geologic and hydrologic data for the study and management of the water resources in southeast Florida. There is a lack of sufficient information on the geologic and hydraulic characteristics of the surficial aquifer to delineate the aquifer and evaluate the total water resources.

OBJECIIVE: (1) Assess the areal and vertical hydraulic conductivity of the surficial aquifer of eastern Palm Beach County; (2) Produce an areal transmissivity map; and (3) improve understanding of ground-water flow system in three dimensions.

APPROACH: Approximately 15 test well sites will located in the high permeability zones of the surficial aquifer in Palm Beach County. Aquifer test wells will be drilled and developed in productive zones. Step-drawdown and drawdown-recovery aquifer tests will be conducted as well as multiple well tests to determine aquifer anisotrophy. Tests to determine vertical and horizontal hydraulic conductivity will conducted in surficial sands. The Hvorslev method of aquifer analysis will be used for calculating horizontal hydraulic conductivity of the sands.

PROGRESS \& SIGNIFICANT RESULIS: Completed draft of Broward County hydrogeology report and entered into review. Published the Broward County geologic report. Drilled and installed about 45 wells for aquifer tests or slug tests in Dade County and filled in a few gaps in Broward County. Developed all the wells, ran preliminary tests on the wells, designed and began the final tests. Put together six-inch pump system capable of 1000 gpm for the pumping tests and an air slug test/strip chart recorder/transducer system for the slug tests. Developed the clusters of wells installed at 31 sites in Dade County and did ow sampling in the wells for major inorganic, field parameters, $\mathrm{Fe}, \mathrm{Al}$, and $\mathrm{Mn}$, nutrients, $\mathrm{DOC}$, SOC, and selected trace metals. Designed a special sampler to handle redoxrelated constituents, dissolved gases, and organics, especially volatile organics. Field tested the sampler and continued improving the design. Prepared draft of $\mathrm{QW}$ report and entered into office review. Prepared detailed lithological descriptions of approximately 8000 feet of geologic samples from the 31 sites in Dade County. Prepared geologic sections and report and entered the report into the review process. 
PLANS EOR THIS YEAR: Complete review process and publish Broward County ground water hydrogeology report. Finish aquifer tests in Dade County, analyze and document the results. Compile water level data and prepare long-term water-level map. Prepare hydraulic conductivity sections of Dade County hydrogeology report and enter into review. Select approximately 15 sites for hydraulic testing in Palm Beach County. Drill test and observation wells. Hydraulic tests will be conducted and analyzed and a transmissivity map for eastern Palm Beach County will be drafted.

REPORIS IN PROCESS:

Howie, Barbara, Appraisal of the chemical characteristics of ground water in the surficial aquifer, Broward County, Florida: U.S. Geological Survey Water Resources Investigation.

Fish, John E., Hydrologic characteristics of the surficial aquifer system, Broward County, Florida: U.S. Geological Survey water Resources Investigation

Sonntag, Wayne, Chemical characteristics of ground water in the surficial aquifer system, Dade County, Florida: U.S. Geological Survey Water Resources Investigation.

Causaras, Carmen, Geology of the surficial aquifer system in Dade County, Florida: U.S. Geological Survey Water Resources Investigation.

Reports Released:

Causaras, Carmen, 1982, Annotated bibliography of the geology and hydrology of the surficial aquifer in Dade, Broward, and Palm Beach Counties, Florida: U.S. Geological Survey Open-File Report 82-154.

Sonenshein, R.S., Fish, J.E., Causaras, C.R., and Poore, D.M., 1982, Index hydrologic data for selected sites in Broward County, Florida, 19391980: U.S. Geological Survey Open-File Report 82-920.

Sonenshein, R.S., Fish, J.S., Causaras, C.R., and Butler, D., 1984, Index of hydrologic data for selected sites in Dade County, Florida, 1939-1980: U.S. Geological Survey Open-File Report 84-430.

Sonenshein, R.S., Fish, J.E., Causaras, C.R., and Lindenman, B., 1984, Index of hydrologic data for selected sites in Palm Beach County, Florida, 1939-1980: U.S. Geological Survey Open-File Report.

Causaras, Carmen, 1984, Geology of the surficial aquifer in Broward County, Florida: U.S. Geological Survey Water Resources Investigation 84-4068. 
FL-362 EVALUATION OF STORMNATERR DETENIION BASINS IN WEST-CENIRAL FLORIDA

DAIE RROJECT BEGAN: October 1980

DATE PROJECT ENDS: September 1990

PRINCIPAL INVESTIGATOR: Miquel A. Lopez, Tampa

COOPERATING AGENCIES: Cities of Clearwater and Tampa and Pinellas County

PROBLEM: Pinellas County is one of the most densely populated counties in Florida, and serious water quality problems in the Gulf of Mexico and Tampa Bay are caused by the increase in urban runoff. There is a need for data to evaluate the cost-effectiveness of the pollution control measures being planned to satisfy receiving water quality standards.

OBJECTIVE: To determine the effectiveness of runoff detention ponds in reducing suspended solids, nutrients, metals, BOD, and coliform loading entering receiving waters from urban areas in Pinellas County.

APPROACH: Runoff quantity and quality of an urban watershed will be monitored for a year before the construction of a stormwater detention pond just upstream from the monitoring station. This will provide background information to compare with data after the completion of the pond in the second year. After completion of the pond, an additional monitoring station will be operated at the inflow. Loads entering and leaving the pond will be compared. An interpretive report will be written in the third year after at least one complete year of inflow and outflow data have been analyzed.

PROGRESS \& SIGNIFICANT RESULTS: Daily discharge and storm runoff water quality were monitored at the inflow and outflow of Alligator Creek in Clearwater, Kirby Street, and 29th Street storm drains in Tampa, and St. Joes Creek near St. Petersburg, Florida. An electromagnetic flow meter and automatic water-quality sampler were installed at 29th Street storm drain. Base flow samples were collected quarterly and storm runoff samples were collected by automatic samplers at all sites. Chemical analysis were made for metals (copper, chronium, lead, mercury, and zinc); nutrients (total nitrogen, organic nitrogen, nitrate, nitrite, total phosphorous and orthophosphorous), BOD, and COD.

PLANS FOR THIS YEAR: Discontinue rainfall, runoff, and water-quality data collection at Kirby Street storm drain. Install rainfall, runoff, and water-quality data collection equipment at the inflow to Detention Area Two on St. Joe's Creek near St. Petersburg, Florida. Continue data collection and processing. Compute storm loads of metals, nutrients, BOD, and COD of inflow and outflow at Alligator Creek flood detention area. 
FL-376 EFFECIS OF URBAN DEVELOPMENT ON THE HYDROLOGY

OF COASTAL AREAS OF FLORIDA

DATE PROJECT BEGAN: February 1981

DATE PROJECT ENDS: September 1986

PRINCIPAL INVESTIGATIOR: K. W. Causseaux, Tampa

COOPERATING AGENCY: Federal Program

PROBLEM: Recent studies completed by U.S. Geological Survey and consultants provide information about the impact of urban development on water quality that needs to be given wider public exposure. Administrators, planners and the public need to be aware of the cause and effect relationship between urban development and water resources.

OBJECTIVE: Present information about the relation of land use to hydrology of west-central Florida.

APPROACH: Prepare a report to describe the magnitude and frequency of flooding in the upper Sweetwater Creek basin, delineate areas inundated by the 100-year flood, and compute profiles for existing and selected future conditions.

PROGRESS \& SIGNIFICANI_RESUIIS: Preparation of report was resumed in July 1985 after additional funds became available. Some additional data were compiled in preparation for final revisions in report.

PLANS FOR THIS YEAR: Complete collection and compilation of additional data. Revise and publish final report.

RERORTS IN PROCESS:

Causseaux, K. W., the effects of development on flooding in the Sweetwater Creek basin of Hillsborough County, Florida: U.S. Geological Survey Water Resources Investigation. 
FL-377 ENIRONMENTAL ASSESSMENT STUDY OF THE CHARLOTTE HARBOR

ESTUARINE SYSTEM AND SURROUNDING AREA,

SOUTHWEST FLORIDA

DATE PROJECT BEGAN: JulY 1982

DATE PROJECT ENDS: June 1989

PRINCIPAL INVESTIGATOR: $\quad$ B. F. McPherson, Tampa

COOPERATING AGENCY: Florida Department of Environmental Regulation

PROBLEM: The area surrounding the Charlotte Harbor estuarine system is undergoing rapid development and population growth. As development occurs, surface-drainage features will be modified, and area water resources will undergo increased stress from water-supply withdrawals and waste disposal. Consequently, the magnitude of freshwater inflow to the estuarine system will be reduced and the inflow patterns altered. Saltwater may move upstream on principal tributaries and into surficial and intermediate aquifer systems, and salinity in the estuarine system may increase. Altered inflow patterns and increased chemical constituent loads will affect physical, chemical, and biological processes in the estuarine system.

OBJECTIVE: To determine existing conditions and evaluate the impact of future development on water-related resources of the Charlotte Harbor estuary. Specific objectives are to evaluate - (1) Freshwater runoff in the major tributaries and salinity distribution in the estuary. (2) Land and water use in the basin. (3) Material transport and water-quality characteristics in the major tributaries. (4) Circulation, flushing, and transport characteristics of the estuarine system. (5) Water-quality characteristics of the estuarine system, including physical, optical, chemical, radiochemical, and biological properties. (6) Relationships between freshwater runoff, nutrient loading, and water-quality characteristics in the estuarine system.

APPROACH: Information will be gathered from the existing literature and from field data collected to define and describe the estuarine system so as to meet the objectives listed above. Available information includes - (1) numerous scientific and technical reports, maps, etc.; and (2) rainfall, temperature, streamflow, water-quality, stream channel cross-sections, tide stage and velocity, water-use, land-use, topography, and hydrologic data. However, much additional biologic and hydrologic data will be required to meet study objectives. Evaluation will require application of various engineering and hydrologic methods including digital models that simulate hydraulic and water-quality conditions in streams and estuaries. 
(FL-377)

PROGRESS \& SIGNIFICANT_RESULTS : Collection, compilation, and analysis of physical, chemical, radiochenical, and biological data in the Charlotte Harbor estuarine system continued. An evaluation of trends in water quality and freshwater inflow was made. Calibration continued on the onedimensional flow and transport models in the tidal Peace River. Development of a two-dimensional and a three-dimensional hydrodynamic model continued. Analyses of benthic invertebrate data were completed. Water-quality data collected over the last 2 years were summarized in a report.

PLANS_EOR THIS YEAR: Collection, compilation, and analysis of physical, chemical, radiochemical, and biological data will continue. Evaluation of trends in land cover and land use, freshwater inflow, and water quality will be completed. Development and calibration of flow and circulation models will continue.

REPORIS RETEASED:

Stoker, Yvonne E. and Karavitis, George A., 1983, Literature assessment of the Charlotte Harbor Estuarine System and surrounding area, southwest Florida

Stoker, Yvonne E., 1985, hater quality of the Charlotte Harbor estuarine system, November 1982 through October 1984. Open-file report.

Estevez, E. D., 1985, Infaunal macroinvertebrates of the Charlotte Harbor estuarine system and surrounding inshore waters, Florida: water Resources Investigation Report 85-4260. 
FL-381 REAERATION CAPACITY OF STREAMS AND ESTUARIES

IN FLORIDA

DATE PRQJECT BEGAN: October 1981

DATE PROJECT ENDS: September 1986

RRINCIPAL INVESTIGATOR: John E. Coffin, Jacksonville

COOPERAIING AGENCY: Florida Department of Environmental Regulation

PROBLEM: The level of treatment of domestic and industrial sewage and resulting design of sewage treatment facilities is largely dependent on the organic waste assimilation capacity of the receiving water body. Waste assimilation capacity is in turn affected by the reaeration of these receiving waters at the air-water interface. Formulas have been developed for nationwide use, and at best, yield only approximations of actual reaeration coefficients of in-stream conditions.

OBJECTIVE: To familiarize District personnel, and personnel from the Florida Department of Environmental Regulation (FDER) with the modified tracer technique (using hydrocarbon gases of low molecular weight and rhodamine WT (Water Tracer) dye); to experiment with the modified tracer technique and its application and reliability in various hydrologic settings; and to formulate a data base for use in developing regional equations for estimating the reaeration coefficients of various water bodies in Florida.

APPROACH: Initially small streams will be studied to familiarize personnel with techniques. Once trained, the survey will be expanded to include larger rivers, estuaries and impounded rivers. Results will be compared to theoretical and empirical formulas used by FDER. A data base will be formulated and maintained pertinent to each reach or site. Regression analysis will be performed to develop regional equations for estimating reaeration coefficients for unmeasured streams and estuaries.

PROGRESS \& SIGNIFICANI RESUInS: Time-of-travel and reaeration studies were conducted on the Withlacoochee River, Alphia River, Strawberry Creek and Silversmith Creek. All studies were conducted under low-flow conditions. Results are considered very good.

PLANS FOR THIS_YEAR: Enter data into data base and evaluate using a statistical approach available from P-STAT or SAS. 
FL-393 FLOW CHARACTERISTICS OF NASSAU RIVER BASIN AND ESTUARY

$\begin{array}{ll}\text { DATE PROJECT BEGAN: } & \text { October } 1981 \\ \text { DATE PROJECT ENDS: } & \text { September } 1987\end{array}$

PRINCIPAL INVESTIGATOR: John E. Coffin, Jacksonville

COOPERATING AGENCY: St. Johns River Water Management District

PROBLEM: To evaluate the impact of future development in the Nassau River Basin, basic hydrologic data are needed. Modifications to biological systems may occur because of changes in salinity distributions. These modifications could have long-term, detrimental effects on the ecological balance of estuarine systems. To properly manage and conserve freshwater resources and to maintain an ecological balance, an understanding of the relation between saltwater movement and freshwater inflow to estuaries is needed. Specifically needed are continuous records of discharge, volume, direction of flow, velocity, water temperature, specific conductance, dissolved oxygen, and pH.

OBJECIIVE: The possibility of making maximum use of the land and water areas without upsetting the ecological balance hinges upon sufficient knowledge of the system. This study will provide information on the surface-water movement and water quality in the Nassau Estuary. The comprehensive information gained from the study will afford us the opportunity to begin to understand the processes of work in an estuary system. Most importantly this baseline knowledge can be transferred to neighboring estuaries.

APPROACH: The first phase is a basin reconnaissance, temporary gage installation, data collection and evaluation. Phase two includes equipment installation, basic data collection and evaluation, development and calibration of a one-dimensional flow model, and preparation of an interpretive report.

PROGRESS \& SIGNIFICANT RESULIS: Stage data were collected at five stations, and discharge data at three stations in the basin. Two mini monitors, collecting temperature and conductance data were installed. Rainfall data collected at four sites were processed and reviewed.

PIANS FOR THIS YEAR: Continue to operate and store information collected from the data network. Analysis of data will be completed using P-STAT. Additional estuarine bathymetry will be collected. The BRANCH model will be evaluated as a method to determine discharge for the Nassau River. 
FL-394 WETLAND ECOSYSTEM RECLAMATION AFTER PHOSPHATE MINING, WEST-CENIRAL FLORIDA

DATE PROJECT BEGAN: MaY 1982

DATE PROJECT ENDS: September 1988

PRINCIPAL INVESTIGATOR: T. H. Thompson, Tampa

COOPERATING AGENCY: Florida Institute of Phosphate Research

PROBLFM: Approximately 15 percent of Florida's phosphate reserves lie beneath wetlands. Current regulations prohibit mining wetlands. Data are not available on the potential for successful reestablishment of a wetlands ecosystem in an area that has been mined. A 25-acre wetlands test site has been selected for mining and restoration. The U.S. Bureau of Mines is developing various mining schemes for removing overburden and restoring the land. The U.S. Fish and Wildlife Service is developing revegetation methods to restore the wetlands flora. The U.S. Geological Survey (USGS) will define the pre- and post-mining hydrologic and biologic conditions at the site.

OBJECPIVE: (1) To develop, test, refine, and implement an integrated hydrologic and biological monitoring system that is sensitive enough to detect differences between pre- and post-mining conditions in a wetlands area that has been carefully reclaimed; (2) to use the monitoring system on an unmined and a reclaimed wetland site to determine hydrologic and biological variables that may affect the initial success or failure of a wetlands revegetation effort; and (3) to provide a base for evaluating longterm evolution of the wetlands hydrology and biology following reclamation and revegetation.

APPROACH: Seven major field activities will be coordinated to define preand post-mining conditions. They include (1) Botanical - aerial and field inspection of major vegetative groups; (2) Soil survey and analysis - define areal variation in soil horizons, (3) Topographical - land elevation contouring to define slopes and major changes from mining, (4) Ground water - define aquifers' thickness, extent, hydraulics, and water levels, (5) Surface water - gage streams and define high- and low-flow characteristics and percent of time soil is saturated, (6) Water quality - sample surface and ground water, and (7) Atmospheric data - measure quantity and quality of rainfall.

PROGRESS \& SIGNIFICANI RESUIIS: Collection of hydrologic and biologic data at the control basin and undisturbed portions of the test basin continued. About 16 acres that were formerly wetlands at the test basins were filled and brought back to premining grade. Approximately 40 acres have been partially filled with sand tailings but have not been regraded to premining levels. Four ground-water monitor wells were installed on the regraded lands and a stage-recorder installed in the pond adjacent to the wetlands. 
(FL-394)

PROGRESS \& SIGNIFICANT RESUIIS -- (continued)

Samples for quality analysis were collected from one of the new wells. Premining rainfall and runoff data have been processed for use on the USGSPRMS model. An annual summary of activities and request for continued funding was submitted to the cooperator.

PLANS FOR THIS YEAR: Continue to collect hydrologic and biologic data at control basin and undisturbed and regraded portions of test basin. Complete rainfall-runoff modeling of premining conditions at test basin. Complete installation of post-mining network when remainder of basin is regraded. Collect and analyze soil samples from regraded wetlands area for physical and chemical characteristics. 
FL-400 SALTWATER-INIRUSION MODELS FOR SELECTED AREAS, WEST-CENTRAL FLORIDA

DATE PROJECT BEGAN: October 1982

DATE PROJECT ENDS: September 1987

PRINCIPAL INNESTIGATOR: G. L. Mahon, Tampa

COOPERATING AGENCY: Southwest Florida Water Management District

PROBLEM: Pumpage from the Floridan aquifer has caused lowering of the potentiometric surface and has created a high potential for saltwater intrusion into the aquifer along Florida's Gulf Coast. With Florida's population expected to rise 30 to 50 percent between 1980 and 2000, an analysis of mechanisms for saltwater intrusion along the densely populated coastal area is necessary to plan for and manage the freshwater resources.

OBJECTIVE: The overall objective of the study is to better define the physics of coastal ground-water flow systems. Specific objectives are to (1) evaluate capability of cross-sectional digital models to simulate the saltwater-freshwater interface at three coastal sites; and (2) simulate movement of the interface under various stress conditions and evaluate impact of the movement on inland freshwater resources.

APRROACH: Existing geologic and hydrologic data will be evaluated. Additional wells will be drilled, accompanied by borehole geophysical logging, packer tests and water sampling. These data, together with lab tests of core samples, will provide information on the location and nature of the interface and porosity, water-level, and water-density data needed for the modeling effort.

PROGRESS \& SIGNIFICANI RESUIIS: Modifications to the input data and grid spacing of the Hernando County model gave an improved simulation of the saltwater-freshwater interface. A hypothetical pumpage stress of $120 \mathrm{mgd}$ caused Flux reduction to the flow system. When new 44 percent stresses were applied to the SUTRA model (run to a quasi-steady state condition), a maximum of 115 and 900-foot vertical and horizontal displacements, respectively, resulted. These displacements could cause freshwater-supply wells in the Aripeka area to experience increases in chloride concentration depending on well location, depth, and pumpage.

A second SUTRA simulation has begun along a 22-mile long cross section beginning in Tampa Bay, running perpendicular to equipotential lines and through ROMP well TR8-1 in Manatee County. Data from a previously calibrated cross-sectional flow model has been applied to the SUTRA model code, along with estimates of permeability for the saline areas. 
PIAANS_EOR_THIS_YEAR: Geologic, hydrologic, and water quality data will be collected during drilling of a new ROMP well near Rubonia in Manatee County. Instrumentation to collect continuous water level and conductivity measurements will be installed at the Hernando and Manatee County sites. Surface resistivity studies will be made in both areas to monitor the saltwater interface. Further development of the 2-D model in Manatee County will occur, along with testing the feasibility of expanding the 2-D model to three dimensions. A final report documenting modeling efforts at both sites will begin. 
FL-406 OOCURRENCE, MOVEMENT, AND FATE OF ORGANIC CONTAMINANIS

IN GROUND WATER NEAR PENSACOLA, FLORIDA (VICINITY OF

AMERICAN CREOSOTE, INC.)

DATE PROJECT BEGAN: October 1982

DATE PROJECT ENDS: September 1986

RRINCIPAL INVESTIGATOR: Bernard J. Franks, Tallahassee

COOPERAIING AGENCY: Federal

PROBLEM: American Creosote Works, Inc. (ACW), located in northwest Florida within the city limits of Pensacola, presents an opportunity to investigate the biodegradation of hazardous wastes and the feasibility of enhancement of aquifer restoration processes under one set of hydrogeologic conditions. During the 70 years of continuous operation, wastewaters generated from the use of creosote and PCP in the wood-treatment process were discharged into two unlined surface impoundments which are in direct contact with the sandand-gravel aquifer, the principal source of water in western panhandle Florida.

OBJECTIVE: (1) To delineate the hydrogeology of the study area in sufficient detail for development of a solute transport model that embodies the flow of nonconservative constituents; (2) to develop a ground-water flow model for the affected part of the aquifer; (3) to define the chemical constituents and the extent of contaminant movement in the aquifer; (4) to investigate impacts of organic contaminants on the nearshore environments in nearby Bayou Chico; and (5) to assist in the development of a solute transport model of contaminant movement, including both conservative and nonconservative constituents.

APPROACH: (1) Design, install, and operate a ground-water monitoring network. (2) Devise and test water-quality sampling methods, emphasizing collection and analyses of organic constituents. (3) Develop and test the hydraulic (ground-water flow) portion of the solute transport model. (4) Delineate contaminant plumes in the affected parts of the aquifer, based on the results of the above. (5) Coordinate concurrent research efforts concerned with microbially mediated processes related to biodegradation of hazardous wastes, field sampling, and laboratory analytical technique development in sampling for trace organic contaminants, and modeling of solute transport of both conservative and non-conservative constituents under field conditions.

PROGRESS \& SIGNIFICANT_RESULTS: Aquifer tests were conducted in model layers 1 and 2, and hydraulic and geologic properties of the aquifer determined. All hydrogeologic data have been compiled. A 3-D finitedifference ground-water flow model has been developed, and calibration begun. Papers were presented at two scientific meetings, and one journal article was published (Environmental Science and Technology). 
PLANS_EOR_THIS_YEAR: The ground-water flow model will be calibrated and documented. Water quality investigations will continue including coordinating district and research efforts related to sampling methodology, biodegradation, and transport of solutes.

REPORIS IN PROCESS:

Goerlitz, D. F., Troutman, D. E., Godsy, E. M., and Franks, B. J., 1985, Migration of wood preserving chemicals in contaminated ground water in a sand aquifer at Pensacola, Florida: Environmental Science and Technology (in review).

Franks, B. J., 1986, Organic contamination of a sand-and-gravel aquifer near Pensacola, Florida-I. Hydrogeology: USGS Prof. Paper (in process).

\section{REPORIS REIEASED:}

Mattraw, H. C. Jr., and Franks, B. J., editors, 1984, Movement and fate of creosote waste in ground water, Pensacola, Florida: U.S. Geological Survey toxic waste ground-water contaminated program: USGS, Open-File Report 84-466 (pending publication as a Water Supply Paper), 93 pp.

Franks, B. J., and Godsy, E. M., 1984, Creosote contamination of the sandand-gravel aquifer near Pensacola, Florida: Geological Society of America. Abstract with Programs, volume 16, Number 6, September 1984, p. 511 (abstract).

Franks, B. J., 1985, Organic contamination of the sand-and-gravel aquifer near Pensacola, Florida: Proceedings of the Southeastern Region Symposium on Water Quality, Jacksonville Beach, Florida, January 1985 (abstract). 
FL-408 HYDROLOGY AND WATER QUALITY OF PASCO COUNIY, FLORIDA

DATE PROJECT BEGAN: July 1983

DATE PROJECT ENDS: September 1986

PRINCIPAL INVESTIGATOR: J. D. Fretwell, Tampa

COOPERATING AGENCY: Pasco County

PROBLEM: Increasing demands are being made on water resources of Pasco county owing to rapidly increasing population for county use and export to metropolitan areas to the south. Four major well fields in the county pump more than 50 million gallons per day. A current study is needed to assess the water resources and to establish base-line water-quality data that will assist the county in planning and management.

OBJECIIVE: To appraise the water resources of Pasco County by defining the availability and quality of water resources, identifying areas of actual or potential contamination, and determining the effects of proposed groundwater withdrawals on the hydrologic system.

APPROACH: (1) To assemble and evaluate existing data and reports, (2) collect data, including a selected well inventory, an inventory of pumpage, lake reconnaissance, gaging of springflow and streamflow, geophysical logging, aquifer testing, water-quality sampling, and water-level measurements, (3) identify and quantify major discharge and recharge areas, (4) assess the potential for quality degradation as a result of existing and proposed land uses, (5) use available data in digital ground-water flow models to estimate the effects of stress at proposed ground-water development sites on the aquifer system, and (6) evaluate results and prepare a report.

PROGRESS \& SIGNIFICANI RESUIIS: Continued to collect, evaluate, and process data for report. Ten shallow wells were drilled to determine the thickness of surficial sands and depth of the water table. The surficial sands were found to be thin and dry in May throughout most of the eastern part of Pasco County. Half the wells contained water in September. Water-quality samples were collected at several sinkholes under low-flow conditions and again under high-water conditions. A ground-water flow model is being calibrated against known data for an average rainfall year 1976-77. A major part of the final report has been completed.

PLANS FOR THIS YEAR: Finalize calibration on the ground-water flow model. This includes changing constant-head boundaries to general-head boundaries in the Floridan aquifer. Input withdrawal for alternate development schemes to project potential drawdowns in the aquifer. Finalize first draft of the report and guide through review to approval. 
FL-410 ADAPTATION OF FLORIDAN AQUIFER SYSTEM RASA MODELS

FOR WATER-MANAGEMENT NEEDS, FLORIDA

DATE PROJECT BEGAN: October 1983

DATE PROJECT ENDS: Continuing

PRINCIPAL INVESTIGAIOR: C. H. Tibbals, Orlando

COOPERATING_AGENCIES: South Florida Water Management District, Southwest Florida Water Management District, St. Johns River, Water Management District, and Suwannee River Water Management District

PROBLEM: From 1950 to 1980, the population of Florida grew from about 2.8 million to about 9.8 million, an increase of 350 percent. By 2000 , the population is expected to grow to about 17 million. Population growth, plus that of industry and the increased use of ground water for crop irrigation has placed great demand on the ground-water resource. The principal source of fresh ground water is the Floridan aquifer system which underlies all of Florida and parts of Alabama, Georgia, and South Carolina. The effects of increased pumping of ground water have been responsible, in part, for lower pressure heads in the Floridan which, in turn, are responsible for intrusion of salty water along both the east and west coasts of peninsular Florida and along the Gulf coast of north-central Florida; lower lake levels; lower water levels in the surficial aquifer; reduced streamflow; and, to some degree, increased potential for sinkhole activity.

OBJECIIVE: The overall objective is to provide the basis for long-term liaison and, thus, coordination between the U.S. Geological Survey (USGS) and the five State Water Management Districts as regards refinement and uses of the regional and subregional Floridan aquifer computer models constructed during the now-completed Floridan Regional Aquifer Systems Analysis (RASA) projects; to provide information on new modeling techniques; and to provide, on an as-needed basis, general guidance and advice on matters that relate to ground-water modeling in general and ground-water hydraulics. Other, more specific, objectives are: (1) Identify data and investigate needs on an areal basis; (2) Suggest and help implement changes to existing models; (3) Help provide results of specific-purpose modeling runs done in cooperation with the Southeastern Region staff that maintains the regional model; (4) Participate in the development of a high resolution (small grid block), multi-District ground-water model data base; (5) Develop techniques to access that data base at any location so as to provide "moveable models," small models for any area that are, for the most part, already calibrated and that can be quickly constructed.

APPROACH: Liaison and coordination will be accomplished by means of both formal and informal meetings and discussions between the USGS District project leader, the Water Management District staffs, and the USGS Southeast Regional staff. Data and investigative needs will be assessed on a continuing basis by the USGS and the Water Management District staffs as the 
(FL-410)

Districts implement their respective water-management plans. Some of these needs will be identified as the USGS regional RASA model is called upon to furnish results of specific purpose modeling runs to determine various stress-effect relations. The high-resolution data base will be constructed by adapting and incorporating the data bases generated for the regional and subregional models. The USGS Trescott-Larson three-dimensional source code will be the first to be modified to access the data base. Later, the USGS McDonald-Harbaugh three-dimensional modular model will be modified. Programs will be written in Fortran 77 to be executed in interactive mode.

PROGRESS_\&_SIGNIFICANT_RESUITS: Distributed to all WMD's a working prototype of moveable model complete with preliminary master data files and modified 3D model. Placed programs and files in top-level Prime directory so that users can netlink to Orlando Prime and use moveable model. Distributed a report documenting the new modular 3D model. Added simulated springs to list of known springs, and partially updated water table master file. Conducted test model runs on selected areas; calibration is pretty good. Made numerous modifications to 3D model, and wrote several utility programs to facilitate editing of direct access-type master data files. Reviewed three SWFWMD model reports, and conducted followup review on same.

PLANS_FOR THIS YEAR: Continue to refine master data files. Write programs to extract water-use information from "flat-files" and prepare input pumping data matrices to model. Modify moveable model program to output data set for input to modular 3D model. 
FL-411 HYDROLOGIC EVALUATION OF THE POTENIIAL WATER SUPPLY OF THE INTERMEDIATE AQUIFER SYSTEM, SOUTHWEST FLORIDA

DATE PROJECT BEGAN: October 1983

DATE PROJECT ENDS: September 1987

PRINCIPAL INVESTIGATOR: A. D. Duerr, Tampa

COOPERATING AGENCY: Southwest Florida Water Management District

RROBLEM: West-central Florida is experiencing an explosive growth of population. To meet increased demands for water, there is a need to define the hydrogeology and water quality in the southern half of the Tampa Subdistrict. A recently completed study identified areas where data were too limited to adequately simulate the ground-water system. One area was to better define the hydrogeology and flow systems of the intermediate aquifer. The intermediate aquifers are the principal water-bearing units that contain radium-226 at levels that exceed five picocuries per liter. The hydrologic and geochemical factors that control the occurrence and distribution of radium-226 is not understood.

OBJECTIVE: To systematically evaluate the hydrogeologic characteristics and water quality of major water-bearing units of the intermediate aquifer system in southwest Florida. This will include the definition of groundwater basin boundaries, identification and quantitative evaluation of water use and discharge and recharge areas, and the definition and description of each water-bearing unit.

APPROACH: The nature of the interrelation of the aquifer units and their water-quality characteristics will be defined from the existing data, a selected well inventory, and necessary wells will be installed to supplement existing data. Individual water-bearing units will be identifred and sites selected for conducting packer tests, water-quality sampling, and aquifer tests. Potentiometric maps will be prepared to define the recharge and discharge areas. Major withdrawals will be identified and rates of pumpage determined.

PROGRESS \& SIGNIFICANI RESULIS: A preliminary observation well network was established to monitor water levels in the intermediate aquifer system. In September, water-level measurements were made in approximately 170 wells. Of these wells, 40 were measured by the Hydrologic Records Section, 20 by phosphate companies, and 110 by project personnel. A table was prepared showing well number, latitude and longitude, county, owner, use, depth, casing, diameter, land-surface elevation, and water level. Geophysical logs, including caliber, conductivity, and temperature, were run on 6 wells to define water-quality differences in various zones. 
PIANS FOR THIS YEAR: Construct a September 1985 potentiometric surface map of the intermediate aquifer system. Add additional wells to the network where needed. Develop a generalized description of the intermediate aquifer and confining units. Construct geologic sections through the study area to define the geologic setting. Measure water levels and construct a potentiometric surface map for May 1986. Complete a first draft of the final report. 
FL-412 SIMULATION APPROACHES TO UNDERSTANDING GROUND-

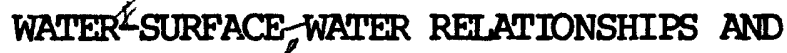

WATER BUDCEIS IN FLORIDA LAKES

DATE PROJECT BEGAN: October 1983

DATE PROJECT ENDS: September 1987

PRINCIPAL INVESTIGATOR: $\quad$ D. Briane Adams, Tampa

COOPERATING AGENCY: Southwest Florida Water Management District

PROBLEM: Water managers' responsibility to administer all water resources is hampered by multi-water use from residential and recreational use of surface water to agricultural-municipal-industrial use of water. With a mandate for equitable allocation of water resources, water managers need quantitative information that indicates the relationship between the lakessurficial aquifers and the Floridan aquifer to manage the public resource.

OBJECTIVE: (1) To define the influence of head in the Floridan aquifer on lake levels. (2) To gain a better understanding of the recharge process in the surficial aquifer. (3) To provide an accurate determination of evaporation and evaporation processes. (4) To provide a realistic water budget with error estimates for Lake Lucerne.

APPROACH: In cooperation with the National Research Program (NRP) Lake Hydrology Project headed by T.C. Winter, a detailed ground water-surface water-atmospheric-water relationship will be studied. Methods of analysis will include two-dimensional digital modeling of the lake-ground water system in cross-section for steady state and transient flow, and, depending upon results of the two-dimensional model, a three-dimensional model may be applied. The applicability of saturated-unsaturated model will be evaluated for future work. Evaporation will be calculated using energy budget techniques and compared to methods more generally used such as pan and mass transfer methods. The study of wind and vapor pressure profiles over the lake will also be studied as they relate to the evaporation process. Determination of the surface water component of the water budget is limited to overland flow and processes in this closed basin lake.

PROGRESS \& SIGNIFICANI RESUIIS: A land based climate station was installed on the northern shore of Lake Lucerne. The station includes conventional National Weather Service type instruments which are maintained by an observer, and continuously recording sensors which are relayed to a Campbell, CR21 datalogger. The datalogger monitors variables such as relative humidity, air temperature, wind speed, wind direction and isolation, and outputs hourly and daily summaries. 
The land station also contains a wet-dry precipitation collection for monitoring precipitation quality for acid rain research for Owen Bricker's NRP Project. An observer processes weekly precipitation samples from the wet-dry collector following NADP/NIN protocol. Sample pH has ranged from 3.9 to 5.3. Samples are processed in a small building located at the station which houses the laboratory equipment, and shipped to Denver Central Lab for analyses.

A second climate station was constructed and installed on a raft which is anchored mid-lake. The raft climate station is collecting about 750,000 pieces of information yearly. Readings include vertical profiles of wind speed and vapor pressure over the water surface to a height of 5 meters. A vertical profile of water temperature is measured by thermocouples which are located every foot in depth. Other sensors include a "coolie hat" thermocouple psychrometer and a pressure transducer for barometric pressure. These data are recorded by a Campbell CR2IX datalogger, and periodically retrieved on a cassette tape.

Long and shortwave radiation reflected from the water surface are recorded on a third datalogger (CR21) located at the recording gage for lake stage.

In order to store, verify, and manipulate the incoming raw data from the three dataloggers, a data entry system was designed and written. The data entry system is a menu-driven interactive program which allows the user to process and verify the data before they are entered into final storage in a P-STAT database. Options in the program include sorting the raw data, plotting and tabling data, and entering the data into the P-STAT Iibrary. The sorting option identifies each output with its proper parameter code and definition, and checks the value against a defined min-max range. The sorted flat file is the input for the tabling and plotting options. The plotting option uses TELEGRAPH plotting commands to create high quality, publishable plots of the raw data. The table option creates "daily values" type tables for each parameter which allows the easy review of the data. Corrections, deletions or modifications can then be made to the data as needed before requesting new plots, or entering the data into the P-STAT database.

A network of wells defining the water table and 3 piezometer test sites, with wells ranging from 7 to 155 feet in depth finished in the water table sand aquifer, clay confining layer and artesian (limestone) systems, were routinely monitored. The hours of pumpage of 8 irrigation wells in the deep artesian aquifer in a surrounding citrus grove have been monitored monthly. Preliminary review of the pumpage data shows a strong correlation between water levels in the piezometers above the assumed clay confining layer and below a chert layer identified in the presumed sand water table aquifer, and hours of pumpage at the closest irrigation well indicating a connection between the lower sand and the clay to the deep artesian aquifer (limestone). This layer of chert encountered during drilling at 50 feet appears to be an effective confining layer between the two aquifers. Upcoming aquifer tests will focus on the leakage characteristics of this layer. 
Additional routine data collection includes monthly water quality sampling of Lake Lucerne which indicates a very low alkalinity and is predominately sodium and sulfate. Groundwater quality has been sampled at one nest site. Review of these initial ground-water quality results indicate the primary interactions of the lake is with the shallow water table aquifer.

Unfunded work or assistance contributed to the project by others include: benthic and phytoplankton analysis by the cooperator (SWFWMD); clay mineralogy of core samples by x-ray diffraction by Florida Institute for Phosphate Research (FIPR); lake quality sampling for susceptibility to acid precipitation by EPA (National Acid Rain Survey); Polk County (not a cooperator) for nutrient sampling of lake and wells for a nutrient budget; Reith Slack (NRP) benthic community sampling; and technical assistance from Tom Winter (NRP) for lake-groundwater relationships.

PIANS FOR THIS YEAR: Continue monitoring of groundwater and atmospheric water. Complete a flow model of the lake, surficial and Floridan aquifer systems. Compute evaporative losses by the energy budget method. Begin water budget analysis of the system. Related activities external to the cooperative project include chemical quality of lake, groundwater and precipitation; biological research of benthic invertebrate commuities; research of evaporative methods including energy budget, mass transfer, eddy correlation, and evaporation pan, and study of near-shore ground-water flow systems. 
FL-413 IMPACT OF REDUCED FRESHWATER INFLOW ON THE SALINITY CHARACTERISTICS OF THE WITHIACOOCHEE RIVER ESTUARY

AND THE COASTAL RIVERS ESTUARINE ZONE OF CITRUS

AND HERNANDO COUNIIES, FLORIDA

DATE PROJECI BEGAN: October 1983

DATE PROJECT ENDS: September 1987

PRINCIPAL INVESTIGATOR: $\quad$ D. K. Yobbi, Tampa

Cooperating Agency: Southwest Florida Water Management District

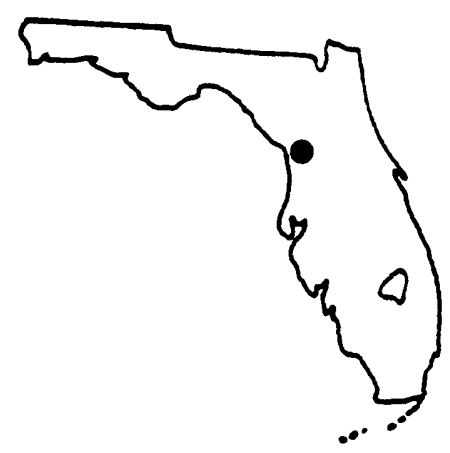

PROBLEM: Proposals are being considered by the management district to develop the water resources of the study area for water supply. Insufficient data exist to establish relationships between streamflow, tidal stage, and salinity distribution in the area. Such relationships are needed to determine streamflow requirements necessary to maintain healthy and productive estuaries.

OBJECIIVE: Determine salinity changes that may occur in selected estuaries if freshwater inflow is reduced by spring or aquifer pumpage.

APPROACH: Recording streamflow, tidal stage, and salinity stations will be installed on rivers and spring discharge streams. Field measurements will be made to define the location of isohaline lines as a function of salinity at a reference station. Regression analyses will be used to relate locations of the saltwater wedge to streamflow and tide stage. Model analyses will be applied to define potential changes in ground-water and spring flow as a result of ground-water withdrawals for water supply.

PROGRESS \& SIGNIFICANI RESUIIS: Streamflow rating curves were developed for Homosassa, Chassahowitzka, and Weeki Wachee Rivers. Salinity runs were made on Withlacoochee, Crystal, Homosassa, Chassahowitkza, and Weeki Wachee Rivers to define longitudinal salinity distributions. Preliminary equations for prediction of salinity interfaces for Weeki Wachee River were completed. Recording streamflow, tidal stage, and salinity stations were installed on Chassahowitkza River.

PLANS_FOR THIS_YEAR: Process hydrologic data for analyses. Collect bathymetric data on Withlacoochee, Crystal, Homosassa, Chassahowitzka, and Weeki Wachee Rivers. Remove data collection instruments from site. Prepare final project report. 
FL-414 IMPACT OF ALTERED FRESHWATER FLOW ON THE SALINITY

CHARACTERISTICS OF THE ANCIOTE RIVER ESTUARY, FLORIDA

DATE PROJECT BEGAN: October 1983

DATE PROJECT ENDS: September 1987

PRINCIPAL INVESTIGATOR: M. Fernandez, Jr., Tampa

COOPERATING AGENCY: Southwest Florida Water Management District

PROBLEM: Growing demands for freshwater supplies and proposals for diversion of streamflow for agricultural, industrial and municipal purposes has generated concern that estuarine and coastal biological resources may be adversely affected by significantly altered salinity distribution. Adequate data are not available to evaluate the effects of reduced streamflow on salinity distribution for the Anclote River estuary. Also, adequate background biological data do not exist on which to base estimates of expected impacts of salinity changes within the river.

OBJECIIVE: To collect and analyze data to define the impact of altered freshwater inflow on the salinity distributions of the Anclote River. To establish salinity distributions in the river as a function of freshwater inflow conditions and astronomical tides using regression analysis to relate streamflow to precipitation in the Anclote River Drainage Basin prior to and after the well fields in the basin began pumping.

APPROACH: Measurements will be made of streamflow, salinity, and tidal variation within the estuary. Data collected will be analyzed using regression analysis. The location of the $0.5,5,18,25$, and 30 parts per thousand salinity will be identified. Inflow, tidal stage and salinity relationships will be developed by applying multiple linear regression techniques to continuous time-series recordings. A relationship between precipitation and streamflow in the basin prior to and after the well fields began pumping will be attempted using regression analysis.

PROGRESS\&SIGNIFICANT_RESULTS: Two sites were established to collect continuous tide (stage) and specific conductance (salinity) data in the lower tidal reach of the estuary at the mouth and U.S. Alt. I9, respectively. A site was established near the upper limits of the tidal reach, Cedar Street, to obtain stage (discharge) and specific conductance (salinity) data. The data were collected and processed on a continuous basis. Preliminary findings indicate that the station at Cedar Street is tidally affected and, therefore, the discharge cannot be accurately measured at the site. The extent of the saltwater-freshwater interface ( 800 umhos) during the peak of the dry season in 1985 was found to be about 1.5 miles downstream from Cedar Street.

PLANS FOR THIS YEAR: Continue collecting stage and conductivity data through December 1985. Review and interpret the data and prepare a draft of the final report by September 1986. 
FL-415 ASSESSMENT OF HYDROGEOLOGIC CONDITIONS AND ALTERNATIVES FOR SAFEGUARDING WATER QUALITY IN SOUTHNEST

SARASOTA COUNIY, FLORIDA

DATE PROJECT BEGAN: October 1983

DATE PROJECT ENDS: September 1987

PRINCIPAL INVESTIGATOR: $\quad$ C. B. Hutchinson, Tampa

COOPERAIING AGENCY: Southwest Florida Water Management District

RROBLEM: An assessment needs to be made of hydrogeologic conditions and measures that might be employed to maintain or improve water quality in southwest Sarasota County. Problems to be addressed include determining aquifer parameters and water quality, describing the ground-water flow system, and constructing digital models of ground-water flow and solute transport. The models will be used to better understand historical and future changes in water levels and quality due to expanding pumpage for municipal supply, an ongoing program to identify and plug or repair improperly constructed wells, the movement and dispersion of liquid waste injected into the Floridan aquifer.

OBJECIIVE: (1) To determine aquifer hydraulic parameters and water quality; (2) To provide a description of the ground-water flow system including effects of pumping, injection and circulation between zones; and (3) To use digital models experimentally to understand the flow system and the transport of chemical constituents.

APPROACH: The hydrogeologic system will be conceptualized using available and field-collected data. This conceptual model will form the basis for digital models of ground-water flow and solute transport. The models will increase the understanding of ground-water movement and transport of a single water-quality constituent in the complex hydrogeologic system. They will be applied to simulate: (1) hydrogeologic conditions under various rates of municipal pumping; (2) changes in sulfate concentration that might occur once improperly constructed wells are plugged or repaired; and (3) movement and dispersion of injected brine from reverse-osmosis facilities.

PROGRESS \& SIGNIEICANI RESULIS: Nine Regional Observation Monitoring Well Program (ROMP) wells were sampled for water quality and then instrumented with water-level recorders. Maps were prepared that show water levels and water quality in 5 permeable zones. Pumping test results from ROMP well TR5-2 Suwannee were verified using a radial-flow model. The model simulated water-level changes in TR5-2 Tampa and TR5-2 Ocala wells above and below the pumped zone, respectively. Hydraulic conductivities and other aquifer characteristics derived from the model calibration will be used as input data for a general solute transport model: 
PLANS_FOR_THIS_YEAR: A general solute transport model with radial coordinates will be developed. The model will simulate potential effects of injecting up to $1 \mathrm{Mgal} / \mathrm{d}$ of treated sewage or reverse osmosis reject water into a deep saline aquifer. The model may also be modified to assess internal circulation in a well that taps several permeable zones. A report describing the study will be prepared. 
FL-416 EFFECTS OF HIGHNAY RUNOFF ON THE WATER QUALITY

OF WETLANDS AND GROUND WATER

DATE PROJECT BEGAN: October 1983

DATE PROJECI ENDS: September 1988

PRINCIPAL INVESTIGATOR: DOnna M. Schiffer, Orlando

COOPERATING AGENCY: Florida Department of Transportation

PROBLEM: The Florida Department of Transportation (FDOT) is legally responsible for attenuating peak discharges and treating stormwater originating on State and Federal highways, and on commercial areas attached to these highways. Stormwater is treated by using three different structures-detention ponds, swales, and French drains; and in a nonstructural manner through the use of natural wetlands. Several problems concerning the treatment of highway runoff are known to exist. First, it is unknown whether any sites exist in Florida where the local ground-water quality has been degraded by highway runoff. Second, although specific studies have been performed on the utilization of wetlands for improving water quality, none has documented the effects caused by Florida's highways. Third, a potential problem exists in that the wetlands may reach some equilibrium state with respect to bed-sediment accumulation, and a high recurrenceinterval event could flush out the bed sediments, thereby placing a shock loading on the receiving water.

OBJECIIVES: (1) To evaluate the quality of the ground water in the vicinity of FDOT structures used for treating highway runoff, and to quantify constituent loads entering and leaving wetlands used for handling highway stormwater. (2) To define spatially, any ground-water constituent plumes found, and to define spatially, and possibly seasonally, the constituent uptake by the vegetation and the distribution of constituent mass within the bed sediments. (3) To analyze, using inference techniques, statistical procedures, and deterministic modeling, the speciation, movement, and effect of selected constituents as they move through the soil and wetlands. (4) To estimate the general effects on the water resources, both ground water and wetlands, which might be felt at other locations throughout the state of Florida due to the presence of highway runoff.

APPROACH: At selected sites (detention ponds, swales, and French drains), several wells will be drilled to obtain water levels for defining the ground-water gradient, and to allow for ground-water sampling. If the water-quality analyses indicate significant concentrations of any constituent, additional wells will be drilled to define the location and extent of the constituent plume. Three wetlands will be chosen for study. Constituent loads entering and leaving the wetlands will be estimated using water quality and quantity data collected during storm events. The necessary data will be collected using portable, battery-powered samplers 
and standard stream-gaging procedures. Bed sediment samples will be collected and analyzed so that estimates of constituent loads with in the sediment can be made. These data will describe the rate of movement and fate of the constituents within the wetlands.

PROGRESS___SIGNIFICANI_RESULTS: A new wetland site was selected for sampling and instrumentation. Bottom sediments and water were sampled once at this site. The instrumentation for the site was installed. A new detention pond was selected for study. At this site, wells were drilled and sampled twice. This site was surveyed, and a rain gage and stage recorder were installed. A new swale site was selected for study. Sampling continued at the other locations under study (one swale, one wetlands, and one exfiltration site).

PLANS_EOR THIS YEAR: Continue sampling of existing sites. Drill wells and sample at new swale site. Work with equipment at wetlands location to obtain automatic sampling of stormwater runoff entering wetlands. Begin outlining two reports for the study. 
FL-419 MOBILITY AND STABILITY OF ORGANIC COMPOUNDS IN TREATED

WASTEWATER APPLIED BY SPRAY IRRIGATION TO FIELDS NEAR

TALLAHASSEE, FLORIDA

DATE PROJECT BEGAN: October 1983

DATE PROJECT ENDS: September 1986

PRINCIPAL INVESTIGATOR: John F. Elder, Tallahassee

COOPERAIING AGENCY: City of Tallahassee

RROBLEM: Effluent waters from secondary treatment of sewage are likely to contain hydrocarbons which may be converted to halogenated hydrocarbons by reaction with the chlorine used in the treatment process. Land application by spray irrigation may cause some transport of these substances to ground water. Spray irrigation is also accompanied by pesticide application, producing another possible source of ground-water contamination by organic compounds. This problem is poorly documented and has not been studied at all in the Tallahassee area, despite extensive inorganic monitoring of the spray fields in the area.

OBJECIIVES: The objectives of the investigation are: (1) to identify and determine concentrations of halogenated hydrocarbons and pesticides in waste-water used for spray irrigation at the Tallahassee spray fields; (2) to determine changes in concentrations and forms of organic compounds as the irrigation water moves into the ground-water system; and (3) to determine, in the unsaturated zone, the efficiency and mechanisms of removal of halogenated hydrocarbons and pesticides in irrigation water.

APPROACH: Stability of organic compounds in effluent during transport from treatment plant through the land application system will be determined by analysis of samples taken from the plant effluent, the holding pond area, and from ground water wells at the spray field.

PROGRESS_SIGNIEICANT RESULTS: Monthly data collection continued. Established data management system for entering data in WATSTORE through PRIME. Also obtained equipment for direct transfer of data from City laboratory to PRIME. Some data analysis conducted. New wells monitored for city's compliance with state regulations. Report from earlier phase of study approved and published as WRI 85-4006.

PLANS FOR THIS YEAR: Continue reconnaissance of organic and inorganic concentrations in irrigation water and ground water. Data analysis and preparation of report. 
RERORIS IN PROCESS:

Pruitt, J. B., Elder, J. F., and Relley, I. L., Wastewater application by spray irrigation on a field southeast of Tallahassee, Florida: Effects on groundwater quality, 1983-85.

REPORTS RETEASED:

Yurewicz, M. C., 1983, Hydrologic data from an area southwest of Tallahassee, Florida where municipal wastewater effluent is applied by spray irrigation: U. S. Geological Survey Open-File Report 83-769.

Elder, J. F., Hunn, J. D., and Calhoun, C.W., 1985, Wastewater application by spray irrigation on a field southeast of Tallahassee, Florida: Effects on ground-water quality and quantity, 1980-82: U.S. Geological Survey Water-Resources Investigations Report 85-4006, 41 p.

Yurewicz, M. C., and Rosenau, J. C., 1986, Effects on ground water of spray irrigation using treated municipal sewage southwest of Tallahassee, Florida: U. S. Geological Survey Water-Resources Investigations Report 86-4109 [in press]. 
FL-422 IMPACIS OF SELECTED DEVEIOPMENTAL ACTIVITIES ON

THE QUALITY OF WATER IN THE FLORIDAN AQUIFER SYSTEM, CENIRAL FLORIDA

DATE PROJECT BEGAN: ApriI 1984

DATE PROJECT ENDS: September 1987

PRINCIPAL INVESTIGATIOR: Albert T. Rutledge, Orlando

COOPERATING AGENCY: Federal Program

PROBLEM: There is a need to appraise the quality of ground water in relation to major developmental activities prevalent in recharge areas of the Floridan aquifer system. Many studies have dealt with ground-water quality, although most have not emphasized organic chemicals or trace metals. The three developmental activities of concern are: (1) use of drainage wells for stormwater disposal in urban areas, (2) use of pesticides and fertilizers in citrus groves, and (3) use of various chemicals in processing of phosphate ore and use of interconnector wells for drainage in phosphate mining areas.

QBJECTIVES: (1) To define ambient ground-water chemistry in selected recharge areas of central Florida under stress of urbanization, agriculture, and mining with emphasis on organic chemicals and trace metals, (2) to extrapolate conclusions reached to the entire aquifer system and other aquifers as applicable and (3) to develop sampling networks useful for long-term trend analysis.

APPROACH: (1) Research chemicals in use and sample "worst-case" water for the purpose of GS-MS scanning for other contaminants present, (2) determine which chemicals are known to be contaminating ground water in each area so that further analysis may be as specific as possible, (3) establish water-level recorders at a few sites and measure water levels periodically at many sites, (4) inventory new wells for sampling and install new wells where needed, (5) describe physics of flow systems using flow net analysis or digital modeling, (6) conduct thorough sampling of wells in each area, (7) describe the movement of contaminants in the ground-water systems through the development of conceptual models.

RROGRESS_SIGNIFICANT_RESULIS: Sampling of source-waters (worst-case conditions) in the 3 areas of development was completed. First phase of sampling water in receiving aquifers in each area was also completed. It is hypothesized that the prevalent contaminants are: (1) volatile organics in the urban area; (2) pesticides in the citrus area; and, (3) trace elements in the mining area. Report on preliminary progress has been written and given subdistrict and district review.

PLANS FOR THIS YEAR: Initiate 2nd phase (detailed) part of investigation. This will include rigorous sampling of water in receiving aquifers and some sampling of waters and sediment at specific points of entry to develop understanding of mechanisms. 
(FL-422)

RERORIS IN PROCESS:

Rutledge, A. T., Impacts of 3 land uses on GW quality in central Floridapreliminary results. 
FL-424 QUANTITY AND QUALITY OF WATER APPLIED TO IRRIGATED CROPS

OF SELECTED SITES IN THE EAST GIADES AGRICULTURAL

AREA, SOUTH DADE COUNIY, FLORIDA

DATE RROJECT_BEGAN: February 1984

DATE PROJECT ENDS: September 1986

PRINCIPAL INVESTIGATOR: Bradley G. Waller, Miami

COOPERATING AGENCY: South Dade Soil and Water Conservation District

PROBLEM: The East Glades Agricultural area in south Dade County, Florida covers about 10,000 acres and is used for growing truck crops in the winter. The area is low lying, 4 to 5 feet above NGVD, and the soil type is a poorly drained marl. The land has been in agricultural use for over 60 years but has only recently received development pressure from the rapidly expanding urban areas near Miami. The water levels in the area are highly controlled, and canals provide both flood control and a means to recharge the aquifer. The use and quality of water in this area is of concern because of increased needs in the agricultural and urban areas during the winter dry season. The amount of water used in this agricultural area is currently unknown, and the effect of agricultural chemicals on the canal system and sole-source Biscayne aquifer is only slightly known.

OBJECTIVE: To determine the effect that different agricultural management practices and irrigation have on surface-water and ground-water quality, and ground-water levels in the East Glades Agricultural area in south Dade county. Water levels are regulated to protect agricultural areas from flooding and eventual crop loss, and to prevent the consequences of saltwater intrusion. Crops are irrigated using overhead sprinkler systems but are unregulated as to the amount of water used. Overhead sprinklers are also used to alleviate crop damage from freezing conditions.

APPROACH: Two study plots have been selected in the East Glades area which represent characteristic agricultural use. One site has a recently constructed, extensive drainage-ditch network, and runoff from this field to a canal is via pumping. The other site is about the same size but does not have the extensive drainage network; runoff from this field to the canal is by gravity discharge through culverts. With in each study plot, observation stations will be established to measure water levels on a periodic and continuous basis and rainfall amounts. During periods of discharge from the fields, as a result of drainage or rainfall, the rate of flow moving from the fields and into the canal will be measured. The irrigation pumps will be rated, and the effects on the water levels in the area will be measured. water-quality samples will be taken from both surface-water and ground-water stations. Surface-water samples will be taken at the same point and concurrent with the discharge stations. Ground-water samples will be taken upgradient and downgradient of the agricultural fields. Two wells will be at each location-one shallow (10 to 15 feet) and one deep (50 to 60 feet, above the salt front). 
PROGRESS \& SIGNIFICANI RESULIS: Eight continuous water level recorders have been installed in the two test plots. Thirty-three periodic water level measurement stations have also been installed to supplement the continuous data under test conditions. Two geologic test wells and five ground-water quality wells have been installed to monitor movement and concentration of agricultural chemicals. All stations have been set to MSL. Precipitation is recorded at three stations.

PLANS FOR THIS YEAR: Complete rough draft of report. 
FL-425 RECONNAISSANCE OF WATER QUALITY AT A DEPARTMENT OF ENERGY SITE, PINELLIAS COUNIY, FLORIDA

DATE PROJECT BEGAN： January 1985

DATE PROJECT ENDS: September 1986

RRINCIPAL INVESTIGATOR: Mario Fernandez, Jr., Tampa

COOPERATING AGENCY: U. S. Department of Energy

PROBLEM: In April 1984, the Department of Energy commissioned the U.S. Geological Survey to perform an initial or phase I water water-quality study at the U.S. Department of Energy's Pinellas Plant. The result of the study was a report titled "Reconnaissance of water quality at a U.S. Department of Energy site, Pinellas County, Florida" by Mario Fernandez, Jr. (WRIR 854062). The study included 1) a literature search, 2) an electromagnetic survey, 3) the drilling of 4 test holes and installation of monitoring wells, 4) collection and physical analysis of cores from a test hole, 5) collection of water samples from the monitor wells and two ponds, and collection of bottom material from the ponds for inorganic and organic constituent analyses. As a result of the reconnaissance study, seven areas were found to need further evaluation.

OBJECIIVES: The objective of this study, phase II, is to evaluate the plant site for water quality and hydrogeological properties and monitor the site for possible changes that could occur due to plant operation. The study will, 1) determine the rate of ground-water migration at the plant site, 2) identify the direction of ground-water movement, 3) monitor ground and surface water at the plant site for select chemical constituents, and 4) sample bottom material from the ponds and identify indicator constituents in order to monitor migration of contaminants from the ponds. The study will monitor the quality of ground water moving from beneath the building site. In addition, the Geological Survey will be available for technical assistance as the need may occur.

APPROACH: The following tasks will be accomplished to meet the objectives of the study.

1. 4.5 acre tract--An electromagnetic device along with a flux magnetometer will be used to determine whether any metal drums are buried in a 4.5 acre tract that is part of the site.

2. An electromagnetic device will be used to survey the ground conductivity in a 36-acre undeveloped area of the plant site. A 50foot grid will be used. The survey will complete the investigation for buried metallic debris and containers in the site.

3. The ground and surface water quality of the undeveloped area of the plant site will be sampled and analyzed semi-annually for nutrients major constituents, total organic carbon, manganese, and zinc. 
4. Ponds and ground-water quality--An investigation will be made to determine whether organic compounds and trace elements are leaching and migrating from the east and west ponds in the undeveloped area of the plant site.

5. A water-table contour map will be prepared of the plant site and adjacent area. The map will be used to determine the direction of groundwater movement.

6. Aquifer test--An aquifer test of the surficial aquifer, using the recovery method, will be performed on two 4-inch diameter wells screened over the entire thickness of the aquifer to determine the hydraulic conductivity. The hydraulic conductivity, along with the hydraulic gradient and porosity, will be used to estimate the rate of ground-water movement in the area of the plant site.

7. Surface water, groundwater beneath stormwater detention basins, and sediments will be sampled semiannually and analyzed for inorganic and organic constituents.

8. Shallow aquifer monitor wells will be installed near the building in order to collect water samples for analysis of inorganic and organic constituents that may originate from leakage within the building.

PROGRESS_\&_SIGNIEICANT_RESULIS: The 4.5-acre site investigation was completed when buried drums were found at the site as a result of an electromagnetic and flux magnetometer survey of the site. The burial sites were delineated using the flux magnetometer and a soil coring device. An E.P.A. contractor has taken over the investigation. Two 4-inch diameter wells were installed and have been developed for an aquifer test. The ground conductivity survey, 50-foot grids, has been completed and the results are being evaluated.

PLANS FOR THIS YEAR: Complete the planned investigation and prepare report on findings.

REPORIS REILASED:

Fernandez, Mario, Jr., 1985, Reconnaissance of water quality at a U.S. Department of Energy site, Pinellas County, Florida: U. S. Geological Survey Water-Resources Investigations Report 85-4062. 
FL-427 POLLUTION POTENTIAL OF THE FLORIDAN AQUIFER SYSTEM FROM SINKHOLES AND INTERNALLY DRAINED AREAS IN WEST-CENIRAL FLORIDA

DATE RROJECT BEGAN: October 1984

DATE PROJECT ENDS: September 1986

PRINCIPAL INVESTIGATOR: J. Trommer, Tampa

COOPERAIING AGENCY: Southwest Florida Water Management District

PROBLEM: The potential for pollution of the Floridan aquifer system from sinkholes and internally drained areas exists through most of west-central Florida. Limestone crops out in parts of the area and is known for conducting surface water and effluent through open conduits into the limestone before natural purification, absorption, and filtration through soils and sand can occur. Internally drained areas may present a greater threat to the fresh ground-water supply than isolated sinkholes because of their larger drainage areas. Much concern has been expressed about the quantity and quality of water being discharged to the aquifer.

OBJECIIVE: To locate and define point sources of ground-water pollution through sinkholes and internally drained areas; estimate volume of surfacewater storage, recharge rates, and drainage areas of selected sinkholes; identify land use; and determine quality of stormwater runoff into selected sinkholes.

APPROACH: A literature review and an inventory of sinkholes and internally drained areas using aerial imagery, maps, and field reconnaissance will be conducted. Sinkholes and closed drainage areas will be classified on the basis of their potential to pollute the Floridan aquifer system. Hydrologic data at selected sites will include preparation of maps showing (1) thickness of the overburden, (2) confining layers, (3) head differences between the Floridan aquifer system and the surficial aquifer, (4) waterquality data, and (5) contour maps of aquifers showing general directions and rates of ground-water movements at sink sites and adjacent areas.

PROGRESS \& SIGNIFICANT RESULTE: A literature search was conducted to find all reports concerning sinkholes, internally drained basins, and pollution potential. This was followed by an inventory of sinkholes and internally drained basins using topographic maps, aerial photos, and field reconnaissance. Six sites were selected from this inventory to conduct more detailed studies. These sites are the Bear-Sink complex, Curiosity Sink, the sink in north Crews Lake, Peck Sink, Blue Sink, and the internally drained basin of Brandon. Groundwater levels, stage, and streamflow measurements were made periodically at each site where appropriate. In addition, nineteen sets of water-quality samples were collected for analysis 
by USGS labs. The state of Florida epidemiology research center was contracted to collect and analyze fourteen samples for viral content. Maps of the overburden, topography, land use, and location of the study sites were prepared. A contour map showing the general direction of the groundwater flow in the study area was also prepared. The first draft of the report was started.

PLANS FOR IHIS YEAR: Evaluate water-quality data as they become available from the Central Labs. Map the confining layers and ground-water movement, and describe the hydrology at the selected sites. Prepare illustrations and write the final report. 
FL-428 SURFACE GROUND WATER RELATIONSHIPS IN NORIHWEST

HILLSBOROUGH, NORIHEAST PINELIAS, AND SOUTH PASCO COUNIIES

DATE PROJECT BEGAN: October 1984

DATE PROJECT ENDS: September 1987

RRINCIPAL INVESTIGATOR: Miguel A. LOpez, Tampa

COOPERAIING AGENCY: Southwest Florida Water Management District and Pinellas County

PROBLEM: Well-field pumpage from the Floridan aquifer system that underlies the rapidly developing study area has been blamed by residents for contributing to excessive, long-term lowering of water levels in lakes and the surficial aquifer. A need exists to define the degree of interaction between water levels in lakes, the surficial aquifer, and the Floridan aquifer system so that regulatory decisions can be based on a realistic understanding of the hydrologic system and how the system may react to pumpage and locations of pumpage centers.

OBJECIIVE: (1) To determine the relationship between water levels of selected lakes and ground-water levels in the surficial aquifer and the Floridan aquifer system, (2) To develop methods for evaluating the effects of well-field development on the levels of lakes and the surficial aquifer, and (3) To determine the effects of well-field pumping on lake levels.

APPROACH : This study will evaluate the effects of ground-water withdrawals on lake levels by use of stochastic and deterministic models. Multiple regression is the primary tool that will be used in the investigation to take advantage of the availability of extensive lake-level and pumpage data in the area. Levels of individual lakes, the dependent variable, will be regressed to help define lakes that are significantly related to groundwater withdrawals from the well-fields. Independent variables of pumpage, water levels in the Floridan aquifer system and surficial aquifer, and some measure of recharge by use of rainfall and estimated evapotransporation will be used.

PROGRESS_\&_SIGNIFICANI RESUITS: A database for the study was compiled and stored on-line on the Subdistrict PRIME system. The database includes the following from the beginning of record through September 1983: (1) monthly average stage of 21 lakes; (2) monthly average water level of 25 observation wells; (3) monthly rainfall at 3 rain gages; (4) monthly evaporation of 2 evaporation pan stations; and, (5) monthly pumpage from East Lake, CosmeOdessa, Eldridge-Wilde, Section 21, and South Pasco well fields. 
Preliminary regression analysis has defined the relationship between the change in monthly average lake level of Lake Alice and monthly rainfall at Cosme-Odessa well field, monthly evaporation at Lake Padgett, and monthly average water level in St. Petersburg Cosme Well 3. The correlation coefficient was 0.85 and the standard error of estimate was 0.21 foot. In order to estimate evaporation for use in a predictive equation, the relation of monthly pan evaporation at Lake Padgett to monthly rainfall and the theoretical potential evaporation was defined by linear regression. The monthly evaporation regression had a correlation coefficient of 0.83 and a standard error of estimate of 0.61 inch.

PLANS FOR THIS YEAR: Extend the data base through September 1985 in order to include the most severe drought since 1956. Rerun the preliminary regressions to include this extreme condition. Complete the regression analysis on all the lakes and prepare the first draft of the report. 
FL-429 HYDROLOGY OF THE CITRUS PARK AREA,

HILISBOROUGH COUNIY, FLORIDA

DATE PROJECT BEGAN: October 1984

DATE PROJECT ENDS: September 1986

PRINCIPAL INVESTIGATOR: Miguel A. Corral, Jr., Tampa

COOPERATING AGENCY: Southwest Florida Water Management District

RROBLEM: Northwest Hillsborough County has a diversity of hydrologic problems. The area contains two municipal well fields that export water to coastal cities and many private wells. A third municipal well field is planned to supply an estimated 9 million gallons per day. Concurrent with urbanization and ground-water development are problems of flooding, sinkhole formation, declining lake levels, saltwater intrusion, pollution of aquifers and streams, and depletion of ground-water supplies. The results of this study will have transfer value to define hydrology of other karst areas experiencing urbanization.

OBJECIIVE: To compile, evaluate, and interpret hydrologic and geologic data available for the Citrus Park area and present the results in a map report. The study would aid county commissioners, consulting engineers, hydrologists and others in assessing development related to hydrologic problems.

APPROACH: A major element will be preparation of maps and figures that show the water table in the surficial aquifer and potentiometric surface of the Floridan aquifer system; chemical quality of surface and ground waters; thickness of surficial materials; top of limestone; major springs and sinkholes; flooding problems; potential sources of surface- and ground-water contamination, and the general direction of ground-water movement. The study will evaluate primarily existing data and utilize reports that include parts of the study area. Field work will be limited to collection of data to update and supplement existing data.

RROGRESS \& SIGNIFICANI RESUIIS: Draft of report has been completed, along with maps and figures that show the water table in the surficial aquifer and potentiometric surface of the Floridan aquifer system, chemical quality of surface and ground waters, thickness of surficial materials, top of limestone, major springs and sinkholes, flooding problems, potential sources of surface- and ground-water contamination, and the general direction of ground-water movement. The report primarily evaluates existing data and utilized reports that include parts of the study area. Field work was limited to collection of data that supplemented existing data.

RLANS FOR_THIS YEAR: Complete final report, submit for review, approval, and publication. 
DATE PROJECT BEGAN: October 1984

DATE PROJECT ENDS: September 1988

PRINCIPAL INNESTIGATIOR: G. L. Barr, Tampa

COOPERATING AGENCIES: Southwest Florida Water Management District and Polk County

PROBLEM: Polk County in central Florida has a diversity of water-quality problens that are apparently related to geologic structure. The principal aquifer (Floridan Aquifer System) consist of carbonate rocks that have actively-developing sinkholes. Localized incidents of ground-water degradation emphasize the vulnerability of the aquifer system to natural hazards and to man's activities. The need exists for a comprehensive study that will provide water managers and environmentalists with an effective program for understanding water-quality problems.

OBJECTIVE: Access water-quality problems both site specific and areally. Define areas that are susceptible to water-quality degradation. Define surface lineations utilizing aerial photos. Document and map known sinkholes. Delineate framework; and prepare Phase II proposal for intensive hydrologic and water-quality evaluation.

APPROACH: The reconnaissance phase would involve compilation of existing water-quality data and reported incidents of ground-water contamination. Aerial and satellite photographs will be evaluated as reconnaissance tools for defining surface lineations. Defined lineations will be related to water-quality problems or as areas of potential water-quality degradation. Available geophysical logs of test wells will be used to define cavities in the limestone. Surface geophysics will be applied to enhance the understanding of suspected geologic anomalies. Closed depressions will be defined and related to potential sources of contamination. Data on definition of the hydrogeologic framework will be extracted largely from published reports and updated based on readily available data.

RROGRESS_SIGNIFICANT_RESULTS: A planning document was prepared for defining geologic controls on ground-water movement and contamination and for defining areas of Polk County that are susceptible to water-quality degradation. Literature research was conducted; existing water-quality data were collected and evaluated; occurrences of ground-water contamination related to geologic conditions were evaluated, karst features and closed depressions were delineated by use of topographic maps, aerial photos and satellite imagery; research to define hydrogeologic setting was accomplished. A network for sampling was proposed.

PLANS FOR THIS YEAR: A network of about 50 ground-water sites will be developed for collecting water from suspected areas of potential ground-water contamination. Water samples will be analyzed for major ions, trace metals, field measurements, coliforms, organics and radio chemicals. Preparation of a report that describes the hydrogeology and results of sampling will be completed. 
FL-431 SURFACE WATER HYDROLOGY OF THE FLORAL CITY POOL OF TSALA APOPKA IAKE, WEST-CENIRAL FLORIDA

DATE PROJECT BEGAN: October 1984

DATE PROJECT ENDS: September 1987

PRINCIPAL INMESTIGATOR: L. A. Bradner, Orlando

COOPERATING AGENCY: Southwest Florida Water Management District

PROBLEM: Tsala-Apoka Lake can be divided into three parts--the Floral City Pool, Inverness Pool, and Hernando Pool. The Floral City Pool behaves hydraulically differently from the others, although it is the most upstream and overflows into the others at high water. During the drought of 1981, much of the Floral City Pool was dry, while the others retained significant amounts of open water.

QBJECIIVE: (I) To document water levels of surface-water and ground-water sites, estimate direction and quantity of flow at selected locations in the Floral City Pool, and to determine what extent the fluctuations of the surface-water elevations can be explained in terms of surface-water hydrology.

APPROACH: Surface-water gaging station and flow meters will be used to determine flow into and out of the lake. Water-level recorders will be placed on upper Floridan aquifer wells for collection of simultaneous data of water-level fluctuations. A water-quality input/output analysis will be performed.

PROGRESS \& SIGNIFICANI RESULIS: The lake experienced both a drought period and flood period during the year. Several surface-water trips were completed to measure inflow and outflow to lake. Wet season and dry season ground-water potentiometric maps were drawn. Water-quality measurements were made during drought period.

PLANS FOR THIS YEAR: Continue field work, data analysis and report writing. By end of year, data collection will be completed and first draft of report nearly completed. 
FL-432 EFFECIS ON GROUND-WATER QUALITY FROM THE APPLICATION

OF DOMESTIC WASTEWATER-TREATMENT SLUDGE TO SOILS OVER-

LYING THE BISCAYNE AQUIFER, DADE COUNIY, FLORIDA

DATE PROJECI BEGAN： October 1984

DATE PROJECT ENDS: September 1988

RRINCIPAL INVESTIGATOR: Barbara Howie, Miami

COOPERATING AGENCIES: South Dade Soil and Water Conservation District, and Florida Department of Environmental Regulation

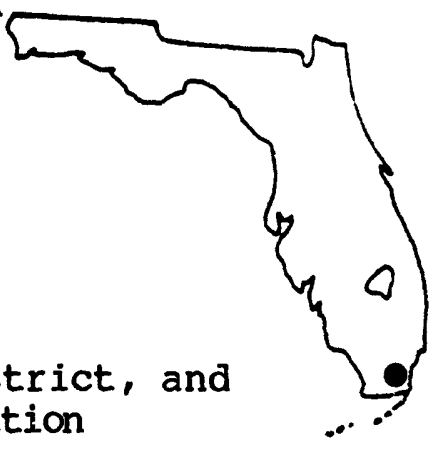

PROBLEM: Because nutrients used in agriculture are rapidly lost by leaching from south Dade's Rockdale soils and by runoff from marl soils, growers want to use domestic wastewater treatment sludges as a soil conditioner and organic nitrogen source. There is a growing concern about what effect sludge application may have on ground-water quality in the Biscayne aquifer.

OBJECIIVE: To determine the effects of sludge application on ground-water quality, to compare the effects of sludge application with the effects of current practices of using fertilizers and soil conditioners and to develop a conceptual model explaining the fate of sludge constituents and the variations in effects on water quality.

APPROACH: Study elements will include determinations of the chemical coptaminants present in ground-water and soil before and after sludge application to test plots comprised of south Dade's two soil types and two crop types. The migration of sludge contaminants will be investigated by determining the lithologic units where contaminants are most likely to move and by monitoring water levels in the vicinity of test plots. Records of rainfall, irrigation, fertilizers and sludge application at each plot will be maintained.

PROGRESS \& SIGNIFICANI RESULIS: Five test plots were chosen and implemented upgradient and downgradient with well clusters, water-level recorders and rainfall recorders. Eighteen additional water-table wells were installed for monitoring ambient ground-water quality. Selected wells were sampled in March and August for nutrients, metals, pesticides, and organic priority pollutants.

PLANS EOR THIS YEAR: Sludge will be applied to the test field at the beginning of the growing season. Ground water beneath the fields will be sampled under varying hydrologic conditions. Rainfall and water-level data will be collected at the test fields. Report interpretating the first year's data will be prepared. 
FL-433 EFFECIS OF STORMWATER CONTAMINANTS FROM EXFILTRATION TRENCHES ON THE BISCAYNE AQUIFER, DADE COUNIY, FLORIDA

\section{DATE PROJECT BEGAN: October 1984}

DATE PROJECI ENDS: September 1987

RRINCIPAL INVESTIGATOR: Donald J. MCKenzie, Miami

COOPERAIING AGENCY: South Florida Water Management District

RROBLEM: Exfiltration trenches are a commonly used method of excess stormwater runoff disposal in Dade County, Florida. The trenches extend into the water table of the sole-source Biscayne aquifer, and some are designed to overflow into adjacent surface-water bodies. Concern has been raised by regulatory agencies as to the effect of direct infiltration of stormwater contaminants on ground-water quality. Runoff from roadways, parking lots, and industrial areas is the primary concern.

OBJECTIVE: (1) Determine the effects of exfiltration trenches for stormwater disposal on the quality of receiving waters; (2) Determine if exfiltration trenches, as is presently thought, are an effective method of removing contaminants from stormwater runoff before reaching the groundwater system or receiving surface-water bodies; and (3) Determines if exfiltration trenches are as effective at removing contaminants as vegetated swales, the alternative stormwater disposal method in Dade County.

APPROACH: The sampling sites in two different lithologies will be selected which represent currently permitted exfiltration trenches. They will be instrumented with two continuous water-level recorders and a rain gage. Six wells for ground-water quality sampling will be installed below and adjacent to the trenches. Water-quality samples will be collected for 10 storm events with various antecedent dry conditions and analyzed for nutrients, trace metals physical parameters, and trace synthetic organic compounds.

PROGRESS \& SIGNIFICANI RESUIIS: Two study sites were selected, each typical of the two predominant lithologies in southeast Florida. Ground-water level recorders were installed and wells for water quality analyses were drilled. Two samplings for chemical analyses were made at both sites, qualified by antecedent weather conditions.

PLANS FOR THIS YEAR: Sample each site 6-8 more times for water quality analysis and evaluate data. Sampling schedule will be dependent on antecedent weather conditions. 
FL-434 THE EFFECIS OF WEIL PLUGGING ON GROUND-WATER QUALITY IN THE FORT MYERS, FLORIDA, AREA

DATE PROJECT BEGAN: October 1984

DATE PROJECT FNDS: September 1986

PRINCIPAL INVESTIGATIOR: Henry R. LaRose, Fort Myers

COOPERATING AGENCY: South Florida Water Management District

PROBLEM: Before 1968, nearly all water wells were constructed with galvanized or black iron pipe. Because of casing decay and short cased wells, many deep artesian wells are sources of saline-water intrusion into overlying freshwater-bearing aquifers. An energetic well plugging program has been undertaken to correct this upward intrusion. Now a study on the effects of plugging on the quality-of-water of the freshwater systens is needed before the plugging program is expanded.

OBJECTIVE: In the past few years more than 50 deep short cased artesian wells have been plugged in the study area. This study will assist in evaluating that plugging program and help in locating sites where other wells need to be plugged.

APPROACH: Sample between 1-500 wells, mostly privately owned, for specific conductance and chloride concentration. Compare current data with pre 1970's data in an effort to evaluate saline-water intrusion in the freshwater-bearing aquifers. Analyze maps of past and present water levels and maps showing past and present chloride concentrations to determine if the plugging is achieving its goals.

PROGRESS \& SIGNIFICANT RESULIS: Work is on schedule. Most of current field data collected. Compilation of the data and evaluation are in progress. Base maps drafted and potentiometric and chloride maps of current and historical data started.

PLANS_EOR THIS_YEAR: Finish data collection, interpretation, and write report. 
FL-436 QUALITY OF GROUND WATER IN THE FLORIDAN AQUIFER SYSTEM

AS RELATED TO SELECTED LAND USE, CENIRAL FLORIDA

DATE PROJECT BEGAN： October 1984

DATE PROJECI ENDS: September 1986

PRINCIPAL INVESTIGATOR: Albert T. Rutledge, Orlando

COOPERATIMG AGENCY: Florida Department of Environmental Regulation

PROBLEM: There is a need to appraise the quality of ground water in relation to major developmental activities prevalent in recharge areas of the Floridan aquifer system. Many studies have dealt with ground-water quality, although most have not emphasized organic chemicals or trace metals. The three developmental activities of concern are: (1) use of drainage wells for stormwater disposal in urban areas, 2) use of pesticides and fertilizers in citrus groves, and 3) use of various chemicals in processing of phosphate ore and use of interconnector wells for drainage in phosphate mining areas.

OBJECTIVES: 1) To define ambient ground-water chemistry in selected recharge areas of central Florida under stress of urbanization, agriculture, and mining with emphasis on organic chemicals and trace metals, 2) to extrapolate conclusions reached to the entire aquifer system and other aquifers as applicable, and 3) to develop sampling networks useful for longterm trend analysis.

APPROACH: (1) Research chemicals in use and sample "worst-case" water for the purpose of GC-MS scanning for other contaminants present, 2) determine which chemicals are known to be contaminating ground water in each area so that further analysis may be as specific as possible, 3) establish waterlevel recorders at a few sites and measure water levels periodically at many sites, 4) inventory new wells for sampling and install new wells where needed, 5) describe physics of flow systems using flow net analysis or digital modeling, 6) conduct thorough sampling of wells in each area, 7) describe the movement of contaminants in the ground-water systens through the development of conceptual models.

PROGRESS \& SIGNIEICANI RESULIS: Sampling of source waters to drainage wells was completed. This included surface inflow and stagnant water at the top of the water column in drainage wells. Sampling of water representing prevailing conditions in the Upper Floridan was begun. (10 wells sampled.) Volatile organics are apparently the prevailing contaminants.

PLANS FOR THIS YEAR: Rigorous sampling of wells representing prevailing conditions will be continued. Detailed sampling of test wells near an actively "taking" drainage well will be taken to increase understanding of reaction mechanisms. 
FL-438 TIDE-INDUCED CIRCULATION AND FLUSHING USING

TIDE GATES IN RESIDENTIAL CANAIS AT

CAPE CORAL, FLORIDA

DATE PROJECT BEGAN: June 1985

DATE PROJECT ENDS: September 1987

PRINCIPAL INVESTIGATIOR: Carl R. Goodwin, Tampa

COOPERATING AGENCY: Florida Department of Environmental Regulation

PROBLEM: Complaints about environmental quality of man-made finger canals abound in Florida and other coastal states. Poor water-quality conditions and public health hazards have been documented. The rapidly growing city of Cape Coral, Florida, has more than 400 miles of residential canals, 130 miles of which are tidally influenced. With a potential population of about 400,000 residents, water-quality degradation and eutrophication of the canals is expected to be rapid. The results could be both reduced viability of the canal system as a beneficial water resource and a reduced quality of life for Cape coral residents and visitors.

OBJECIIVE: (1) Combine existing field and computer techniques to develop methodology for predicting the degree of increased water circulation and constituent flushing that can be induced within the coastal canal system by various combinations of canal interconnections, tide-gate installations, and additional openings to tidal water; (2) Determine circulation and flushing increases that could be expected in a section of the Cape Coral system if same of these physical changes were implemented, and (3) Estimate the overall water-quality benefit to the canal system resulting from increased circulation and flushing.

APPROACH: (1) Develop, calibrate, and verify computer simulation models of water flow and conservative constituent transport in a suitable section of the Cape Coral canal system. The Branch flow model and Lagrangian transport model will be used. Data collection for model validation will include tides, bathymetry, discharge and dye dispersion; (2) Use validated models to test a series of alternatives (involving canal interconnections, tide gates, and additional tidal openings) for inducing greater circulation and flushing by more efficient use of available tidal energy; (3) Estimate probable change in dissolved oxygen (DO) by using model results, measured water colum concentrations, and sediment oxygen demand rates.

PROGRESS \& SIGNIFICANI_RESUITS: A network of 13 temporary tide gages was established and operated for about a month. Significant differences in tidal amplitudes and phase were found between different parts of the Cape Coral canal system. Based on these data, a permanent gage network of 9 stations was designed. 
Two preliminary flow models were developed to assess the potential that canal interconnection and tide-gate construction may have to improve water circulation and constituent flushing. The models were based on measured tide data and available physical data. The more realistically schematized model indicated that an average flow of 95 cfs could be induced at one site by simply connecting two adjacent dead-end canals. A tide-gate installed at the same site would increase the tide-induced, average-daily flow to $288 \mathrm{cfs}$. At this rate, the total volume of water moved through the canal system would equal the mean-tide volume of the system in about 3 days. These preliminary results indicate good potential to induce significant circulation by canal interconnection and use of tide gates.

PIANS FOR THIS YEAR: A fathometer survey of part of the canal system will be made to determine 1) areas of possible flow constriction, and 2) the range and distribution of water depth. Nine permanent tide gages will be constructed and temporary gages will be removed. Cross sections of the canals will be measured. Discharge, water-quality, and dispersion will be measured at selected sites. Hydrodynamic and constituent transport modeling will continue. Sediment oxygen demand will be measured. 
FL-439 NUMERICAL SIMULATION OF THE MIGRATION OF LANDFILL

LEACHATE IN A HIGHLY PERMEABLE SURFICIAL AQUIFER,

PALM BEACH COUNIY, FLORIDA

DATE PRQJECT BEGAN: June 1985

DATE PROJECT ENDS: September 1987

PRINCIPAL INVESTIGATOR: GarY M. Russell, Stuart

COOPERAIING AGENCY: Palm Beach County Solid Waste Authority

PROBLEM: Landfills are one of the principal sources of contamination threatening the highly permeable surficial aquifer system of coastal Palm Beach County. Most of the studies of landfills have been based solely on water-quality sampling and generally have descriptive objectives only, and do not attempt to fully define the hydraulic controls on contaminate migration. Responsible agencies recognize the need to progress beyond merely descriptive studies of leachate migration to analytical approaches that describe the physical and chemical processes that govern leachate movement. Needed are deterministic models of the hydraulic regime and transport processes taking place at a landfill.

OBJECIIVES: Describe the process of leachate migration from a landfill in an unconfined, partially-cemented carbonate aquifer using cross-sectional and/or three-dimensional computer models. Use computer models to validate the conceptual model of the migration process, to simulate the actual transport of leachate that has occurred, and to evaluate the likely future migration under long-term normal hydrologic conditions and under short-term high-stress conditions (severe storms). Extrapolate the results of the landfill simulation to other landfills in Palm Beach County as appropriate.

APPROACH: The data-collection effort and its time frame will be designed to answer the needs of the developing interpretative analysis of the landfill site. It will include an effort to improve estimates of hydraulic parameters and to obtain dispersivity parameters. The modeling analysis will include a hydraulic simulation of the site and the simulation of transport of conservative substances in the leachate. If linear hydraulic symmetry prevails along the axis of the leachate plume, a cross-sectional model design will be used for hydraulic analysis. Otherwise, the model will be three dimensional.

PROGRESS \& SIGNIFICANT RESUIIS: Geologic test well was drilled on the east side of the Lantana Landfill and detailed lithologic information collected. Twelve ground-water level monitor wells and one continuous water level recorder were installed and leveled. Surface resistivity and water quality data indicate a plume centered around 30 feet deep, approximately 1000 feet wide moving approximately 400 feet east of the landfill.

PLANS FOR THIS YEAR: Continue data collection and determination of hydraulic characteristics of the aquifer and continue development of a computer model. 
FL-442 EFFECTS OF SEPTIC TANRS AND DOMESTIC WETLS ON

WATER QUALITY AND LEVEIS, NORIHEAST

PALM BEACH COUNIY, FLORIDA

DATE PROJECT BEGAN： October 1985

DATE PROJECI ENDS: September 1988

PRINCIPAL INVESTIGATOR: Wesley L. Miller, Miami

COOPERATING AGENCY: Palm Beach County

RROBLEM: Rapid development of residential home sites serviced by septic tanks and private well is anticipated in northeast Palm Beach County. The area of about $250 \mathrm{~m}^{2}$ is presently undeveloped, but 15,000 to 20,000 homes may be built by the year 2000. Little existing data is available about the surficial aquifer system's water quality, hydraulic characteristics, or geology in the area. Near surface marls and frequent flooding may retard attenuation of septic tank effluent and allow contamination of the area's ground-water.

OBJECTIVES: (1) Determine the location, thickness, and extent of marls in the upper 50 feet of the aquifer; (2) locate aquifer zones containing high chloride concentrations; (3) determine pre-development ground-water quality; (4) determine attenuation of chemical, bacterial, and viral constituents in septic tank effluent in the hydrogeologic regime of the area; (5) provide ground-water level maps; and (6) provide predevelopment ground-water level and quality data bases.

APPROACH: (1) Conduct surface geophysical surveys to locate any portions of the area in which the aquifer contains residual sea water and to determine locations, thickness, and areal extent of marl units in the upper 50-feet of aquifer; (2) select sites, using geophysical data, and drill suites of background water-quality sampling wells to various depths in the aquifer; (3) select existing septic tank sites; (4) drill and sample monitor well to determine attenuation of septic tank effluent; and (5) establish ground-water level measurement network of wells to monitor water-table fluctuations as the area developes.

PLANS FOR THIS YEAR: Conduct geophysical survey, design and construct ground-water level and sampling well network, and begin water-quality sampling. 
FL-444 GEOHYDROLOGY OF THE SURFICIAL AQUIFER SYSTEM, VOLUSIA COUNIY, FLORIDA

DATE PROJECT BEGAN: October 1985

DATE PROJECT ENDS: September 1988

PRINCIPAL INVESTIGATOR: G. G. Phelps

COOPERATING AGENCY: Volusia County

PROBLEM: The uppermost aquifer in Volusia County is the surficial aquifer system. To date there has been no systematic study of lithology, flow system, rates of recharge and discharge, or water quality of the surficial aquifer system. Salty water occurs in the surficial aquifer from a combination of factors that include: (1) upward leakage from the Floridan system, (2) lateral or vertical encroachment due to ground-water pumping, and (3) lateral or vertical encroachment caused by ditching for surface drainage. As growth continues in Volusia County, the surficial aquifer is destined to play an increasingly important role in the management of the county's ground-water resource with regard to both water supply and solid and liquid waste disposal.

OBJECTIVES: The objectives of the proposed investigation are to: (1) Describe the lithology and thickness of the surficial aquifer system in Volusia County, (2) Map the thickness of the unsaturated zone, the water table, and the aquifer-flow system, (3) Describe the water-quality characteristics and hydraulic characteristics of the aquifer system, and (4) Quantify water use, and recharge and discharge rates for the surficial aquifer.

APPROACH: (1) Drill and sample approximately 100 shallow wells (less than 50 feet), (2) Drill 40-50 core holes through the surficial aquifer system, (3) Conduct 3-4 short-term aquifer tests to determine hydraul ic characteristics at selected sites (4) Map areas of potential upward leakage by comparing water table map with Floridan aquifer potentiometric maps, and (5) Install 6-8 water-level recorders at selected sites in order to estimate recharge amounts by summing incremental rises in the water table in response to rainfall.

PROGRESS \& SIGNIFICANI RESUIIS: New project.

PLANS FOR THIS YEAR: Drill several shallow wells and install 2-inchdiameter casings and screens. Sample shallow wells for water quality. Measure water levels periodically. Drill several core holes in aquifer for lithologic information. Install several water-level recorders. 
FL-445 ASSESSMENT OF WATER-QUALITY PROCESSES AFFECTING NUIRIENIS IN WEILANDS SIREAM

DATE PROJECT BEGAN: October 1985

DATE PROJECT ENDS: September 1990

PRINCIPAL INVESTIGATOR: Edward R. German, Orlando

COOPERATING_AGENCY: Reedy Creek Improvement District

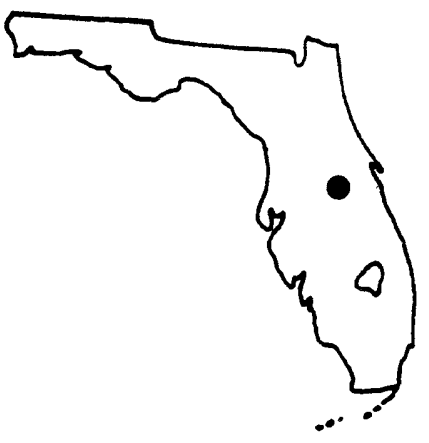

PROBIFM: Phosphorus concentrations in Reedy Creek are relatively high downstream from Walt Disney World treated sewage discharges. Dissolved oxygen concentrations are at times much lower than allowed by state regulations. The low DO may be due largely to natural runoff from swampy areas, or it may be related to nitrogen-conversion processes related to the wastewater effluent. Little is known about how Reedy Creek assimilates and cycles nutrients. A better understanding of the efficiency of wetlands streams in nutrient assimilation, and the effect of nutrient enrichment on such streams is required.

OBJECIIVES: Define the hydrologic environmental of the Reedy Creek wetlands system in terms of water storage capacity, mean depth, stage duration, and water residence time. Evaluate role of wetlands in nutrient cycling and DO variation. Determine loads and speciation of nitrogen and phosphorus at selected points in the basin. Measure the nutrient-retention capacity of the RCID wetlands, and the effect of the wetlands on downstream water quality.

APPROACH: The methods used to accomplish the objectives will require six different types of data collection. These are: sampling of soil cores and sediments from the wetlands; insitu experiments to measure sediment oxygen demand and mechanism of nutrient cycling; aerial and field surveys for determination of flooded area and water depth; operation of continuous DO monitors and streamflow stations; sampling of nutrients at selected load stations under a range of discharge conditions; and collection of samples along Reedy Creek to establish profiles of water quality.

PROGRESS \& SIGNIFICANT RESUIIS: New project.

PLANS FOR THIS YEAR: Review literature on nutrient cycling in wetlands. Begin collection of samples for load computation. Conduct logitudinal profile of $Q W$ along Reedy Creek during springtime low-flow conditions. Operate DO monitors along Reedy Creek. 
FL-446 WATER RESOURCES EVALUATION OF THE FRESHWATER

LENS ON KEY WEST, FLORIDA

DATE PROJECT BEGAN: October 1985

DATE PROJECT ENDS: September 1988

PRINCIPAL INNESTIGATOR: Donald J. MCKenzie, Miami

COOPERATING AGENCY: South Florida Water Management District

PROBLEM: A freshwater lens beneath the island of Key West is used by some residents as a potable water supply.., The lens and the saline water beneath it have also become a repository for stormwater and treated wastewater. The freshwater lens needs to be evaluated to determine the water-supply potential and the quality of the water.

OBJECIIVES: (1) Determine the areal extent and thickness of the freshwater lens on Key West, taking into account seasonal and tidal changes in the extent and thickness of the lens; (2) determine the areal variation in water quality of the freshwater lens.

APPROACH: A geophysical survey, if feasible, and wells drilled along transect lines will be used to describe the extent of the freshwater lens. Additional wells will be drilled to determine ambient groundwater quality and contaminants near the injection points of stormwater and wastewater. Tide gages and water level recorders will be used to determine the relation between tidal action and lens thickness.

PROGRESS \& SIGNIFICANI RESUIIS: New project.

PLANS FOR THIS YEAR: (1) Review existing hydrogeological literature, (2) use surface geophysical resistivity survey, where feasible, for aiding in determining well locations and describing the freshwater lens; (3) select well sites and secure drilling permits, (4) install wells, (5) measure chloride concentrations, temperature and specific conductivity with minimonitor, (6) install ground-water level recorders and tidal recorders, and (7) delineate areal and vertical extent of fresh-water lens. 
FL-447 SALINITY CHARACTERISTICS AND EFFECTS OF FRESHWATER WITHDRAWALS, MYAKRA RIVER, FLORIDA

DATE PROJECT BEGAN: October 1985

DATE PROJECT ENDS: September 1988

RRINCIPAL INVESTIGATOR: Rathleen M. Hammett, Tampa

COOPERATING AGENCY: Sarasota County

RBOBLEM: Demands for freshwater are increasing in coastal areas of southwest Florida. Coastal streams like the Myakka River may be used to augment present supplies. Withdrawal or diversion of freshwater from the stream may result in upstream encroachment of saltwater and elevated salinity levels in the estuarine reach of the stream. Changes in salinity may produce adverse biological changes. Salinity characteristics must be evaluated prior to withdrawal or diversion for water supply.

OBJECTIVES: Describe in detail the salinity characteristics of the Myakka River estuary for a wide range of freshwater inflow and tide conditions. Develop mathematical relations describing salinity as a function of freshwater inflow and astronomical tide. Evaluate water-supply potential of the Myakka River and evaluate alternative plans for water-supply withdrawal. Evaluate projected effects of withdrawal on the salinity distributions using the mathematical relations developed in objective 2 .

APPROACH: Tide and salinity will be monitored at three permanent and one temporary stations. Specific conductance will be measured as part of periodic field surveys for a wide range of freshwater inflow and tide conditions. Multiple linear regression analysis will be used to relate salinity to daily mean discharge for selected tidal stages. Low-flow frequency analysis of existing gaging-station records and draft-storage analysis of existing lakes and potential storage areas will be used to evaluate water-supply potential. Regression equations will be used to define the location of the salt front for possible withdrawals or diversions.

PROGRESS \& SIGNIFICANI RESULIS: New project.

RLANS_FOR_THIS YEAR: Install temporary salinity monitor. Conduct periodic surveys of specific conductance. Compile and check data from existing tide and salinity monitors. Begin regression analysis of salinity versus discharge for selected tidal stages. 
FL-448 PROCEDURE FOR ASSESSING WATER USE FROM THE SOLE SOURCE

BISCAYNE AQUIFER, SOUTHEAST FLORIDA, USING A

GIS (GEOGRAPHIC INFORMATION SYSTEM)

DATE PROJECT_BEGAN: October 1985

DATE PROJECI ENDS: September 1988

PRINCIPAL INVESTIGATIOR: Bradley G. Waller, Miami

COOPERATING AGENCIES: Florida Department of Environmental Regulation and South Florida Water Management District

PROBIEM: Water use in Southeast Florida has increased greatly over the past few years: Presently, more than 90 percent of the nearly 1 billion gallon per day of water used on the southeast coast come from ground-water sources. Although the data reported are the best available there are many unknowns in certain water-use categories, and no management tools are now available to predict trends in water use. In order to report quantitative water use information, a comprehensive, systematic water-use investigation is necessary for southeast Florida, using the latest in analytical tools to determine water use and predict trends.

OBJECIIVES: To determine quantitative water use data for the sole-source Biscayne Aquifer in Southeast Florida using a state-of-the-art geographic information and data base management system.

APPROACH: Develop and implement a strategy for collection of water use information for regulated and nonregulated users. Assimilate existing water use data and enter it into State Water Use Data System. Develop methods to measure nonregulated users. Determine confidence levels and validity of calculated water use by land use category. Use the GIS data base management system as a prediction tool for determining water use for various scenarios. Develop a program to verify the reported data and data estimated.

PROGRESS \& SIGNIFICANI RESUITS: New Project.

PIAANS EOR THIS YEAR: Begin entering land use and water use information into GIS ARC/INFO system. Set up data base management system. Contact utilities for water use and withdrawal information. Begin field measurements of agricultural water use in Dade County. 
DATE PROJECT BEGAN： January, 1986

DATE PROJECT ENDS: September, 1988

RRINCIPAL INVESTIGATIOR: Michael L. Merritt, Miami

COOPERAIING AGENCY: Metro-Dade Environmental Resources Management

PROBLEM: Water supply in highly populated southeastern peninsular Florida is obtained almost entirely from the surficial aquifer. The presence of a chloride plume in the aquifer was established in 1979 and traced to a flowing well in Chekika Hammock State Park that was constructed in 1944. It was plugged in March 1985. Dade County plans to develop a new wellfield to the northeast of the plume, and concerns exist about possible wellfield contamination and about the future movement and rate of dilution of the plume.

OBJECIIVES: The objectives are to obtain information about the hydrologic regime in the surficial aquifer of south central Dade County and about the local movement and dispersal of pollutants, and to use this information to assess the future migration and attenuation of the chloride plume and the possibility of contamination of water withdrawn from the proposed new wellfield.

APPROACH: A digital model will be constructed to represent flow and transport in the area containing the chloride plume. Information used to design the model will include descriptions of rock samples and cores and the results of hydraulic testing now taking place as part of a separate study. Information used to calibrate the model will include the results of a synoptic QW reconnaissance by the USGS in 1979 and a time series of OW data collected by DERM at various sites since 1981. The hydraulic regime will be simulated first, to be followed by chloride transport calculations and analyses to predict future plume movement and assess possible wellfield contamination.

PROGRESS \& SIGNIFICANI RESUIIS: New Project

RLANS FOR THIS YEAR: Study available geologic and hydraulic data and construct simulation model of the flow regime in the study area. Identify further data needs. Modify the model as needed for problem. 